\title{
Phosphate Occurrence and Potential in the Region of Afghanistan, Including Parts of China, Iran, Pakistan, Tajikistan, Turkmenistan, and Uzbekistan
}

By G.J. Orris, Pamela Dunlap, and John C. Wallis

With a section on geophysics by Jeff Wynn

Open-File Report 2015-1121

U.S. Department of the Interior

U.S. Geological Survey 


\section{U.S. Department of the Interior SALLY JEWELL, Secretary}

\section{U.S. Geological Survey Suzette M. Kimball, Acting Director}

U.S. Geological Survey, Reston, Virginia: 2015

For more information on the USGS—-the Federal source for science about the Earth, its natural and living resources, natural hazards, and the environment-visit http://www.usgs.gov or call 1-888-ASK-USGS

For an overview of USGS information products, including maps, imagery, and publications, visit http://www.usgs.gov/pubprod

To order this and other USGS information products, visit http://store.usgs.gov

\footnotetext{
Suggested citation:

Orris, G.J., Dunlap, Pamela, and Wallis, J.C., 2015, Phosphate occurrence and potential in the region of Afghanistan, including parts of China, Iran, Pakistan, Tajikistan, Turkmenistan, and Uzbekistan, with a section on geophysics by Jeff Wynn: U.S. Geological Survey Open-File Report 2015-1121, 70 p., http://dx.doi.org/10.3133/ofr20151121.
}

Any use of trade, product, or firm names is for descriptive purposes only and does not imply endorsement by the U.S. Government.

Although this report is in the public domain, permission must be secured from the individual copyright owners to reproduce any copyrighted material contained within this report. 


\section{Contents}

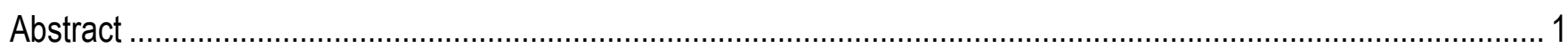

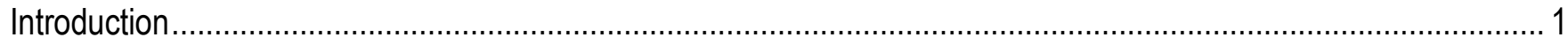

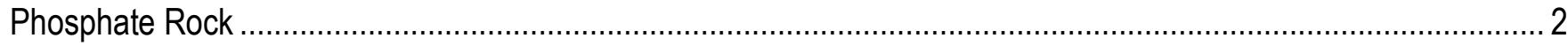

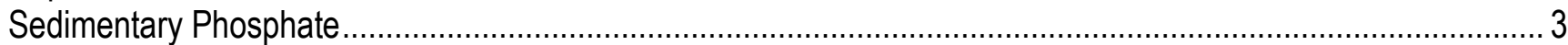

Igneous Sources of Phosphate ………….......................................................................................... 4

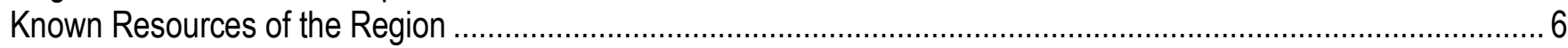

Neoproterozoic-Cambrian Sedimentary Phosphate ...................................................................................

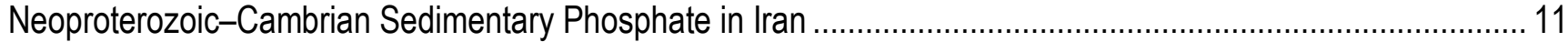

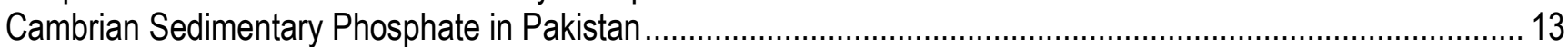

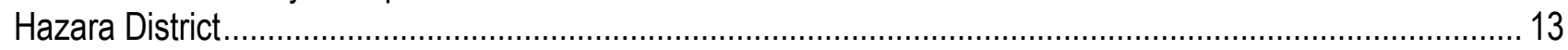

Abbottabad Formation and Hazira Member of the Tarnawai Formation ................................................... 16

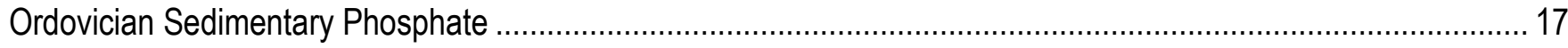

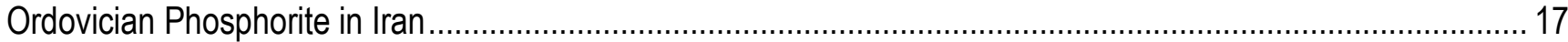

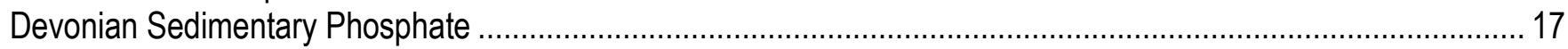

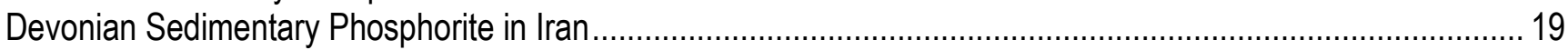

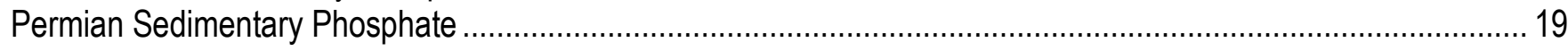

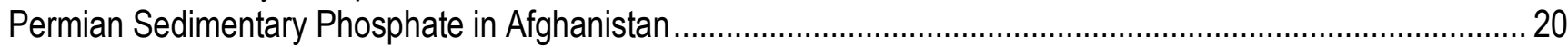

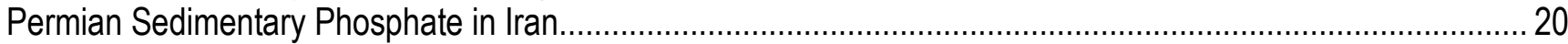

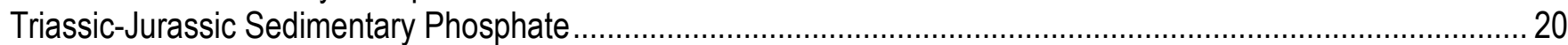

Triassic-Jurassic Sedimentary Phosphate in Iran ............................................................................... 20

Triassic-Jurassic Sedimentary Phosphate in Pakistan ............................................................................ 20

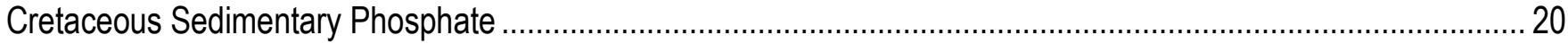

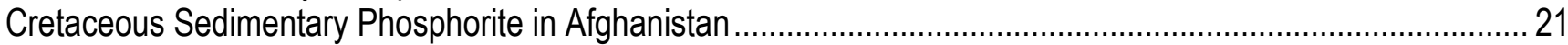

Cretaceous Sedimentary Phosphorite in Iran....................................................................................... 21

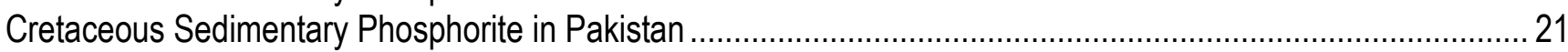

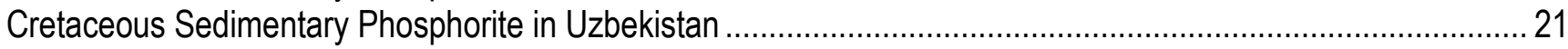

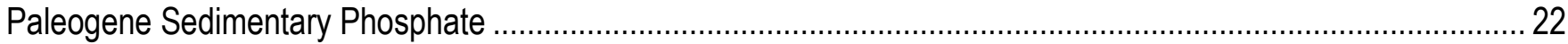

Paleogene Sedimentary Phosphate in Afghanistan .................................................................................. 27

Paleogene Sedimentary Phosphate in Uzbekistan, Tajikistan, and Turkmenistan ............................................. 28

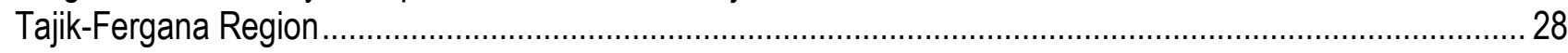

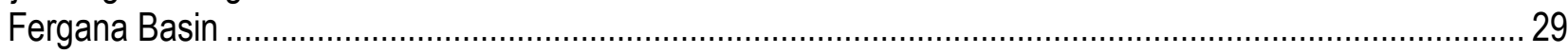

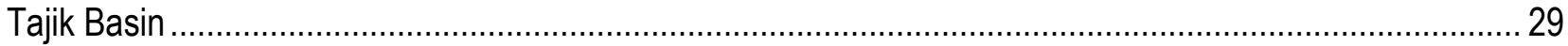

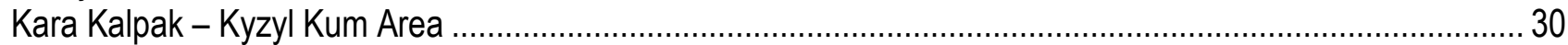

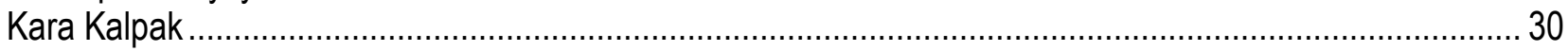

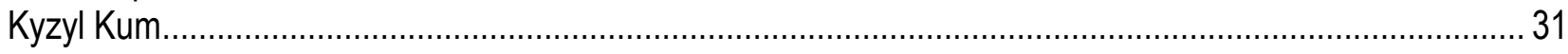

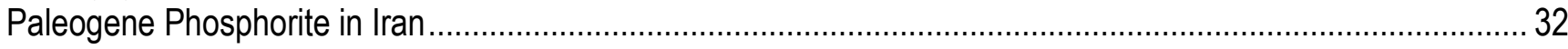

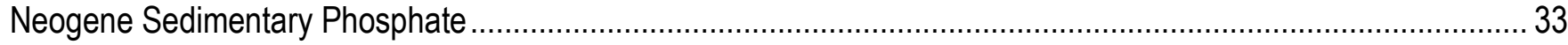

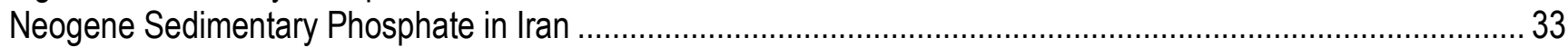

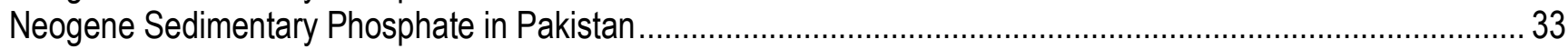

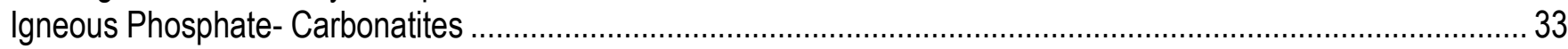

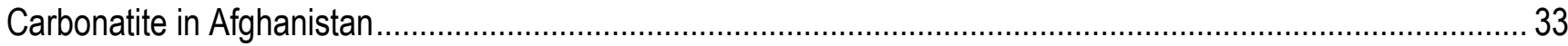

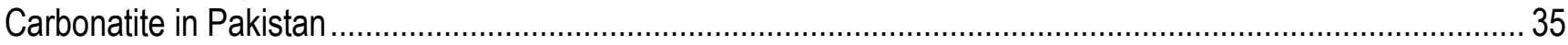

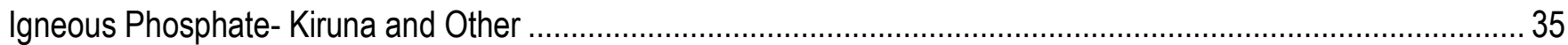

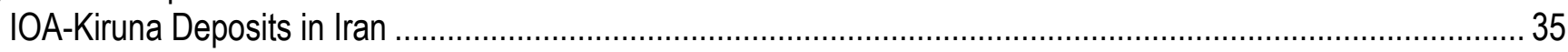

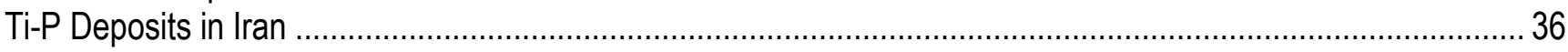




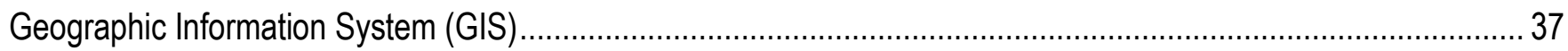

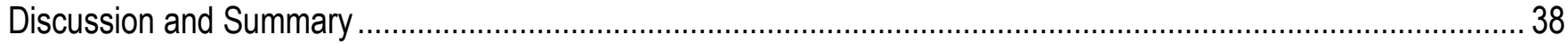

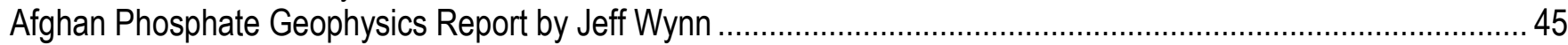

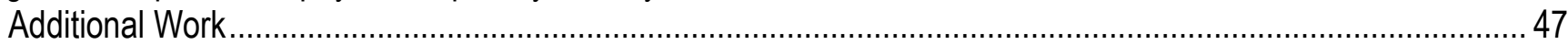

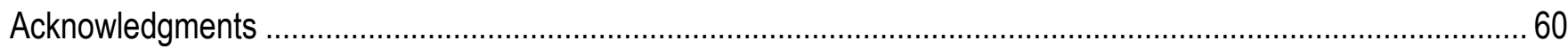

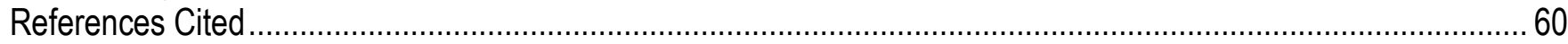

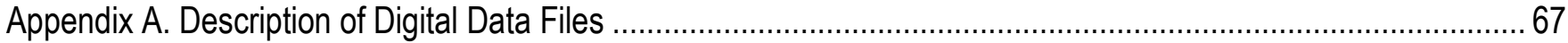

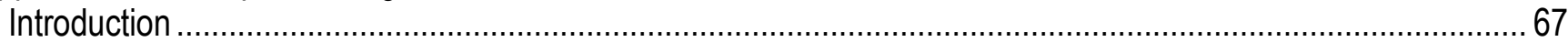

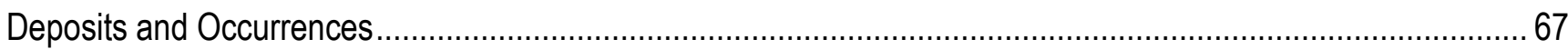

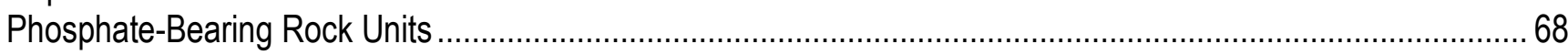

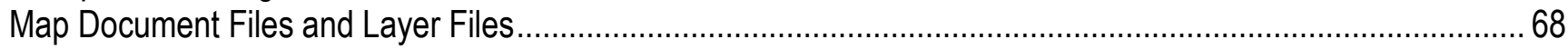

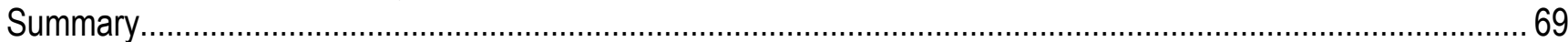

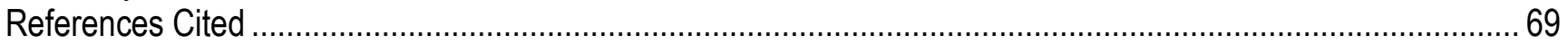

\section{Figures}

1. Distribution of phosphate deposits and occurrences by age relative to similar age sedimentary rocks. .........5

2. A) Percent of total known sedimentary phosphate resources by country and geologic age; B) Percent of total known igneous and sedimentary phosphate resources by country and geologic age................................10

3. Map of the simplified structural zones of Iran...............................................................................12

4. Distribution map of Cambrian sedimentary phosphate deposits and occurrences relative to outcrops of Cambrian sediments in northern Iran............................................................................................13

5. Generalized stratigraphic section of the Soltanieh Formation after Hamdi and others (1989) and Ghorbani

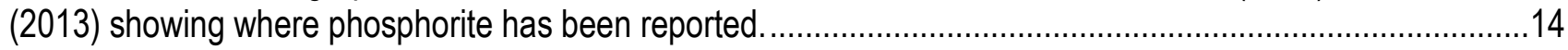

6. Map of the provinces of Pakistan. ………...................................................................................

7. Geologic map of the phosphate district near Abbottabad, Hazara District, Northwest Frontier Province,

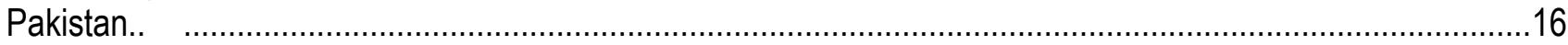

8. Distribution of Ordovician and Devonian sedimentary phosphate in the study area showing outcrops of Ordovician and Devonian sediments. .............................................................................................18

9. Stratigraphic section of the Chichali Formation in the Salt Range .......................................................22

10. Paleogeographical scheme after Akhmetiev and others (2012) showing approximate areas of Late

Paleocene to Early Eocene phosphate deposition within paleo-Tethys Sea basin areas of present day

Uzbekistan and Pakistan. ...........................................................................................................24

11. Index map showing geographic locations and phosphate deposits and occurrences mentioned in the text. 25

12. Map showing the areal distribution of Suzak Formation mudstone beds in overriding thrust sheets. ...........28

13. Stratigraphic sections for the Dzheroi and Tashkura phosphate occurrences (deposits)..............................32

14. Map of the distribution of Paleogene sedimentary phosphate in Iran ......................................................34

15. Schematic stratigraphic sequence of the lithology of the Cambrian Volcanic-Sedimentary Unit (Saghand Formation) at the Esfordi phosphate deposit .....................................................................................

16. Geologic cross section from the northern part of the Afghan High to the Amu Darya River, Afghanistan.....42

17. Geologic cross section from Andkhoy step to the North Afghan High...................................................43

18. Geophysical anomalies that might indicate the presence of phosphate in the near surface relative to the Kotal-i-Sabzak occurrence in Afghanistan.

19. Correlation of uranium and phosphate contents in sediments of the paleo-Tethyan Sea. ............................47

20. Gamma ray log and percent $\mathrm{P}_{2} \mathrm{O}_{5}$ versus depth for the Al Jalamid deposit, Saudi Arabia...........................48 
21. Gravity Recovery and Climate Experiment (GRACE) gravity data overlaid on topography for a part of western Afghanistan 49

22. Magnetic (shaded-relief) data for a part of western Afghanistan...........................................................50

23. Low-pass filtered magnetic data overlaid on topographic contours in part of western Afghanistan. .............51

24. Airborne-sensed potassium data (in percent) overlaid on topography .................................................52

25. Airborne-sensed thorium data (in ppm) draped on topography. .........................................................53

26. Airborne-sensed uranium data (in ppm) draped on topography. .........................................................54

27. Airborne-sensed uranium data (in ppm) overlaid on GRACE gravity data (in mGal). ...............................55

28. Airborne-sensed uranium data (in ppm) overlaid on shaded low-pass magnetics. ...................................56

29. Uranium/potassium ratio data draped on shaded topography. ............................................................57

30. Uranium/thorium ratio data draped on shaded topography..............................................................58

31. A U-Th-K radioelement ternary diagram for west Afghanistan, designed to show each of the three radioelements on the same image

\section{Tables}

1. Identified resources and active mines in the Afghanistan region

2. Thickness and $\mathrm{P}_{2} \mathrm{O}_{5}$ content of some Paleogene phosphorite occurrences in Central Asia. $\mathrm{P}_{2} \mathrm{O} 5$ contents are assumed to be in weight percent, although this was not specified in the sources.

3. Data fields in phosphate sites database.

4. Map sources for lithologies used in study.

5. Potential phosphate-bearing host lithologies compiled and categorized from fourteen 1:500,000- and 1:1,000,000-scale geologic maps.

A1. Identified resources and active mines in the Afghanistan region 


\section{Conversion Factors}

International System of Units to Inch/Pound

\begin{tabular}{|c|c|c|}
\hline Multiply & By & To obtain \\
\hline \multicolumn{3}{|c|}{ Length } \\
\hline centimeter $(\mathrm{cm})$ & 0.3937 & inch (in.) \\
\hline meter $(\mathrm{m})$ & 3.281 & foot $(\mathrm{ft})$ \\
\hline kilometer (km) & 0.6214 & mile (mi) \\
\hline kilometer (km) & 0.5400 & mile, nautical (nmi) \\
\hline meter $(\mathrm{m})$ & 1.094 & yard (yd) \\
\hline \multicolumn{3}{|c|}{ Area } \\
\hline square meter $\left(\mathrm{m}^{2}\right)$ & 0.0002471 & acre \\
\hline square kilometer $\left(\mathrm{km}^{2}\right)$ & 247.1 & acre \\
\hline square meter $\left(\mathrm{m}^{2}\right)$ & 10.76 & square foot $\left(\mathrm{ft}^{2}\right)$ \\
\hline square kilometer $\left(\mathrm{km}^{2}\right)$ & 0.3861 & square mile $\left(\mathrm{mi}^{2}\right)$ \\
\hline \multicolumn{3}{|c|}{ Volume } \\
\hline cubic meter $\left(\mathrm{m}^{3}\right)$ & 35.31 & cubic foot $\left(\mathrm{ft}^{3}\right)$ \\
\hline cubic meter $\left(\mathrm{m}^{3}\right)$ & 1.308 & cubic yard $\left(\mathrm{yd}^{3}\right)$ \\
\hline \multicolumn{3}{|c|}{ Mass } \\
\hline $\operatorname{gram}(\mathrm{g})$ & 0.03527 & ounce, avoirdupois (oz) \\
\hline kilogram (kg) & 2.205 & pound avoirdupois (lb) \\
\hline metric ton per day & 1.102 & ton per day (ton/d) \\
\hline metric ton per year & 1.102 & ton per year (ton/yr) \\
\hline
\end{tabular}

\section{Abbreviations}

ppm parts per million

USGS U.S. Geological Survey 


\title{
Phosphate Occurrence and Potential in the Region of Afghanistan, Including Parts of China, Iran, Pakistan, Tajikistan, Turkmenistan, and Uzbekistan
}

\author{
By G.J. Orris, Pamela Dunlap, and John C. Wallis
}

\begin{abstract}
As part of a larger study, the U.S. Geological Survey undertook a study to identify the potential for phosphate deposits in Afghanistan. As part of this study, a geographic information system was constructed containing a database of phosphate occurrences in Afghanistan and adjacent countries, and a database of potential host lithologies compiled from 1:1,000,000 scale maps. Within Afghanistan, a handful of known occurrences and reports indicate the presence of phosphate in Permian, Cretaceous, and Paleogene sediments and in carbonatite. With the exception of the Khanneshin carbonatite, very little is known about these occurrences. In the countries surrounding Afghanistan, economic phosphate is known to occur in Cambrian, Devonian, and Paleogene sediments and in Kiruna-type Fe-apatite deposits. Many of the host units may extend into Afghanistan or equivalent units may be present. Although the possibility of economic phosphate deposits exist for Afghanistan, the need for detailed exploration for phosphate, the remoteness of some locations, and the probability that a deposit would not be exposed at the surface mean that one or more deposits are not likely to be identified in the near future. Even if a phosphate-bearing deposit is identified in Afghanistan, it is not clear if the probable size, thickness, and grade ranges would allow economic development of the hypothesized resource.
\end{abstract}

\section{Introduction}

This report presents the initial results of an investigation into the potential for deposits of phosphate rock in Afghanistan, where phosphate mineralization is only known to occur in carbonatite at the following sites:

1) Khanneshin carbonatite (Tucker and others, 2011a,b);

2) Loe Shilman carbonatite on the Pakistan-Afghanistan border (Hasan and Asrarullah, 1989);

3) Cretaceous marine sedimentary Kotal-i-Sabzak occurrence in Herat Province (Abdullah and others, 1980);

4) Permian marine sedimentary occurrence in the Darrah-i-Begaw Valley in Badakshan Province (Abdullah and others, 1980); and the

5) Paleogene marine sedimentary phosphate identified in oil and gas drill-holes in the Afghan-Tajik Basin (Klett and others, 2006).

With the exception of the Khanneshin carbonatite, very little information is available for any of the occurrences. The Loe Shilman carbonatite has not been studied on the Afghanistan side of the 
border. Because of the lack of information, this study looked at phosphate deposits and occurrences in countries adjacent to Afghanistan, including Iran, Pakistan, Tajikistan, Turkmenistan, and Uzbekistan to aid in determining what additional types and ages of phosphate deposits might occur in Afghanistan, as well as the potential for these deposits to occur.

Within the expanded study area, economic or sub economic phosphate is known to occur in marine sediments of Neoproterozoic-Cambrian, Devonian, and Paleogene sediments. Additional occurrences have been identified in Ordovician, Permian, Triassic, Jurassic, and Miocene sediments. In addition to phosphate deposits and occurrences associated with carbonatites, phosphate is mined from a Kiruna-type Fe-apatite deposit at Esfordi in Iran. Additional occurrences are associated with alkaline igneous rocks, mafic-ultramafic rocks, and volcanic rocks.

Data for more than 400 deposits (sites with known production or resources-reserves with tonnage and grade) and occurrences of phosphate in the study area were compiled into a database. In addition, the host rocks for the known deposits and occurrences, and potential host rocks for similar occurrences were compiled from 1:1,000,000 scale geologic maps for each country or from Sovietera 1:1,000,000 scale geologic quadrangle maps. These databases were combined into a geographic information system (GIS) that accompanies this report.

This report provides an overview of the types and distribution of phosphate deposits within the specified study area in the region of Afghanistan. Sedimentary phosphate deposits are discussed, by country, within geologic periods and eras containing known occurrences or deposits. This is followed by descriptions of the types of igneous-related deposits that have been documented within the area. A description of the GIS databases and files that are included in this report is followed by a discussion of the potential for the discovery of economic phosphate deposits in Afghanistan. Finally, a section on the regional geophysics for northwestern Afghanistan is provided by Jeff Wynn.

\section{Phosphate Rock}

Phosphorus is an element broadly distributed in nature that forms minerals in a wide variety of crustal rocks. Phosphate rock is utilized worldwide for the manufacture of phosphoric acid and various types of chemical fertilizers. It is one of the world's most widely traded minerals. China, the United States, and Morocco are the major producers (Jasinski, 2014) and developed countries such as those in North America, Europe, and the Pacific Rim tend to be major end users.

Phosphorite and phosphate rock are imprecise terms for rocks that contain relatively high amounts of phosphate minerals and that, in some literature, are used interchangeably. However, phosphorite is most commonly used when referring to sediment-hosted deposits and this report follows that usage.

In 1989, Notholt and others (1989a) noted that commercial phosphate deposits might average as little as 3.8 percent $\mathrm{P}_{2} \mathrm{O}_{5}$ (phosphate grade reported as phosphorous pentoxide). Most economic deposits have higher grades, but average grade can vary with the type and location of the deposit. Although phosphate is produced from several apatite-bearing igneous deposits throughout the world and a small percentage is produced from guano deposits, sedimentary phosphate deposits are the most common and are known to occur in more than 80 countries (Orris and Chernoff, 2004). More than 75 percent of economic phosphate production is from sedimentary deposits and sedimentary phosphate deposits contain the largest proportion of the world's reserves relative to other deposit types (Cook and others, 1990).

More detailed classification of sedimentary phosphate rock deposits remains elusive. Despite the abundant descriptive literature for sedimentary phosphate deposits, many of the deposits have 
complex depositional and post-depositional histories and features that can make classification of many deposits into a specific subcategory difficult.

\section{Sedimentary Phosphate}

Sedimentary phosphate deposits occur on every continent, including Antarctica (Cathcart and Schmidt, 1977), and range in age from Early Proterozoic to Holocene (Orris and Chernoff, 2004). Several major phosphogenic events have been recognized: (1) a Late Proterozoic-Cambrian depositional event, with deposits largely found in Central and South Asia; (2) a Permian event represented by deposits in North America; (3) a Jurassic to Early Cretaceous set of deposits in eastern Europe; (4) a Late Cretaceous to Eocene event with deposits in North Africa, the Middle East, and, to a lesser extent, Central Asia; and (5) a Miocene depositional event represented by the deposits found in the southeastern part of the United States.

Riggs (1980) grouped the depositional environments of sedimentary phosphate deposits into three categories: intra-plate marine deposits, deposits associated with active plate boundaries, and insular deposits. Intra-plate depositional environments include shelves, platforms and basins (including marginal and intracratonic sedimentary troughs), plateaus and seamounts, and environments in which destructive sedimentary processes operate. The active plate boundary environment includes marine and lacustrine systems. Insular environments include guano, as well as replacement and residual deposits resulting from chemical and (or) mechanical weathering.

Most economic sedimentary phosphate deposits are of marine origin and were formed in active marine basins, epicontinental seas, shelf environments, or intracratonic sag basins (Orris and Chernoff, 2004). Marine upwelling in basins along active continental margins localizes deposition of phosphorite in active margins or epicontinental seas. Deposits that form in these environments tend to be extensive in area and composed of pelletal phosphate. These deposits also tend to have relatively high $\mathrm{P}_{2} \mathrm{O}_{5}$ contents throughout most of their extent (Cook, 1976), and they are commonly associated with organic-rich argillaceous sedimentary rocks, chert, dolostone and volcanic materials (Mosier, 1986a).

Shelf and platform phosphate deposits tend to be less extensive than deposits associated with active continental margins, although nodular phosphate in these environments may cover very large areas. These deposits are commonly hosted by carbonate and sandstone and, in places, glauconite, diatomite, or coquina. These deposits are commonly found on the flanks of structural highs (Mosier, 1986b).

Other types of sedimentary phosphate deposits are locally or regionally important. These include modern sea floor deposits and deposits formed from the replacement of carbonates and other rocks on seamounts and submarine plateaus and ridges. Sedimentary phosphate deposits may also form from cementation and replacement of carbonate on submarine highs where there is an organicrich environment (Orris and Chernoff, 2004). Some continental shelf and slope phosphates form in environments where organic matter is not preserved in the sediments (Benninger and Hein, 2000).

Favorable paleoceanographic, paleogeographic, and paleoclimatic conditions are needed to form sedimentary phosphate deposits and development is enhanced where there is an influx of nutrient-rich water into a shallow marine environment (Orris and Chernoff, 2004). One of the most important factors in the development of economic phosphate deposit is the avoidance of depositional dilution from clastics and the formation of carbonates. In addition, formation of phosphate deposits requires a source of phosphate, chemical and regional structural conditions suitable for entrapping the phosphate, a slow sedimentation rate, and stable basin conditions. 
Phosphate can be concentrated by currents and upwelling by density plumes from rivers, or by biota in photic zones. Upwelling is one of the most commonly cited phosphate concentration mechanisms for many deposits (Orris and Chernoff, 2004) and is also commonly linked with continental margins and mid- to low-latitudes. It should be noted that high biologic productivity is important, but not essential, to phosphate deposition (Hein and others, 1993).

Marine transgressions are also commonly invoked as a mechanism of phosphate concentration. Rising sea levels lead to higher biologic activity during flooding of shelf environments. Marine transgressions may also raise the carbonate compensation depth in seas, where the carbonate compensation depth is the depth below which all calcareous material is dissolved. This could aid phosphate deposition in shallow water by removing a deep-sea phosphate sink (Mitchell and Garson, 1981).

Within Afghanistan and adjacent countries, marine sedimentary phosphate deposits and occurrences are present in Late Proterozoic-Early Cambrian, Ordovician, Devonian, Permian, Triassic, Jurassic, Cretaceous, Paleogene, and Miocene sedimentary sequences (figs. 1, 2). Sedimentary phosphate deposit has been identified in Afghanistan in Cretaceous sediments at one location and in Permian sediments at a different location. In addition, widespread phosphate has been identified in Paleogene sedimentary rocks in southern Uzbekistan, Tajikistan, and Turkmenistan, and reported in drill holes in Afghan-Tajik Basin sediments. Phosphate-bearing strata of other ages may also be present in Afghanistan, although the potential for economic deposits is unknown and problematic based on the data available at this time.

\section{Igneous Sources of Phosphate}

About 18 percent of phosphate production (Notholt, 1989a) is derived from apatite-group-bearing igneous rocks and their weathered equivalents. These deposits are commonly associated with carbonatites and alkaline igneous intrusions. Fluorapatite is the predominant phosphate mineral in unaltered deposits. Francolite occurs as a secondary mineral in supergene phases and residually enriched deposits. Phosphate deposits hosted in igneous rocks are commonly low grade compared to sedimentary phosphate deposits and beneficiation can be expensive. On the other hand, these types of phosphate deposits may be of interest because other commodities of economic interest, such as rare earth elements or niobium, are frequently present (Cook and others, 1990). Notholt and others (1989) estimated that world resources of igneous phosphate rock totaled about 5,500 million metric tons (Mt) at that time. Phosphate has been identified at the Khanneshin Carbonatite in southwestern Afghanistan, as well as in the Loe Shilman Carbonatite on the border of Pakistan and Afghanistan (Kogarko and others, 1995; fig. 1); these deposits are described more fully later in this manuscript and in the GIS. In addition, a cluster of Kiruna-type iron-apatite igneous deposits is known in eastern Iran; the deposit at Esfordi is currently being mined for phosphate (Jami, 2005). 


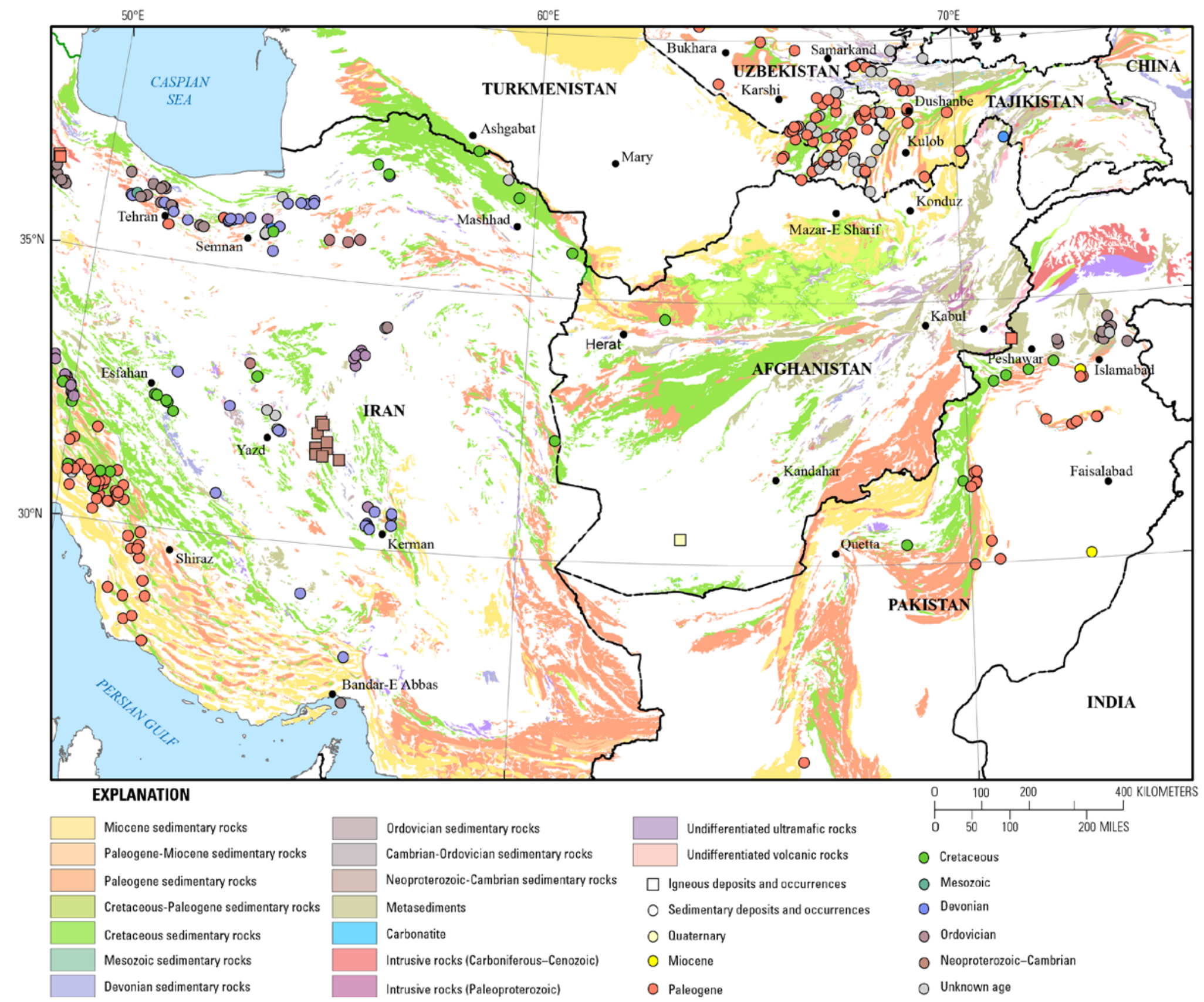

Figure 1. Distribution of phosphate deposits and occurrences by age relative to similar age sedimentary rocks. 


\section{Known Resources of the Region}

There are several mines producing phosphate in the study area. However, for some sites, it was difficult to determine if they were active or historical producers because of conflicting information. The Esfordi igneous Fe-apatite deposit in Iran has been producing phosphate for some years, as has the Kakul mine in Pakistan. A list of phosphate deposits with defined reserves and (or) sites that are currently producing phosphate or have produced phosphate in the past are shown in table 1 . The percentage of the total identified sedimentary phosphate resources that are found in sedimentary rocks of a specified geologic age are shown by country in figure $2 A$. Figure $2 B$ shows the same as a percentage of the total identified phosphate resources in sedimentary and igneous host rocks. In the four countries with this information available, the identified resources and reserves are dominantly Paleogene sedimentary phosphate.

\section{Neoproterozoic-Cambrian Sedimentary Phosphate}

Within the study area, there are more than 70 deposits and occurrences of lower Cambrian-age marine phosphorite. Neoproterozoic- to Cambrian-age phosphate deposits can be found throughout much of Europe and Asia, including China, Mongolia, Kazakhstan, and Russia, as well as in Iran and Pakistan (Shields and others, 2000). It is not clear if phosphogenesis of this period is related to upwelling or other paleoceanographic characteristics, or if it is related to changes in the global phosphorus budget. Shields and others (2000) point out that this episode of phosphogenesis does correspond with the increase in metazoan diversity of the Cambrian explosion and can also be linked to a period of increased continental weathering.

In China, phosphate deposition in this period is linked to major marine transgressions. Similarly, transgression of the lower Cambrian sea over Proterozoic rocks in the Alborz region of Iran (fig. 3) that extended into Azerbaijan resulted in the deposition of phosphate-bearing shale, limestone and dolomite (Ghorbani, 2013). These Early Cambrian sediments conformably overlie Ediacaran dolomites.

Table 1. Identified resources and active mines in the Afghanistan region.

$[?=$ uncertain if production or if production is active or in the past; Mt, million metric tons; Bt, billion metric tons; \%, percent]

\begin{tabular}{|c|c|c|c|c|c|}
\hline Site Name & $\begin{array}{c}\text { Deposit } \\
\text { Type }^{1}\end{array}$ & $\begin{array}{c}\text { Age of } \\
\text { Mineralization }\end{array}$ & Production? & Resources/Reserves & Reference \\
\hline IRAN & & & & & \\
\hline Aghkand-seidkand & $\mathrm{S}$ & Cambrian & & $17 \mathrm{Mt} @ 12.7 \% \mathrm{P}_{2} \mathrm{O}_{5}$ & $\begin{array}{l}\text { Iran Geological Survey } \\
\text { (2013a) } \\
\text { Iran Geological Survey }\end{array}$ \\
\hline Bangestan 2 & $\mathrm{~S}$ & Eocene & & $30 \mathrm{Mt} @ 12 \% \mathrm{P}_{2} \mathrm{O}_{5}$ & (2013a) \\
\hline Behbehan & $\mathrm{S}$ & Paleocene & & $165 \mathrm{Mt} @ 20 \% \mathrm{P}_{2} \mathrm{O}_{5}$ & $\begin{array}{l}\text { Notholt (1994) } \\
\text { Iran Geological Survey }\end{array}$ \\
\hline Chahgaz & I & Cambrian & & $8 \mathrm{Mt} @ 4.5 \% \mathrm{P}_{2} \mathrm{O}_{5}$ & $\begin{array}{l}(2013 a) \\
\text { Iran Geological Survey }\end{array}$ \\
\hline Chalmish & $\mathrm{S}$ & Upper Devonian & & $8.5 \mathrm{Mt} @ 10.33 \% \mathrm{P}_{2} \mathrm{O}_{5}$ & $\begin{array}{l}(2013 a) \\
\text { Iran Geological Survey }\end{array}$ \\
\hline $\begin{array}{l}\text { Chashin } \\
\text { Cheshmeh }\end{array}$ & $\mathrm{S}$ & Cambrian & & $4 \mathrm{Mt} @ 5.5 \% \mathrm{P}_{2} \mathrm{O}_{5}$ & $\begin{array}{l}(2013 a) \\
\text { Iran Geological Survey }\end{array}$ \\
\hline $\begin{array}{l}\text { mesnmen } \\
\text { mohammad }\end{array}$ & $\mathrm{S}$ & Ordovician & & $\begin{array}{l}6.2 \mathrm{Mt} @ 5 \% \mathrm{P}_{2} \mathrm{O}_{5} \\
1.13 \mathrm{Mt} @ 7.5 \% \mathrm{P}_{2} \mathrm{O}_{5}\end{array}$ & $\begin{array}{l}\text { Iran Geological Survey } \\
\text { (2013a) }\end{array}$ \\
\hline Dahoieh (Zarand) & $\mathrm{S}$ & Ordovician & & probable & Qorbani and Kani (2005) \\
\hline
\end{tabular}




\begin{tabular}{|c|c|c|c|c|c|}
\hline Site Name & $\begin{array}{l}\text { Deposit } \\
\text { Type }^{1}\end{array}$ & $\begin{array}{c}\text { Age of } \\
\text { Mineralization }\end{array}$ & Production? & Resources/Reserves & Reference \\
\hline Dalir & $\mathrm{S}$ & Cambrian & & $\begin{array}{l}23 \mathrm{Mt} @ 11.5 \% \mathrm{P}_{2} \mathrm{O}_{5}, \\
\text { probable }\end{array}$ & Ghorbani (2013) \\
\hline Darreh-e- & & & & $1.2 \mathrm{Mt} @ 8.5-11.48 \%$ & Iran Geological Survey \\
\hline Goldredin & $\mathrm{S}$ & Cambrian & & $\mathrm{P}_{2} \mathrm{O}_{5}$ & (2013a) \\
\hline Dehmolla & $\mathrm{S}$ & Upper Devonian & & $\begin{array}{l}11.7 \mathrm{Mt} @ 10 \% \mathrm{P}_{2} \mathrm{O}_{5} \\
17 \mathrm{Mt} \text { proven + } 22 \mathrm{Mt}\end{array}$ & $\begin{array}{l}\text { Iran Geological Survey } \\
\text { (2013a) }\end{array}$ \\
\hline Esfordi & I & Cambrian & Yes, active & probable@13.9\% $\mathrm{P}_{2} \mathrm{O}_{5}$ & $\begin{array}{l}\text { Esfordi Phosphate (2013) } \\
\text { Iran Geological Survey }\end{array}$ \\
\hline Firuzabad & $\mathrm{S}$ & Cambrian & & $14 \mathrm{Mt} @ 8 \% \mathrm{P}_{2} \mathrm{O}_{5}$ & (2013a) \\
\hline Firuzkuh & $\mathrm{S}$ & Upper Devonian & & $56 \mathrm{Mt} @ 12 \% \mathrm{P}_{2} \mathrm{O}_{5}$ & $\begin{array}{l}\text { Ghorbani (2013) } \\
\text { Iran Geological Survey }\end{array}$ \\
\hline Gaduk & $\mathrm{S}$ & Upper Devonian & & $30.5 \mathrm{Mt} @ 12 \% \mathrm{P}_{2} \mathrm{O}_{5}$ & $\begin{array}{l}(2013 a) \\
\text { Mehdilo and Irannajad }\end{array}$ \\
\hline Gara-aghaj & I & Permian? & & $102 \mathrm{Mt} @ 2.3 \% \mathrm{P}_{2} \mathrm{O}_{5}$ & $\begin{array}{l}(2012) \\
\text { Jran Gelogical Survey }\end{array}$ \\
\hline Jeirud & $\mathrm{S}$ & Upper Devonian & Yes, active & definite + probable & $(2013 b)$ \\
\hline Kalmard & $\mathrm{S}$ & Ordovician & & $6.2 \mathrm{Mt} @ 5 \% \mathrm{P}_{2} \mathrm{O}_{5}$ & $\begin{array}{l}\text { Qorbani and Kani (2005) } \\
\text { Iran Geological Survey }\end{array}$ \\
\hline Kikuh & $\mathrm{S}$ & Cambrian & & $14 \mathrm{Mt} @ 8.5 \% \mathrm{P}_{2} \mathrm{O}_{5}$ & $\begin{array}{l}\text { (2013a) } \\
\text { Iran Geological Survey }\end{array}$ \\
\hline $\begin{array}{l}\text { Kuh-e-Alimak } \\
\text { Kuh-e-Kaftari }\end{array}$ & $\begin{array}{l}\mathrm{S} \\
\mathrm{S}\end{array}$ & $\begin{array}{l}\text { Ordovician } \\
\text { Cambrian }\end{array}$ & & $6.2 \mathrm{Mt} @ 5 \% \mathrm{P}_{2} \mathrm{O}_{5}$ & $(2013 a)$ \\
\hline Kuh-e-Kumeh & $\mathrm{S}$ & Oligocene & & $\begin{array}{l}\text { probable } \\
\text { a }\end{array}$ & Qorbani and Kani (2005) \\
\hline Kuh-e-Moug & $\mathrm{S}$ & Eocene & & $\begin{array}{l}22 \mathrm{Mt} @ 9.8 \% \mathrm{P}_{2} \mathrm{O}_{5}, \\
\text { probable }\end{array}$ & $\begin{array}{l}\text { Iran Geological Survey } \\
\text { (2013a) }\end{array}$ \\
\hline Kuh-e-Namak & $\mathrm{S}$ & Paleocene & & $\begin{array}{l}24 \mathrm{Mt} @ 8.2 \% \mathrm{P}_{2} \mathrm{O}_{5} \\
10.6 \mathrm{Mt} @ 11.2 \% \mathrm{P}_{2} \mathrm{O}_{5},\end{array}$ & Qorbani and Kani (2005) \\
\hline Kuh-e-Rish & $\mathrm{S}$ & Eocene & & $\begin{array}{l}\text { probable } \\
17 \mathrm{Mt} @ 12.5 \% \mathrm{P}_{2} \mathrm{O}_{5}\end{array}$ & Qorbani and Kani (2005) \\
\hline Kuh-e-Safid & $\mathrm{S}$ & Eocene & & $\begin{array}{l}\text { probable } \\
13.5 \mathrm{Mt} @ 0.34-8.07 \%\end{array}$ & $\begin{array}{l}\text { Qorbani and Kani (2005) } \\
\text { Iran Geological Survey }\end{array}$ \\
\hline Kuh-e-Siah & $\mathrm{S}$ & Eocene & & $\begin{array}{l}\mathrm{P}_{2} \mathrm{O}_{5} \\
56 \mathrm{Mt} @ 8.5 \% \mathrm{P}_{2} \mathrm{O}_{5},\end{array}$ & Orboni and Kani (2005) \\
\hline Kur Mowj & $\mathrm{S}$ & Paleogene? & & probable & $\begin{array}{l}\text { Qorbani and Kani (2005) } \\
\text { Iran Geological Survey }\end{array}$ \\
\hline Lakkeh Siah & $\mathrm{S}$ & Cambrian & & $5 \mathrm{Mt} @ 5.5 \% \mathrm{P}_{2} \mathrm{O}_{5}$ & $\begin{array}{l}\text { (2013a) } \\
\text { Iran Geological Survey }\end{array}$ \\
\hline Lalun & I & Upper Devonian & Under & $6 \mathrm{Mt} @ 13.7-20.7 \% \mathrm{P}_{2} \mathrm{O}_{5}$ & $(2013 a)$ \\
\hline Lar & $\mathrm{S}$ & Eocene & $\begin{array}{l}\text { developm } \\
\text { ent }\end{array}$ & $\begin{array}{l}210 \mathrm{Mt} @ 10.5 \% \mathrm{P}_{2} \mathrm{O}_{5}, \\
\text { estimated }\end{array}$ & $\begin{array}{l}\text { Gholizadeh and others (2009) } \\
\text { Iran Geological Survey }\end{array}$ \\
\hline Molladagh & $\mathrm{S}$ & Cambrian & & $9 \mathrm{Mt} @ 4.27 \% \mathrm{P}_{2} \mathrm{O}_{5}$ & $\begin{array}{l}(2013 a) \\
\text { Iran Geological Survey }\end{array}$ \\
\hline Morgdar & I & Upper Devonian & & $2.3 \mathrm{Mt} @ 7.8 \% \mathrm{P}_{2} \mathrm{O}_{5}$ & $\begin{array}{l}\text { (2013a) } \\
\text { Iran Geological Survey }\end{array}$ \\
\hline Paghaleh & $\mathrm{S}$ & Upper Devonian & & $23 \mathrm{Mt} @ 9.42 \% \mathrm{P}_{2} \mathrm{O}_{5}$ & $\begin{array}{l}(2013 a) \\
\text { Iran Geological Survey } \\
(2013 a)\end{array}$ \\
\hline Rizrud & $\mathrm{S}$ & Paleocene & & $160 \mathrm{Mt} @ 8.25 \% \mathrm{P}_{2} \mathrm{O}_{5}$ & Qorbani and Kani (2005) \\
\hline
\end{tabular}




\begin{tabular}{|c|c|c|c|c|c|}
\hline Site Name & $\begin{array}{c}\text { Deposit } \\
\text { Type }^{1} \\
\end{array}$ & $\begin{array}{c}\text { Age of } \\
\text { Mineralization }\end{array}$ & Production? & Resources/Reserves & Reference \\
\hline Sheik Habil & $\mathrm{S}$ & $\begin{array}{l}\text { Cretaceous- } \\
\text { Eocene }\end{array}$ & & $\begin{array}{l}\text { probable } \\
1 \mathrm{Mt} @ 22 \% \mathrm{P}_{2} \mathrm{O}_{5}, \\
\text { probable } \\
12 \mathrm{Mt} 222.5 \% \mathrm{P}_{2} \mathrm{O}_{5}+34\end{array}$ & Qorbani and Kani (2005) \\
\hline Shemsek & $\mathrm{S}$ & Upper Devonian & & $\mathrm{Mt} @ 11.4 \% \mathrm{P}_{2} \mathrm{O}_{5}$ & Salehi (1989) \\
\hline Soltanieh & $\mathrm{S}$ & Cambrian & & $30 \mathrm{Mt} @ 12 \% \mathrm{P}_{2} \mathrm{O}_{5}$ & $\begin{array}{l}\text { Notholt (1994) } \\
\text { Iran Geological Survey }\end{array}$ \\
\hline Valiabad & $\mathrm{S}$ & Cambrian & & $3.2 \mathrm{Mt} @ 8 \% \mathrm{P}_{2} \mathrm{O}_{5}$ & $\begin{array}{l}\text { (2013a) } \\
\text { Iran Geological Survey }\end{array}$ \\
\hline Valian & $\mathrm{S}$ & Cambrian & & $0.6 \mathrm{Mt} @ 10.9 \% \mathrm{P}_{2} \mathrm{O}_{5}$ & (2013a) \\
\hline Zanjan & $\mathrm{S}$ & $\begin{array}{l}\text { Cambrian } \\
\text { Paleocene- }\end{array}$ & & $12 \mathrm{Mt}$ probable & $\begin{array}{l}\text { Qorbani and Kani (2005) } \\
\text { Iran Geological Survey }\end{array}$ \\
\hline Zaravard & $\mathrm{S}$ & Eocene & & $23.5 \mathrm{Mt} @ 7.2 \% \mathrm{P}_{2} \mathrm{O}_{5}$ & $\begin{array}{l}\text { (2013a) } \\
\text { Iran Geological Survey }\end{array}$ \\
\hline Zarigan & $\mathrm{S}$ & Cambrian? & & $5 \mathrm{Mt} @ 3 \% \mathrm{P}_{2} \mathrm{O}_{5}$ & (2013a) \\
\hline PAKISTAN & & & & & \\
\hline $\begin{array}{l}\text { Banda Pir Khan } \\
\text { Batkanala }\end{array}$ & $\begin{array}{l}\mathrm{S} \\
\mathrm{S}\end{array}$ & $\begin{array}{l}\text { Cambrian } \\
\text { Cambrian }\end{array}$ & $\begin{array}{l}\text { Yes, active } \\
\text { Yes, active }\end{array}$ & & $\begin{array}{l}\text { Sabiha-Javied and others } \\
\text { (2009) }\end{array}$ \\
\hline Dalola & $\mathrm{S}$ & Cambrian & & $\begin{array}{l}2.3 \mathrm{Mt} @ 15-18 \% \mathrm{P}_{2} \mathrm{O}_{5} \\
\text { proven }+6.9 \mathrm{Mt} @ 9- \\
25 \% \mathrm{P}_{2} \mathrm{O}_{5}, \text { probable } \\
2.452 \mathrm{Mt} \\
\text { measured+indicated + } \\
1.48 \mathrm{Mt} \text { inferred } @\end{array}$ & Hasan (1986) \\
\hline Eastern & $\mathrm{S}$ & Cambrian & & $\begin{array}{c}25.8 \% \mathrm{P}_{2} \mathrm{O}_{5} \\
0.7 \mathrm{Mt} @ 29 \% \mathrm{P}_{2} \mathrm{O}_{5}\end{array}$ & Ishaque and Ahmad (1987) \\
\hline Kakul & $\mathrm{S}$ & Cambrian & Yes, active & measured + indicated & Appleton and Notholt (2002) \\
\hline Kaludi Bandi & $\mathrm{S}$ & Cambrian & & 8.6 Mt @27\% $\mathrm{P}_{2} \mathrm{O}_{5}$ & Hasan (1986) \\
\hline Lagarban & $\mathrm{S}$ & Cambrian & & $\begin{array}{l}\text { 7.5 Mt recoverable } \\
\text { 2.088 Mt } \\
\text { measured+indicated + } \\
0.261 \mathrm{Mt} \text { inferred } @\end{array}$ & Appleton and Notholt (2002) \\
\hline Lagarban South & $\mathrm{S}$ & Cambrian & & $25.8 \% \mathrm{P}_{2} \mathrm{O}_{5}$ & Ishaque and Ahmad (1987) \\
\hline Lambidogi & $\mathrm{S}$ & Cambrian & historic? & & \\
\hline Oatkanala & $\mathrm{S}$ & Cambrian & Yes, active & $\begin{array}{l}0.879 \mathrm{Mt} \text { indicated }+ \\
\text { inferred } \\
1.9 \mathrm{Mt} 10-25 \% \mathrm{P}_{2} \mathrm{O}_{5},\end{array}$ & Ishaque and Ahmad (1987) \\
\hline Sirbun Hill & $\mathrm{S}$ & Cambrian & & $\begin{array}{l}\text { probable } \\
0.66 \mathrm{Mt} \\
\text { measured+indicated @ }\end{array}$ & Hasan (1986) \\
\hline Southern & $\mathrm{S}$ & Cambrian & & $\begin{array}{l}26.4 \% \mathrm{P}_{2} \mathrm{O}_{5} \\
1.009 \mathrm{Mt} \\
\text { measured+indicated + } \\
1.894 \mathrm{Mt} \text { inferred @ }\end{array}$ & Ishaque and Ahmad (1987) \\
\hline Tarnawai & $\mathrm{S}$ & Cambrian & & $25.6 \% \mathrm{P}_{2} \mathrm{O}_{5}$ & Ishaque and Ahmad (1987) \\
\hline \multicolumn{6}{|l|}{$\begin{array}{l}\text { PAKISTAN, } \\
\text { AFGHANISTAN }\end{array}$} \\
\hline Loe Shilman & $\mathrm{C}$ & Oligocene & & $\begin{array}{c}59 \mathrm{Mt} @ 4.4 \% \mathrm{P}_{2} \mathrm{O}_{5} \text { at } \\
\text { surface; } 142 \mathrm{Mt} @ \\
5.5 \% \mathrm{P}_{2} \mathrm{O}_{5} \text { subsurface }\end{array}$ & Hasan and Asrarullah (1989) \\
\hline
\end{tabular}




\begin{tabular}{|c|c|c|c|c|c|}
\hline Site Name & $\begin{array}{l}\text { Deposit } \\
\text { Type }^{1}\end{array}$ & $\begin{array}{c}\text { Age of } \\
\text { Mineralization }\end{array}$ & Production? & Resources/Reserves & Reference \\
\hline \multicolumn{6}{|l|}{ TAJIKISTAN } \\
\hline Panjakent & $\mathrm{S}$ & Eocene & & $\begin{array}{l}2 \mathrm{Bt} @ 5 \% \text { P2O5, } \\
\text { estimated }\end{array}$ & Popov and others (1982) \\
\hline Rivat & $\mathrm{S}$ & Eocene & & $0.116 \mathrm{Mt}, \mathrm{C} 1$ & Popov and others (1982) \\
\hline \multicolumn{6}{|l|}{ UZBEKISTAN } \\
\hline Akbel & $\mathrm{S}$ & Paleocene & & $0.18 \mathrm{Mt} \mathrm{P}_{2} \mathrm{O}_{5}, \mathrm{P} 1$ & $\begin{array}{l}\text { Uzbekistan State Committee } \\
\text { (2011) }\end{array}$ \\
\hline Ayakkuduk & $\mathrm{S}$ & Eocene & & $16.1 \mathrm{Mt} @ 20.6 \% \mathrm{P}_{2} \mathrm{O}_{5}$ & $\begin{array}{l}\text { Uzbekistan State Committee } \\
\text { (2011) }\end{array}$ \\
\hline Aznek & $\mathrm{S}$ & Eocene & & $26.9 \mathrm{Mt} @ 18.3 \% \mathrm{P}_{2} \mathrm{O}_{5}$ & $\begin{array}{l}\text { Uzbekistan State Committee } \\
\text { (2011) }\end{array}$ \\
\hline Balakarak & $\mathrm{S}$ & Paleocene & & $51.9 \mathrm{Mt}, \mathrm{C} 2$ & $\begin{array}{l}\text { Uzbekistan State Committee } \\
(2011) \\
\text { Uzbekistan State Committee }\end{array}$ \\
\hline Djeroi Yuzhny & $\mathrm{S}$ & Eocene & & $84 \mathrm{Mt} @ 19.2 \% \mathrm{P}_{2} \mathrm{O}_{5}$ & $\begin{array}{l}\text { (2011) } \\
\text { Navoi Mining \& }\end{array}$ \\
\hline Dzheroi-Sardara & $\mathrm{S}$ & Eocene & Yes, active & $303.6 \mathrm{Mt} @ 19 \% \mathrm{P}_{2} \mathrm{O}_{5}$ & $\begin{array}{l}\text { Metallurgical Combinat } \\
\text { (2013) } \\
\text { Uzbekistan State Committee }\end{array}$ \\
\hline Dzhetymtau & $\mathrm{S}$ & Eocene & & $50.2 \mathrm{Mt} @ 20.2 \% \mathrm{P}_{2} \mathrm{O}_{5}$ & $\begin{array}{l}\text { (2011) } \\
\text { Uzbekistan State Committee }\end{array}$ \\
\hline Khodzhakul & $\mathrm{S}$ & Paleogene & & $0.886 \mathrm{Mt}, \mathrm{P} 1+\mathrm{P} 2$ & $(2011)$ \\
\hline Kurukkuduk & $\mathrm{S}$ & Eocene & & $90.1 \mathrm{Mt} @ 19.2 \% \mathrm{P}_{2} \mathrm{O}_{5}$ & $\begin{array}{l}\text { Uzbekistan State Committee } \\
\text { (2011) }\end{array}$ \\
\hline Tashkura & $\mathrm{S}$ & Eocene & Yes, active & $129 \mathrm{Mt} @ 44.7 \% \mathrm{P}_{2} \mathrm{O}_{5}$ & Levine (1997) \\
\hline
\end{tabular}

${ }^{1} \mathrm{C}=$ carbonatite, $\mathrm{I}=$ igneous, $\mathrm{S}=$ sedimentary 

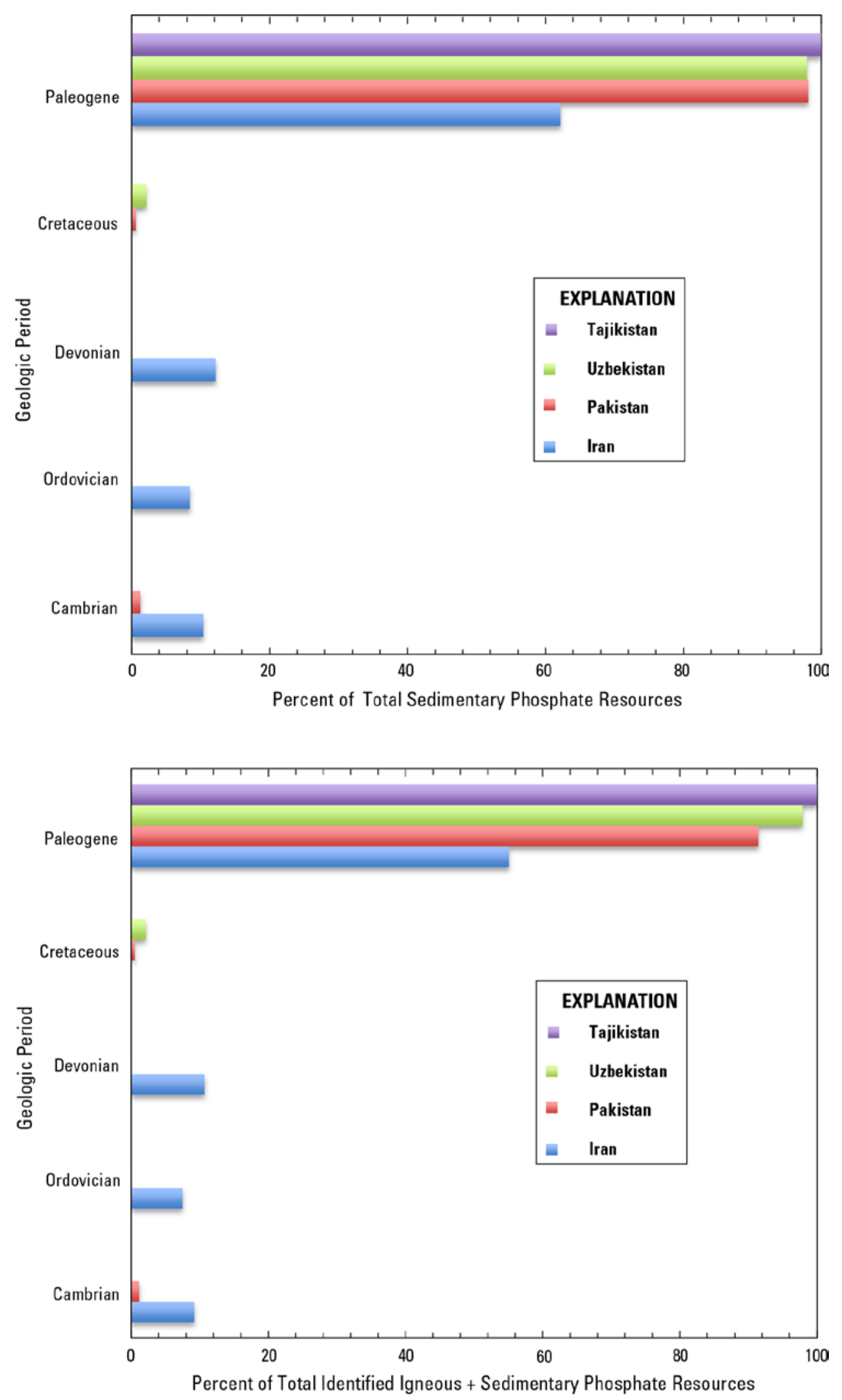

Figure 2. A) Percent of total known sedimentary phosphate resources by country and geologic age; $B$ ) Percent of total known igneous and sedimentary phosphate resources by country and geologic age. 


\section{Neoproterozoic-Cambrian Sedimentary Phosphate in Iran}

The Ediacaran-lower Cambrian phosphorite resources of Iran consist of large low-grade phosphorite with high levels of impurities (Ghorbani, 2013). The distribution of Cambrian sedimentary phosphate deposits and occurrences is shown in figure 4. These sediments are assigned to the Soltanieh Formation of the Alborz (Elburz) Mountains (fig. 3) and central Iran. The Soltanieh Formation crops out over a distance of almost $500 \mathrm{~km}$ across this area.

The Soltanieh Formation is Neoproterozoic (Ediacaran?) to lower Cambrian in age (Hamdi and others, 1989; Ghorbani, 2013) The Soltanieh can be divided into five members (fig. 5) - the Lower Dolomite, Lower Shale, Middle Dolomite, Upper Shale, and Upper Dolomite Members (Hamdi and others, 1989; Ghorbani, 2013). The Lower Dolomite and Lower Shale Members are Ediacaran in age and the upper three members are considered to be lower Cambrian (Jafari and others, 2007). Salehi (1989) thought that the phosphate in this formation was deposited in a largely shallow marine setting and that the dominant sedimentary process was chemical.

The Lower Dolomite Member is a well-bedded unit predominantly composed of recrystallized dolomite and limestone, cherty dolomite, and occasional thin shale or sandstone layers. The Lower Dolomite can be as much as 120-125 m thick, although commonly much thinner (Salehi, 1989). In the Valiabad area, this unit contains thin phosphatic beds (Hamdi and others, 1989; Ghorbani, 2013). In some areas, the Lower Dolomite is very thin or missing.

Just above the Lower Dolomite and possibly intergraded, the Lower Shale Member consists of dark gray to black shale with some limestone interbeds and, in places, phosphatic pellets (Jafari and others, 2007). The Lower Shale is reported to range from 130 to $240 \mathrm{~m}$ thick by Hamdi and others (1989), and is reported to be $151.7 \mathrm{~m}$ thick in the Takab area in northwest Iran by Jafari and others (2007).

The Middle Dolomite Member is composed of well-bedded dolomite and limestone with some shale or cherty layers. In places, the dolomite is reported to be stromatolitic and at least one phosphatic layer is found near or at the base of this unit. The Middle Dolomite Member commonly has a total thickness that ranges from about $50 \mathrm{~m}$ to more than $180 \mathrm{~m}$ (Hamdi and others, 1989; Jafari and others, 2007).

This Middle Dolomite is overlain by the Upper Shale Member which is less than $100 \mathrm{~m}$ to more than $150 \mathrm{~m}$ thick and coarser-grained than the Lower Shale (Hamdi and others, 1989). The base of the Upper Shale is largely composed of calcareous or silty shale and some phosphatic limestone. The main phosphate horizons occur near the base of the member.

The top of the Soltanieh Formation is composed of the Upper Dolomite Member, which is commonly the thickest member. It is more than $700 \mathrm{~m}$ thick in the Soltanieh area, but less than half that thickness in other areas (Hamdi and others, 1989). The dolomites of this member may be stromatolitic or cherty (Jafari and others, 2007).

Salehi (1989) reported the total phosphate resources of the Iranian Soltanieh Formation at 30 million metric tons containing 12 percent P2O5. More recent estimates (table 1) show a resource base roughly three times that tonnage, but averaging between 8 and 10 percent P2O5 overall. The more significant deposits include Dalir, Firuzabad, Valiabad, and Zanjan (Ghorbani, 2013). 


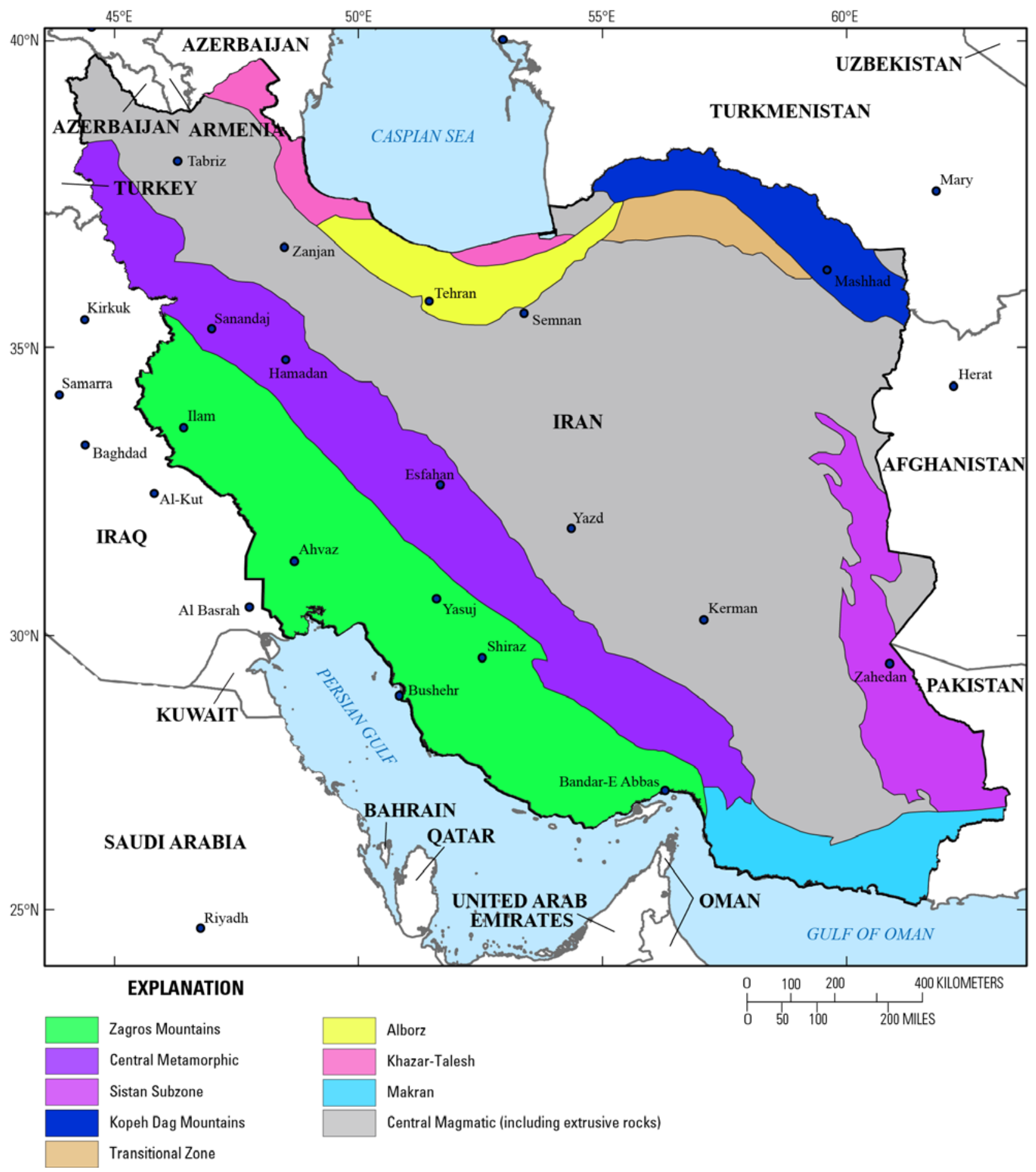

Figure 3. Map of the simplified structural zones of Iran. 


\section{Cambrian Sedimentary Phosphate in Pakistan}

In 1967, rock containing 30.6 percent P2O5 was identified by a graduate student near the town of Abbottabad in the Hazara District of the Northwest Frontier Province of Pakistan (fig. 6). The area of Cambrian sedimentary phosphate rock subsequently defined is commonly referred to as the Hazara or the Abbottabad Phosphate District and is the only area mined for phosphate in Pakistan (fig. 7). These phosphate deposits can be sporadically traced for more than $20 \mathrm{~km}$ and are believed to extend to the northwest and also to the southwest and west towards Afghanistan (Qureshi and others, 2001). Continuing investigations since 1971 have identified new areas of mineralization. However, there has only been a limited amount of detailed exploration work outside of the Hazara District.

\section{Hazara District}

The phosphorites of the Hazara District have varied compositions and appearances, although they are commonly dark-colored, granular or pelletal, compact, and hard (Ishaque and Ahmad, 1987; Hasan, 1989). The phosphorite horizons are rarely as much as 2 to $3 \mathrm{~m}$ thick and 140 specimens contained from 12 to 40 percent $\mathrm{P}_{2} \mathrm{O}_{5}$ (Ali, 1974). The phosphate pellets are commonly formed of collophane or francolite and gangue minerals include chert, dolomite, calcite, limonite, hematite, and quartz.

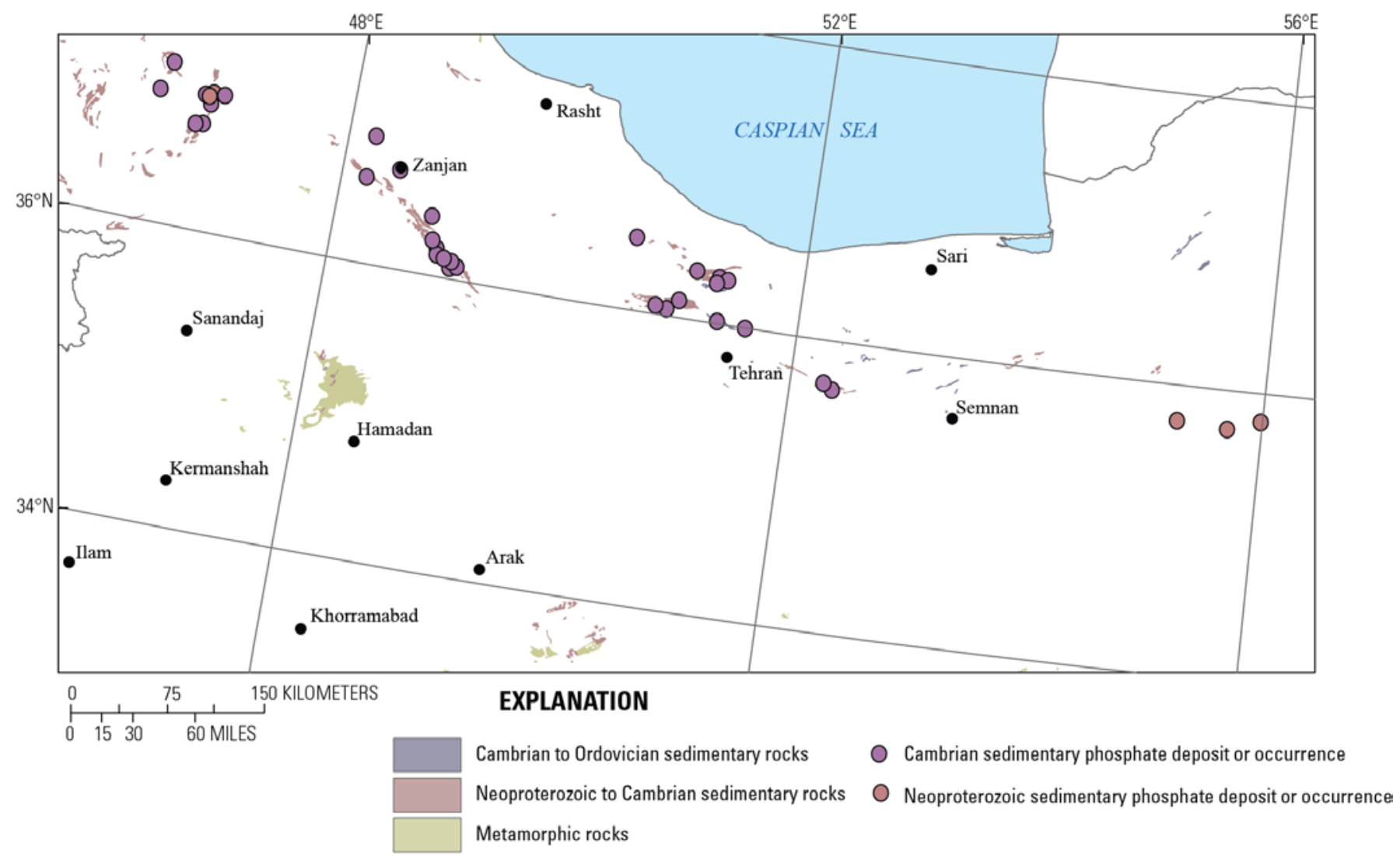

Figure 4. Distribution map of Cambrian sedimentary phosphate deposits and occurrences relative to outcrops of Cambrian sediments in northern Iran. 


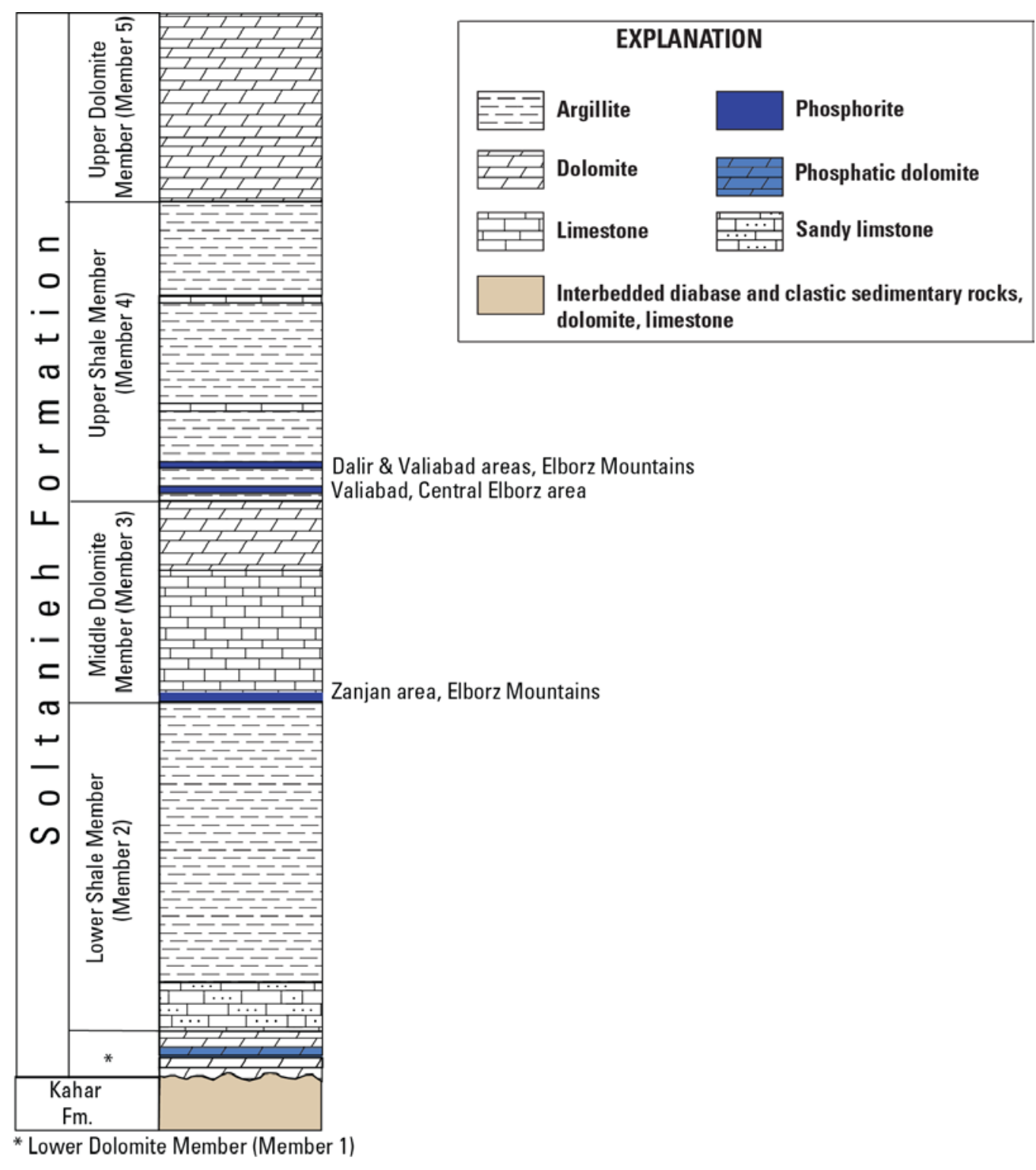

Figure 5. Generalized stratigraphic section of the Soltanieh Formation after Hamdi and others (1989) and Ghorbani (2013) showing where phosphorite has been reported. 


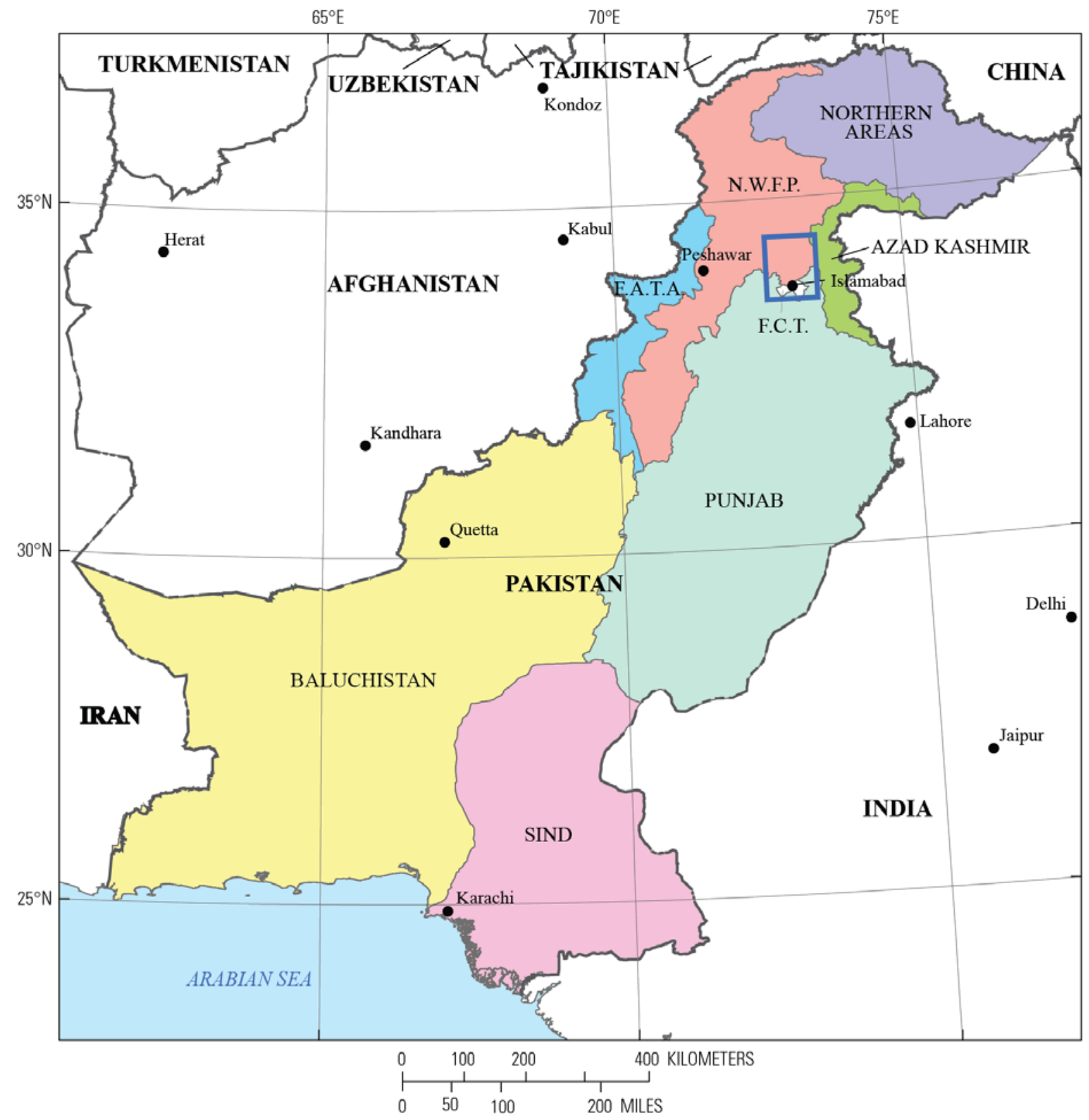

Figure 6. Map of the provinces of Pakistan. F.A.T.A., Federally Administered Tribal Areas; F.C.T., Federal Capital Territory; N.W.F.P, North-West Frontier Province.

Within the Hazara Phosphate District, sediments range in age from Precambrian to Quaternary. The Precambrian and some of the early to middle Paleozoic sediments are clastic; this was followed by long periods of carbonate deposition from the Cambrian to the Eocene (Hasan, 1989). The Himalayan orogeny (Paleogene to early Neogene (?)) is reflected in the deformation of all rocks in the region.

According to Bilqees (1995), the phosphates originally formed as orthochemical phosphate or phosphate mud. During subsequent reworking of the mud, pellets and pseudo-oolites were formed. Bilqees also notes that the cyclic repetition of strata at Kakul and other localities suggest that marine 
transgression and regression controlled the deposition of the Hazara phosphates within a broad shelf setting.

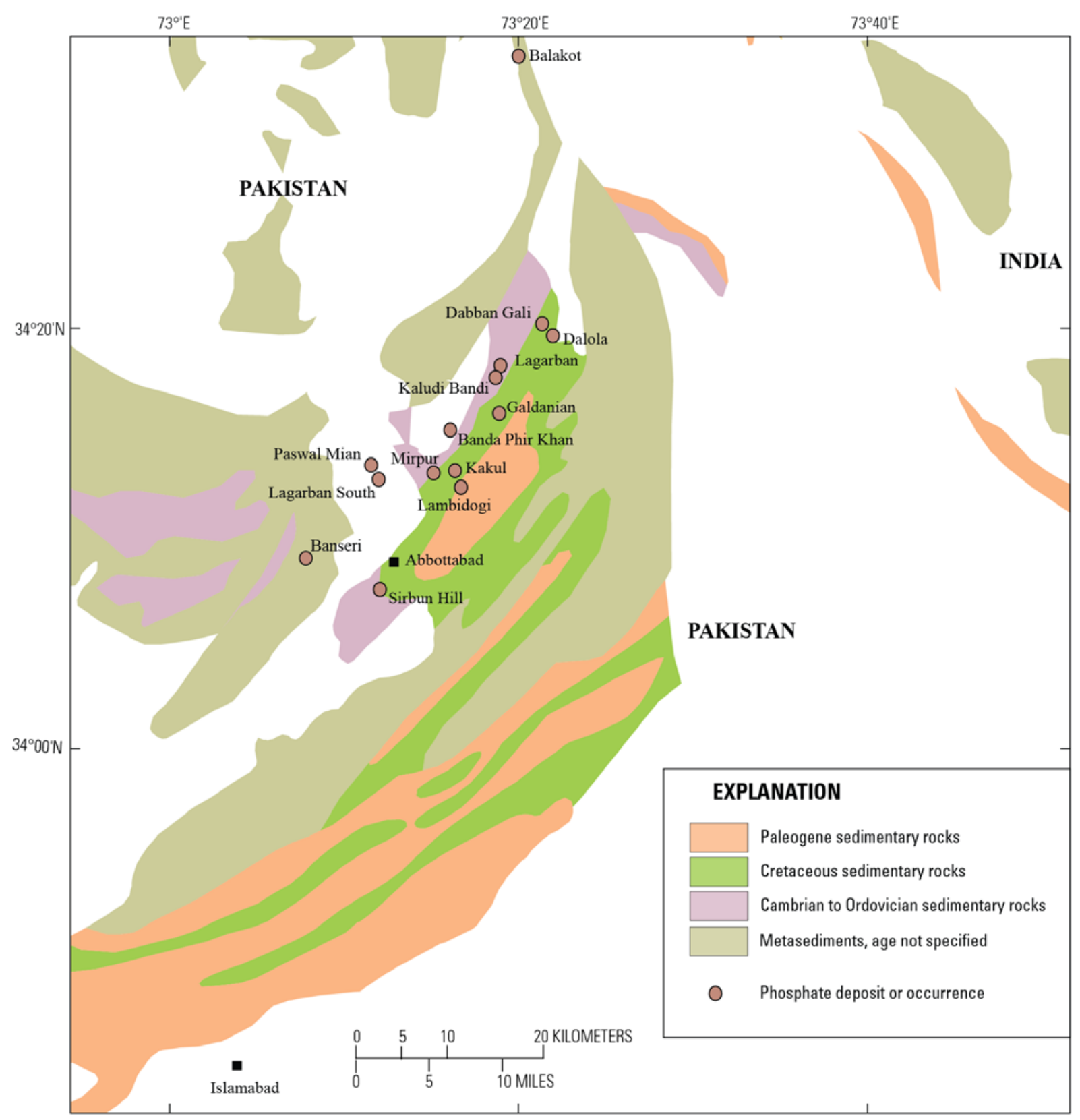

Figure 7. Geologic map of the phosphate district near Abbottabad, Hazara District, Northwest Frontier Province, Pakistan. The location of this figure is shown on figure 6.

\section{Abbottabad Formation and Hazira Member of the Tarnawai Formation}

The Hazara phosphates are found in Cambrian sediments of two horizons or formations. The lower horizon (Abbottabad Formation) contains most of the phosphate deposits. This horizon is exposed at Kakul, Lagarban, Lambidogi, Tarnawai, Sirban, and Sobrah Gali. In the Abbottabad 
Formation, the phosphate is cherty and forms beds, stringers, and lenticules. It is hosted by cherty dolomite (Hasan, 1989; Bilqees, 1995). The dolomite member of the Abbottabad Formation is as much as $600 \mathrm{~m}$ or more thick (Ali, 1974).

The upper horizon (Hazira and Galdanian Members of the Tarnawai Formation) is exposed at Dalola and at Sirban. The phosphate at these locations is associated with hematitic and (or) calcareous siltstone (Hasan, 1989; Bilqees, 1995).

At Kakul, there are two phosphate horizons. Both horizons are of variable thickness, but locally can be as much as $5 \mathrm{~m}$ thick (Qureshi and others, 2001). The upper horizon is found at the contact of the Hazira Member of the Tarnawai Formation and Abbottabad Formations and is hosted by cherty dolomite. The lower phosphate horizon is found about $32 \mathrm{~m}$ from the top of the Abbottabad Formation and is hosted by dolomitic limestone (Qureshi and others, 2001).

\section{Ordovician Sedimentary Phosphate}

Of the 20 reported occurrences of Ordovician-age marine sedimentary phosphorite in the countries bordering Afghanistan, all are located in Iran (fig. 8). The phosphorite occurs in largely clastic sedimentary rocks including shale, sandstone, and quartzite. Reports of limestone and dolomite in the phosphorite-hosting sedimentary sequences are rare.

\section{Ordovician Phosphorite in Iran}

Phosphate has been identified in Ordovician sedimentary rocks in the South Khorasan and Kerman Provinces of Iran, and in the Zagros Mountains of southwest Iran (fig. 8). The most important occurrences are found in the shale-sandstone sequences of the Shirgesht Formation (Yazd, Kerman, and Khorasan Provinces) with deposits in other parts of Iran hosted by the Milla Formation (Ghorbani, 2013). Phosphorite horizons in the Milla Formation are commonly 5 to $70 \mathrm{~cm}$ thick, although in one location the phosphorite is reported to be as much as $8 \mathrm{~m}$ thick; grades range from 0.1 to 22.5 percent $\mathrm{P}_{2} \mathrm{O}_{5}$ (Iran Geological Survey, 2013a). Little quantitative information was found for occurrences in the Shirgesht Formation, but reported grades for three sites ranged from 0.04-11.1 percent $\mathrm{P}_{2} \mathrm{O}_{5}$ with reported thickness' of 20 to more than $300 \mathrm{~cm}$ (Iran Geological Survey, 2013a). The larger occurrences include Rahdar, Dahoieh-Zarand, and Kalmard. Small occurrences are also found in the Zagros Mountains associated with sandstone and limey sandstone. The phosphorite is described as being laminated for several of the Ordovician occurrences. Overall, Ghorbani (2013) reports that Ordovician phosphorite has no economic value.

\section{Devonian Sedimentary Phosphate}

All of the 46 reported deposits and occurrences of Upper Devonian-age sedimentary marine phosphorite in the study area are located in Iran (fig. 8). The sediments of this age were dominated by marine transgression, particularly in the Alborz region (Ghorbani, 2013). The phosphate-bearing Fammenian sediments represent a marine sequence characteristic of platform sedimentation; the sequence contains large amounts of clastic continental detrital material (Salehi, 1989). 


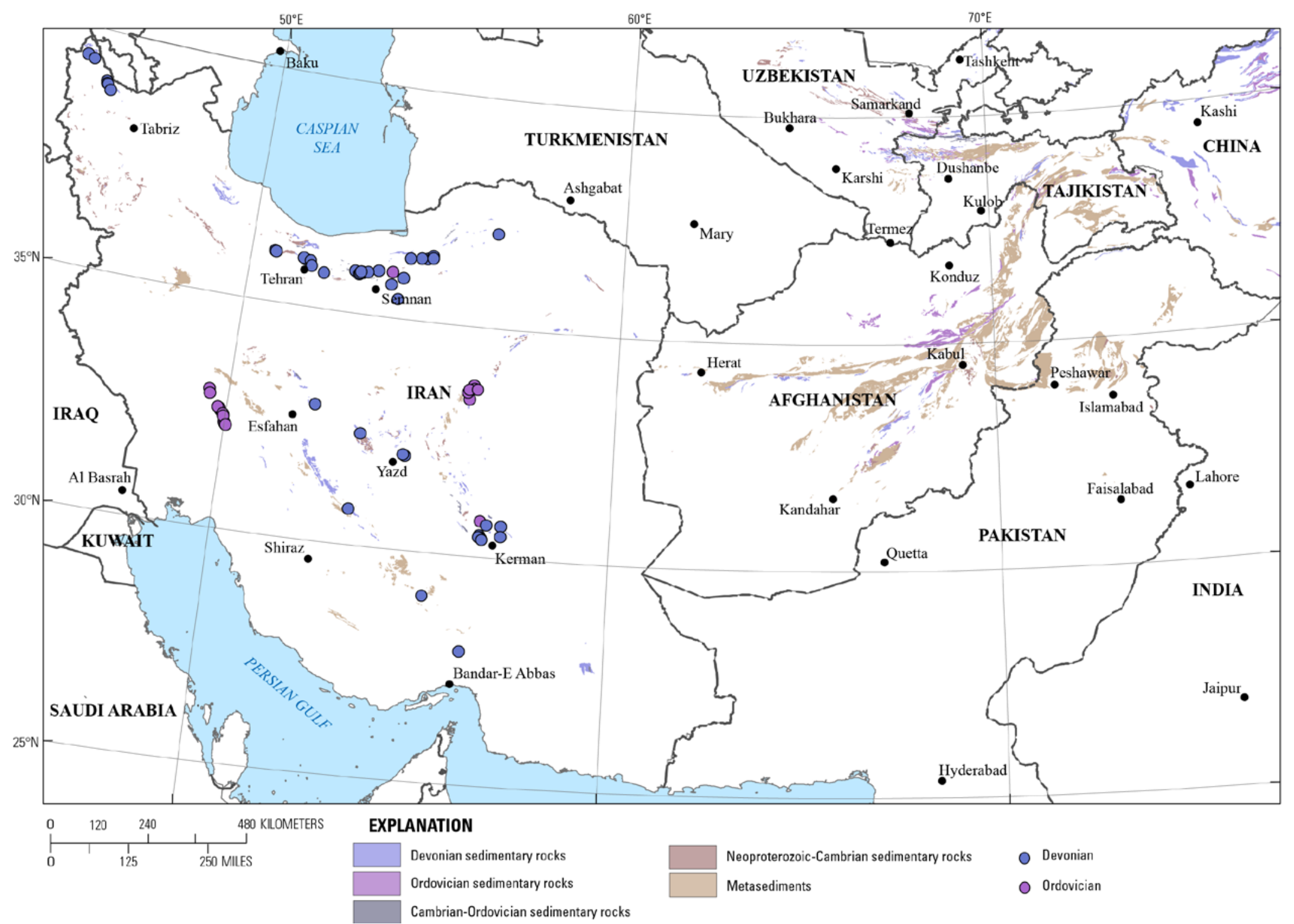

Figure 8. Distribution of Ordovician and Devonian sedimentary phosphate in the study area showing outcrops of Ordovician and Devonian sediments. 


\section{Devonian Sedimentary Phosphorite in Iran}

The Devonian phosphate deposits and occurrence of Iran are largely found in the Jeirud Formation in the area of the Alborz Mountains, but extend into central Iran and north into Azerbaijan (Notholt and others, 1989b). Other host formations for phosphate-bearing sediments of this age include the Shistu, Bahram, and Faraghun Formations. The identified resources and reserves of Devonian phosphate rock in Iran are all hosted by the Jeirud Formation and include deposits at Firuzkuh, Gaduk, Jeirud, and Paghaleh.

The Upper Devonian to lower Carboniferous Jeirud Formation rests unconformably on limestone of the Cambrian Mila Formation (Dastanpour, 1996), and is overlain by fossiliferous limestone and marly shale of the Mobarak Formation. Several beds of phosphorite occur in the lowermost part of the formation. The host sediments are dominated by sandstone and glauconitic sandstone, but may include shale, sandy limestone, and fossiliferous limestone. Widespread black pelletal lenticular phosphorite beds with some reworked clasts and phosphatized fossils were identified in the lower part of the formation in 1965 in the Lalun Valley (Salehi, 1989). Individual phosphatebearing beds are 1-2 m thick and separated by sandstone or shale, with the overall phosphate-enriched zone as much as $70 \mathrm{~m}$ thick (Ghorbani, 2013). The phosphate is present in the form of cryptocrystalline francolite (Ghorbani, 2013). In places, surficial weathering has led to the development of wavellite.

The Upper Devonian Bahram Formation consists of limestone with dolomite, sandstone, and shale (Dastanpour, 1996; Ghorbani and others, 2014). Bioclastic grainstones locally contain phosphatic fossils and (or) cement; the unit also contains thin-bedded phosphate-bearing limestones that formed in a shallow open marine environment and are intercalated with shale (Ghorbani and others, 2014). The Iran Geological Survey (2013a) reports 2 to 9.4 percent $\mathrm{P}_{2} \mathrm{O}_{5}$ in Bahram Formation phosphate rock 20$145 \mathrm{~cm}$ thick at Kuh-e-Shurab.

The Faraghun Formation is composed of sandstone with intercalations of shale and limestone. It has a disconformable contact with the underlying Silurian rocks. The formation ranges from Lower Devonian to Cisuralian (early Permian) in age (Ghavidel-Syooki, 1988). There is a break or hiatus in the Faraghun Formation that roughly corresponds to the Hercynian Orogeny; Fammenian through Carboniferous (and possibly earliest Permian) age rocks are missing. Phosphatic rocks occur in the Upper Devonian section of the formation. In places, the Upper Devonian part of the formation is reported to be 60-75 m thick below 25-40 m of Cisuralian sediments (Ghavidel-Syooki, 1988). At Faraghun, as much as 25 percent $\mathrm{P}_{2} \mathrm{O}_{5}$ is reported in phosphate rock 400-1200 cm thick (Iran Geological Survey, 2013a).

Most of the Shistu Formation is Upper Devonian in age, although the upper member of the formation has been included in the base of the Carboniferous (Vachard, 1996; Dastanpour, 1996). The Devonian part of the Shistu Formation, where the phosphate is reported to occur, is composed of limestone, shale, sandstone, dolomite, and oolitic ironstone (Vachard, 1996; Iran Geological Survey, 2013a). Dastanpour (1996) reports that the Shistu Formation is 250-400 m thick. At Mazraeh-e-No, a 40-cm thick unit is reported to contain 6 percent $\mathrm{P}_{2} \mathrm{O}_{5}$ (Iran Geological Survey, 2013a).

\section{Permian Sedimentary Phosphate}

Only two occurrences of Permian-age marine phosphorite were identified in the study area; one in Iran and one in Afghanistan. In earlier literature, such as the publication by Ali (1974) on phosphate deposits in Pakistan, several deposits are considered to be Permian in age, but later work has 
shown most of these deposits and occurrences to be other ages. Neither of the two known Permian phosphorites has reported resources or reserves.

\section{Permian Sedimentary Phosphate in Afghanistan}

There is one reported occurrence of Permian sedimentary phosphate in Afghanistan in the publication by Abdullah and others (1980). Although discussed by Abdullah and others in their text, the occurrence is not included in their list of deposits and occurrences. The Permian phosphate rock is reported to occur in the Darrah-i-Begaw Valley of northern Badakshan. The phosphate occurs in polymictic sandstone near the top of a fossiliferous sequence of Permian sediments that form a wedgeshaped fault block as much as $50 \mathrm{~km}$ long by 2 to $7 \mathrm{~km}$ wide (Abdullah and others, 1980; Afghanistan Ministry of Mines and Petroleum, 2014).

\section{Permian Sedimentary Phosphate in Iran}

There is one reported occurrence of Permian-age sedimentary phosphate in Iran. The Iran Geological Survey (2013a) reports that the Abkhory occurrence in Semnan Province consists of pelletal phosphate in quartzite of the Permian Dorud Formation. The phosphate is found in a horizon reported to be $1000 \mathrm{~cm}$ thick and containing 0.27 to 3.93 percent $\mathrm{P}_{2} \mathrm{O}_{5}$; this deposit is not considered to be of sufficient size and grade to be economically exploited.

\section{Triassic-Jurassic Sedimentary Phosphate}

A handful of sedimentary phosphate occurrences in Iran and Pakistan are attributed with Triassic or Jurassic ages. No identified reserves or resources have been found in sediments or metasediments of these ages.

\section{Triassic-Jurassic Sedimentary Phosphate in Iran}

Two phosphate rock occurrences are reported in Triassic-Jurassic sediments/metasediments by Ghorbani (2013). The Taleghan occurrence is described as a stratiform occurrence in Jurassic sedimentary rocks. The Hoseyn Abad occurrence is found in Triassic-Jurassic phyllite and schist. In addition to being metamorphosed, the occurrence at Hoseyn Abad shows signs of hydrothermal activity (Ghorbani, 2013).

\section{Triassic-Jurassic Sedimentary Phosphate in Pakistan}

Ali (1974) reports that an exposed horizon of the Shirinab Formation in the Zhob District of Baluchistan contains as much as 8 percent $\mathrm{P}_{2} \mathrm{O}_{5}$. The unit is composed of Upper Triassic thin-bedded and dark flaggy siltstone with thin bands of chert. No site name or more detailed location is provided with this information. He also reports a phosphate zone in a Jurassic horizon of the Chichali Formation in the Peshawar District, but again no additional information is provided.

\section{Cretaceous Sedimentary Phosphate}

There are 30 reported phosphate rock occurrences of Cretaceous age in Afghanistan and adjacent countries. Twenty-six of these occurrences are in Iran, six are in Pakistan, three in Uzbekistan, and one in Afghanistan. There are no identified phosphate resources or reserves of Cretaceous age in the study area. 


\section{Cretaceous Sedimentary Phosphorite in Afghanistan}

During the Upper Cretaceous and Paleogene, there was a shallow marine shelf adjacent to the continental margin at low latitudes; a favorable environment for phosphate deposition (Afghanistan Ministry of Mines and Petroleum, 2014). A single occurrence of Upper Cretaceous-age phosphate rock is reported at Kotal-i-Sabzak in the Herat Province (Abdullah and others, 1980; Economic and Social Commission for Asia and the Pacific, 1995). Gray to black phosphatic nodules $0.5-6 \mathrm{~cm}$ in size occur in claystone $0.3-1.0 \mathrm{~m}$ thick at the base of the Upper Cretaceous sediments. In addition to the nodules, phosphatized fossils are found throughout the unit. Samples of the phosphatic material are reported to contain 6.2-0.7 percent $\mathrm{P}_{2} \mathrm{O}_{5}$.

\section{Cretaceous Sedimentary Phosphorite in Iran}

The Upper Cretaceous phosphate-bearing Gurpi Formation is largely composed of dark gray marl, shale, and limestone. It has a disconformable contact with the overlying Paleogene phosphatebearing Pabdeh Formation which typically cannot be recognized in the field, but is apparent on examination of microfossils (Bahrami, 2009; Soleimani, 2009). This disconformity results from the extreme folding and metamorphism that occurred in central Iran at the end of the Maastrichtian (Ghorbani, 2013).

In the Zagros zone, phosphate occurrences are frequently found in Cretaceous beds associated with Paleogene phosphate mineralization. Such occurrences are not well described compared to the more dominant Paleogene mineralization, but are known at Behbahan, Lar, Sheikh Habil, Kuh-eKumeh, Kuh-e-Safid, and Kuh-e-Rish (Ghorbani, 2013).

\section{Cretaceous Sedimentary Phosphorite in Pakistan}

Most of the Cretaceous-age phosphate rock in Pakistan is reported to occur in the upper part of the Upper Jurassic to Lower Cretaceous Chichali Formation (fig. 9). The Chichali Formation consists of glauconitic quartzose sandstone and sandy glauconitic shale with a total thickness of as much as 60 m (Hallam and Maynard, 1987; Qureshi and others, 2007). In the Salt Range, the Upper Member is composed of layered fine glauconitic sand that contains phosphate-cemented spherical nodules that are approximately $5 \mathrm{~cm}$ in size (Hallam and Maynard, 1987). Phosphate nodules about $2 \mathrm{~cm}$ in diameter are also found scattered in the Lower Member of the Chichali Formation. In the Peshawar District, Ali (1974) reports black phosphate nodules as much as $10 \mathrm{~cm}$ in diameter that are more numerous in the lower part of the glauconitic beds, and phosphate grades of 5 to 15 percent $\mathrm{P}_{2} \mathrm{O}_{5}$.

The Upper Cretaceous Mughal Kot Formation is reported to contain phosphate nodules at Karim Kach Khwar in the Zhob District of Baluchistan Province. The formation is composed of shale, marl, sandstone, and limestone. The nodules are reported to contain about 5 percent $\mathrm{P}_{2} \mathrm{O}_{5}$ (Ali, 1974).

Upper Cretaceous-age phosphate has also been reported to occur in the Kawagarh Formation in the Campbellpur District of the Northwest Frontier Province (Ali, 1974). The host limestone contains a phosphatic bed that is about $20 \mathrm{~cm}$ thick and dark in color. The formation is highly folded and faulted and the phosphate bed notably changes grade and appearance laterally.

\section{Cretaceous Sedimentary Phosphorite in Uzbekistan}

Two deposits and occurrences of phosphate in Upper Cretaceous (Campanian) sedimentary rocks were identified in Uzbekistan, Khodzheilin and Ketmenchy. Younger Paleocene phosphate rock is also present (Il'yashenko, 1967). At both Ketmenchy and Khodzheilin, a layer of Campanian clay as much as $0.2 \mathrm{~m}$ thick contains nodular phosphate of unspecified size. 


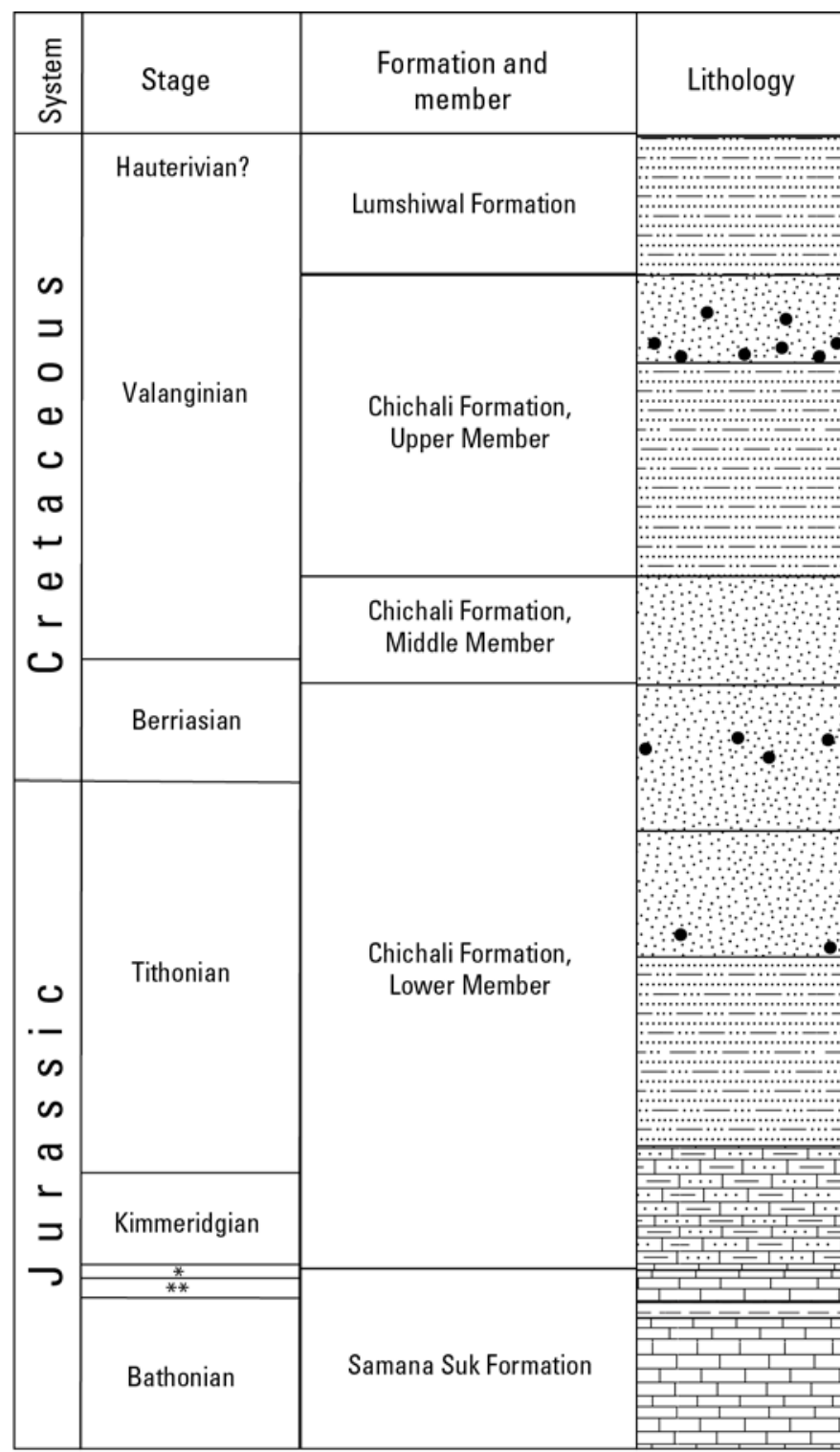

\section{EXPLANATION}

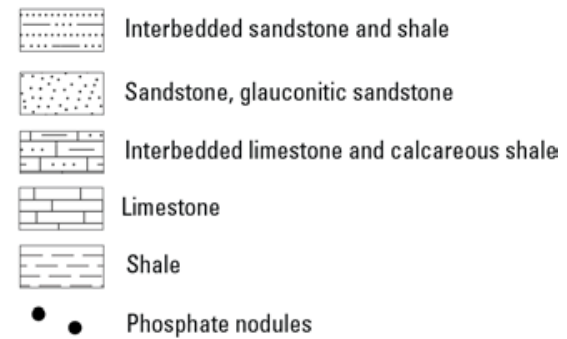

- - Phosphate nodules

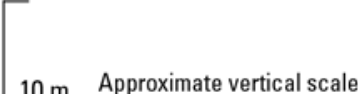

${ }^{*}$ Oxfordian, ${ }^{* *}$ Callovian

Figure 9. Stratigraphic section of the Chichali Formation in the Salt Range (modified from Hallam and Maynard, 1987).

\section{Paleogene Sedimentary Phosphate}

There are more than 150 deposits and occurrences of Paleogene-age marine phosphorite in the countries bordering Afghanistan (figs. 1, 2). More than 100 of these sites are located in Iran and Uzbekistan, with those in Uzbekistan located closest to the Afghanistan border. Marine phosphorite of Early Cambrian, Late Cretaceous, and Paleogene age in Pakistan occurs within about $100 \mathrm{~km}$ of the border with Afghanistan. The grades and thicknesses of the Paleogene deposits and occurrences vary widely with $\mathrm{P}_{2} \mathrm{O}_{5}$ values ranging from less than 5 percent to more than 25 percent (table 2). Paleogene sedimentary phosphorite was deposited on the northern Tethys shelf (Ilyin and Boiko, 1989) and 
adjacent areas (fig. 10). During the early Paleocene, phosphatic pebble beds were deposited in the vicinity of the Aral Sea. At the same time phosphate nodules formed in carbonate sediments west of the Aral Sea (fig. 11). The phosphate nodules of this age appear to have been reworked and resedimented (Yanshin, 1982). By the late Paleocene, nodular phosphate was also accumulating in the western Kyzyl Kum area of Uzbekistan (fig. 11).

At the start of the Eocene, marine transgression shifted the site of phosphate accumulation to the east, with deposition in the central Kyzyl Kum area and in the Tajik depression (Yanshin, 1982). During the early Eocene, a deep-water environment was present in the area now occupied by the lower reaches of the Amu Darya River (fig. 1), and this prevented phosphate deposition in this area (Ilyin and Boiko, 1989; Yanshin, 1982). By the middle Eocene, granular phosphate, consisting largely of skeletal remains, was being deposited over much modern Uzbekistan and neighboring regions. During this period, the phosphate deposition was most efficient in the central Kyzyl Kum area where a broad relatively shallow shelf was present (Ilyin and Boiko, 1989). Granular phosphate was also deposited in the Surkhdariya, Fergana, and Pendzhikent depressions. South of the Aral Sea area (fig. 11), nodular and pebble phosphate predominated.

Much of the Eocene phosphate deposition consisted of phosphatized skeletal and other organic remains, including nannoplankton, foraminifera, and coprolites (Ilyin and Boiko, 1989). The abundance of nannoplankton shows replacement of calcareous material by phosphate took place in areas well removed from a detrital source and that deposition occurred in marine water of normal salinity at 18 to $20^{\circ} \mathrm{C}$ (Ilyin and Boiko, 1989). It is likely that upwelling induced high organic productivity during the Eocene, and that resulting organic decay created a higher concentration of dissolved phosphorus in bottom and interstitial waters contributing to the formation of nannoplankton ooze (Ilyin and Boiko, 1989). 


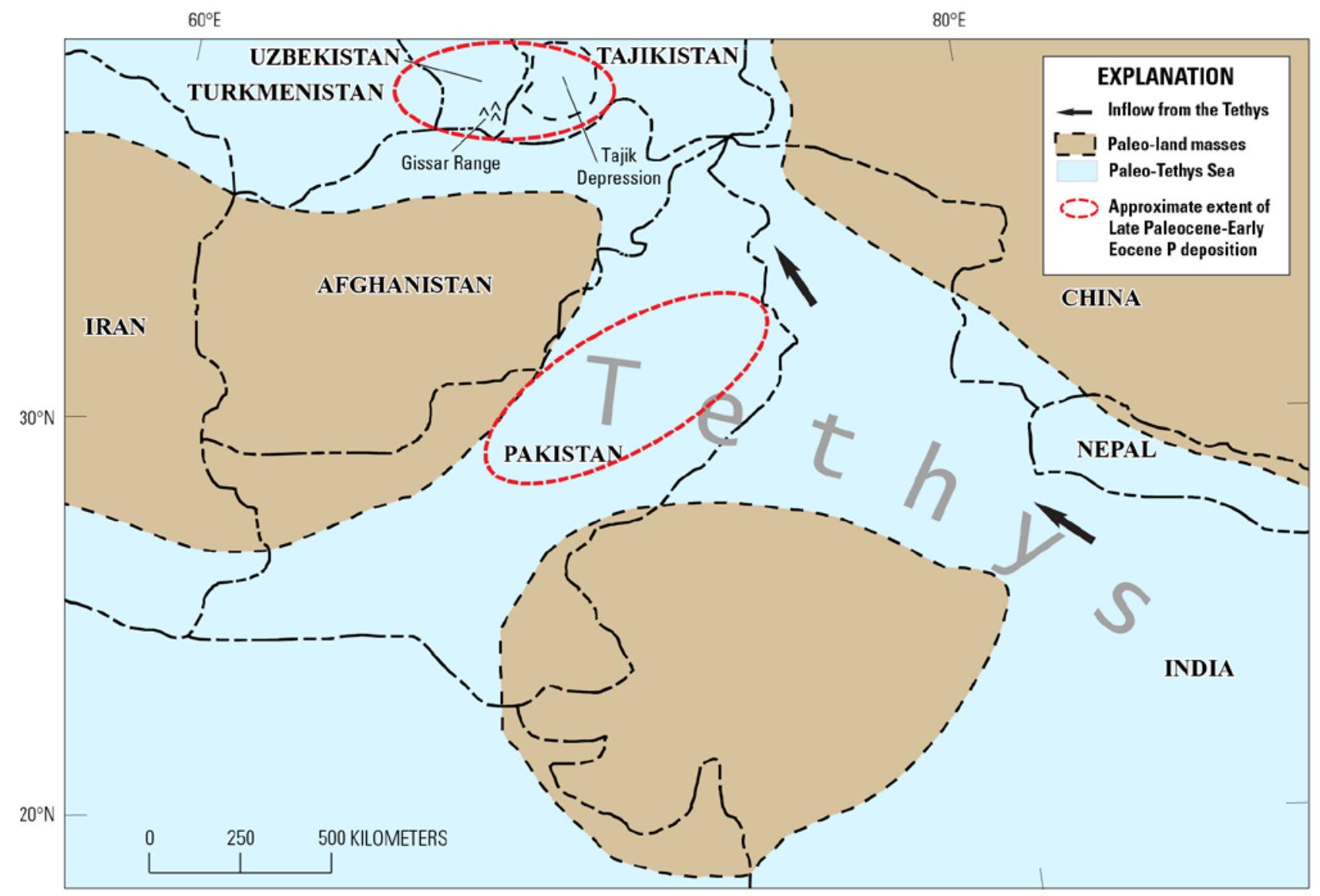

Figure 10. Paleogeographical scheme after Akhmetiev and others (2012) showing approximate areas of Late Paleocene to Early Eocene phosphate deposition within paleo-Tethys Sea basin areas of present day Uzbekistan and Pakistan. 
During the Paleogene, phosphate formation was most intense in the Dosmangy, Babatag-South Gissar, Shurasan, and Pendzhikent areas of Central Asia (fig. 11). Il'yashenko (1967) reported that phosphate accumulation was less intense in the Kyzyl Kum, Kara Kalpak, Fergana Basin, southeast Gissar Range, and southwestern Tajik Basin (fig. 11) at this time. It should be noted that several regionally significant discoveries of phosphate have been made in the Kyzyl Kum area subsequent to his report.

Paleogene phosphate in Iran formed in a long, narrow east-west trending seaway with a strong westerly ocean current that generated dynamic upwelling and subsequent phosphate deposition. Within the seaway, structural elements also played important roles in phosphate deposition and location (Notholt and others, 1989b).

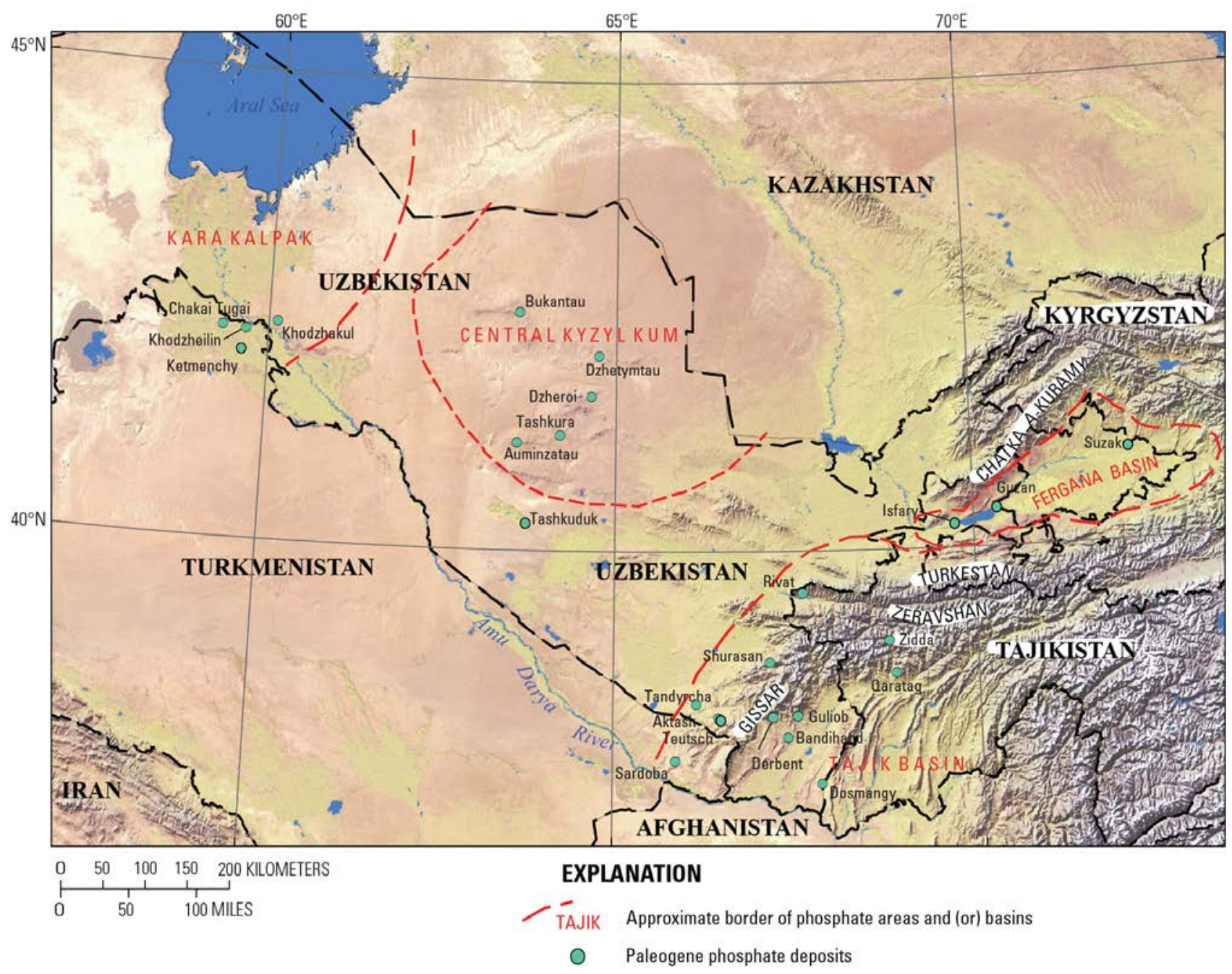

Figure 11. Index map showing geographic locations and phosphate deposits and occurrences mentioned in the text. 
Table 2. Thickness and $\mathrm{P}_{2} \mathrm{O}_{5}$ content of some Paleogene phosphorite occurrences in Central Asia. $\mathrm{P}_{2} \mathrm{O} 5$ contents are assumed to be in weight percent, although this was not specified in the sources.

[m, meters; - , not reported]

\begin{tabular}{|c|c|c|c|c|c|c|}
\hline \multirow[b]{2}{*}{ Site } & \multicolumn{3}{|c|}{ No. of } & \multicolumn{2}{|c|}{$\mathrm{P}_{2} \mathrm{O}_{5}$ content (in percent) } & \multirow[b]{2}{*}{ Source } \\
\hline & $\begin{array}{l}\text { No. of } \\
\text { samples }\end{array}$ & $\begin{array}{l}\text { phosphorite } \\
\text { horizons }\end{array}$ & $\begin{array}{l}\text { Average } \\
\text { thickness } \\
(\mathrm{m})\end{array}$ & Range & Average & \\
\hline
\end{tabular}

\section{KARA KALPAK AREA (UZBEKISTAN)}

$\begin{array}{llll}\text { Chakai Tugai } & 26 & 1 & 0.30 \\ \text { Ketmenchy } & 1 & 1 & 0.44 \\ \text { Khodzhakul } & 89 & 1 & 0.30 \\ & & 2 & 0.30 \\ \text { Khodzheilin } & 2 & 1 & 0.2 \\ & 22 & 2 & 0.25\end{array}$

$\begin{array}{lll}0.30 & 2.23-8.80 & 4.86 \\ 0.44 & 4.8 & - \\ 0.30 & 0.80-11.61 & 5.60 \\ 0.30 & 12.0-15.0 & 12.6 \\ 0.2 & \text { Up to } 7.0 & - \\ 0.25 & 1.65-10.06 & 8.5\end{array}$

Il'yashenko (1967)

Il'yashenko (1967)

Il'yashenko (1967)

Il'yashenko (1967)

Il'yashenko (1967)

Il'yashenko (1967)

KYZYL KUM AREA

$\begin{array}{lll}\text { Auminzatau } & 20 & 1 \\ \text { Balakarak } & 10 & 1 \\ \text { Bukantau } & 25 & 1 \\ \text { Dzheroi } & 1 & \\ \text { Dzhetymtau } & 1 & \\ & 1 & \\ \text { Shurasany } & 1 & 1 \\ \text { Shirabad } & 1 & 1 \\ \text { Tashkuduk } & 8 & 1\end{array}$

$\begin{array}{lll}0.2 & 3.17-12.67 & 7.81 \\ 0.15 & 4.36-12.90 & 4.72 \\ 0.25 & 1.61-5.20 & 3.72 \\ - & 27.80 & - \\ - & 26.86 & - \\ & 20.90 & - \\ 0.9 & 8.43 & - \\ 1.0 & 4.29 & - \\ 0.20 & 5.14-9.78 & 8.40\end{array}$

Il'yashenko (1967)

Il'yashenko (1967)

Il'yashenko (1967)

Yanshin (1982)

Yanshin (1982)

Yanshin (1982)

Il'yashenko (1967)

Il'yashenko (1967)

Il'yashenko (1967)

TAJIK BASIN AREA

Dosmangy

$\begin{array}{lll}\text { Dosmangy } & 1 & 1 \\ & 1 & 2 \\ \text { Guliob } & 1 & 3 \\ & 1 & 4 \\ & 1 & 1 \\ & 3 & 2 \\ & 14 & 3 \\ & 3 & 4 \\ & 2 & 5 \\ & 4 & 6 \\ & 1 & 7 \\ & 3 & 8 \\ & 1 & 9 \\ & 1 & 1 \\ & 2 & 11 \\ & 1 & 12 \\ \text { Qaratag area } & 1 & 13 \\ \text { Rivat } & 1 & 14 \\ & 2 & 15 \\ & 1 & 16 \\ & 42 & 1 \\ & & 2\end{array}$

Teutsch

unknown

$\begin{array}{lll}1.75 & 4.26 & - \\ 0.20 & 12.42 & - \\ 1.75 & 8.13 & - \\ 0.35 & 20.4 & - \\ 0.3 & 4.56 & - \\ 1.03 & 4.27-12.90 & 7.18 \\ 1.5 & 4.38-6.44 & 5.49 \\ 0.65 & 5.03-7.62 & 6.35 \\ 1.0 & 7.43 & - \\ 1.0 & 7.43-10.77 & 8.92 \\ 0.4 & 5.51 & - \\ 0.82 & 6.08-21.66 & 13.39 \\ 0.5 & 5.79 & - \\ 0.5 & 7.10 & - \\ 0.26 & 7.50-21.87 & 14.68 \\ 0.55 & 10.25 & - \\ 0.75 & 6.09 & - \\ 0.75 & 5.38 & - \\ 0.5 & 8.28-22.30 & 11.8 \\ 0.35 & 4.19 & - \\ & 18.98 & \\ 0.4 & 12.79-16.71 & 15.12-15.96 \\ 0.61 & 2.14-9.82 & 4.23-4.3 \\ 0.56-2.27 & 3.04-9.38 & 4.7-5.24 \\ 0.98-4.38 & 1.02-14.84 & 5.05-5.88 \\ 0.2 & & \end{array}$

Il'yashenko (1967)

Il'yashenko (1967)

Il'yashenko (1967)

Il'yashenko (1967)

Il'yashenko (1967)

Il'yashenko (1967)

Il'yashenko (1967)

Il'yashenko (1967)

Il'yashenko (1967)

Il'yashenko (1967)

Il'yashenko (1967)

Il'yashenko (1967)

Il'yashenko (1967)

Il'yashenko (1967)

Il'yashenko (1967)

Il'yashenko (1967)

Il'yashenko (1967)

Il'yashenko (1967)

Il'yashenko (1967)

Il'yashenko (1967)

Yanshin (1982)

Il'yashenko (1967)

Il'yashenko (1967)

Il'yashenko (1967)

Il'yashenko (1967)

Il'yashenko (1967) 


\begin{tabular}{|c|c|c|c|c|c|c|}
\hline \multirow[b]{2}{*}{ Site } & \multirow[b]{2}{*}{$\begin{array}{l}\text { No. of } \\
\text { samples }\end{array}$} & \multirow{2}{*}{$\begin{array}{l}\text { No. of } \\
\text { phosphorite } \\
\text { horizons }\end{array}$} & \multirow[b]{2}{*}{$\begin{array}{l}\text { Average } \\
\text { thickness } \\
(\mathrm{m})\end{array}$} & \multicolumn{2}{|c|}{$\mathrm{P}_{2} \mathrm{O}_{5}$ content (in percent) } & \multirow[b]{2}{*}{ Source } \\
\hline & & & & Range & Average & \\
\hline \multirow{8}{*}{ Ziddin } & 114 & 2 & 0.65 & $2.99-18.59$ & 8.98 & Il'yashenko (1967) \\
\hline & & 3 & 0.77 & $1.50-10.08$ & 5.81 & Il'yashenko (1967) \\
\hline & & 4 & 0.55 & $1.74-11.30$ & 3.57 & Il'yashenko (1967) \\
\hline & & 5 & 0.68 & 6.84 & - & Il'yashenko (1967) \\
\hline & & 6 & 1.14 & $1.88-12.79$ & 8.48 & Il'yashenko (1967) \\
\hline & & 7 & 0.52 & $3.16-15.16$ & 10.22 & Il'yashenko (1967) \\
\hline & & 8 & 0.78 & $1.31-18.15$ & 6.95 & Il'yashenko (1967) \\
\hline & & 9 & 0.42 & $1.82-10.43$ & 6.25 & Il'yashenko (1967) \\
\hline \multicolumn{7}{|c|}{ FERGANA BASIN (UZBEKISTAN) } \\
\hline Isfary & 7 & 1 & 0.46 & $4.91-11.95$ & 7.80 & Il'yashenko (1967) \\
\hline Guzan & 4 & 1 & 0.06 & $9.59-15.76$ & 13.04 & Il'yashenko (1967) \\
\hline Suzak & 1 & 1 & 0.4 & 5.00 & - & Il'yashenko (1967) \\
\hline
\end{tabular}

\section{Paleogene Sedimentary Phosphate in Afghanistan}

Although no Paleogene sedimentary phosphate deposits or occurrences have been located in Afghanistan, phosphatic rock has been noted in Paleogene sediments found in drill holes in the Afghan-Tajik Basin area (Klett and others, 2006). Phosphatic mineralization is reported to occur in the lower Eocene Suzak Suite, which is found in the Amu Darya and Afghan-Tajik Basin sediments and in the overlying middle Eocene Alay Suite.

According to Klett and others (2006), the Suzak Suite is widely distributed in Central Asia (fig. 12) and ranges from 10 to $180 \mathrm{~m}$ thick. It includes the Givar horizon, which in turn is divided into the lower Kaptar beds and the upper Baymin beds. In the Afghan-Tajik Basin, the Suzak consists of a homogenous gray to greenish-gray mudstone 50 to $200 \mathrm{~m}$ thick with intercalated bituminous mudstone. The Kapter calcareous mudstone beds in the Givar horizon contain combustible bituminous mudstone layers as much as $1.6 \mathrm{~m}$ thick that contain phosphorite, pyrite, and marcasite(?) concretions. The phosphorite nodules are 2 to $5 \mathrm{~cm}$ in size. In the easternmost part of the Afghan-Tajik Basin, the Givar horizon is 6 to $13 \mathrm{~m}$ thick.

The Alay Suite is middle Eocene in age and consists of interbedded limestone, marl, mudstone, and sandstone (Klett and others, 2006). In the Afghan-Tajik Basin, the Alay consists of largely gray limestone and reddish mudstone 30 to $200 \mathrm{~m}$ thick (Klett and others, 2006), although the upper Alay sandstone hosts phosphatic clasts and fossils (Pokryshkin, 1981). Pokryshkin (1981) also reports that commercial phosphate deposits are present in this unit in the Afghan-Tajik Basin, although it is not known whether any of these are considered to occur in or near Afghanistan. 


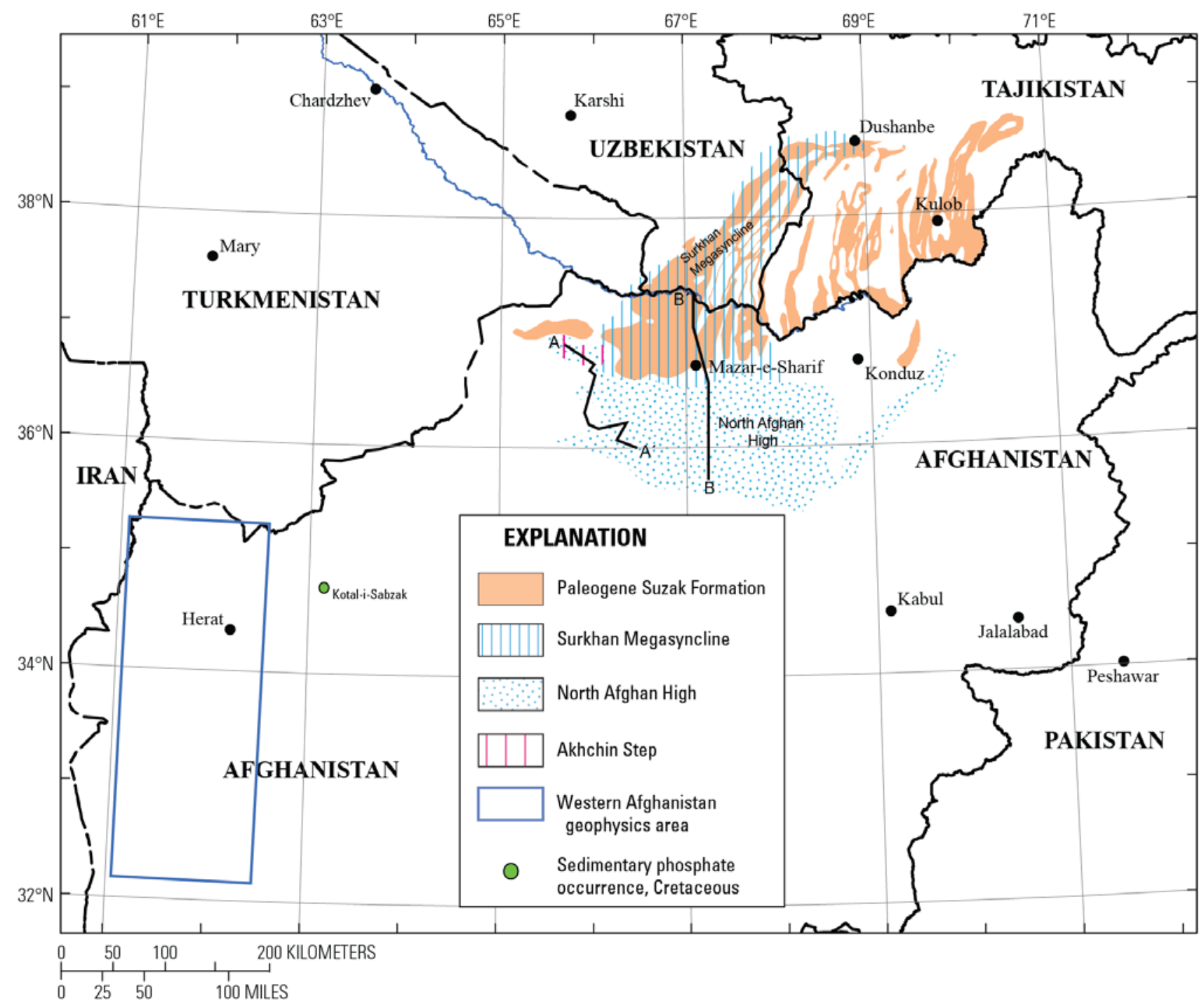

Figure 12. Map showing the areal distribution of Suzak Formation mudstone beds in overriding thrust sheets (from Klett and others, 2006).

\section{Paleogene Sedimentary Phosphate in Uzbekistan, Tajikistan, and Turkmenistan}

\section{Tajik-Fergana Region}

The Tajik-Fergana region is located in southeastern Uzbekistan, much of Tajikistan, and a small part of extreme eastern Turkmenistan. It includes the Tajik and Fergana Basin areas (fig. 11) and the uplifted areas between them. Both basins are characterized by relatively constant subsidence that led to the deposition of large thicknesses of Mesozoic and Cenozoic sedimentary rocks. Subsequent tectonic movement then dislocated these rocks (Il'yashenko, 1967). During the Paleogene, a subbasin of the paleo-Tethys Sea existed in this area that was relatively deeper than to the west in the Kyzyl Kum area and may have limited phosphate deposition (Il'yashenko, 1967). Phosphatic horizons were reported by Il'yashenko (1967) to contain as much as 4 to 22.3 percent $\mathrm{P}_{2} \mathrm{O}_{5}$. 


\section{Fergana Basin}

The information in this section has been largely extracted from Il'yashenko (1967). During the Paleogene, the Fergana Basin was mostly cut off from the open paleo-Tethys Sea by the ChatkalaKuramy Mountains to the west and south, and by the islands and submarine rises that now form the Turkestan, Zaravshan, and Gissar Ranges (fig. 3).

The stratigraphy of the Fergana Basin consists of Triassic to Lower Jurassic continental sedimentary rocks that are overlain by Upper Jurassic marine limestone and lagoonal gypsiferous rocks. Cretaceous red beds overlie these units. The Paleogene section here is as much as $850 \mathrm{~m}$ thick and consists of Paleocene to Oligocene marine sandstone and clayey to sandy calcareous rocks in which granular phosphorites are widespread, especially in the middle Eocene sandstone. Neogene continental deposits overlie the Paleogene rocks.

For the most part, a single phosphorite horizon formed in the Fergana Basin (Eocene). Il'yashenko (1967) reports three phosphate deposits (Isfary, Guzan, Suzak) and several showings (table 1). The middle Eocene phosphorite consists of granular phosphate in the Alay Beds that dip 14 to 25 degrees in an unspecified direction. The phosphate grains are brown to black, 0.1 to $5 \mathrm{~mm}$ in size, and dispersed in marl beds with the sandstone. The thicknesses of the phosphate horizons at Isfary and Suzak are $0.4 \mathrm{~m}$ or more, but the thickness at Guzan was reported as only $0.6 \mathrm{~m}$. Grades in this area are variable and range from 4.9 to 15.8 percent $\mathrm{P}_{2} \mathrm{O}_{5}$. Nodular phosphate is also reported to be present in this area, but its age and distribution was unclear in Il'yashenko (1967).

\section{Tajik Basin}

The stratigraphy of the Tajik Basin area is the same as in the Fergana Basin, although the thicknesses of the units are commonly less in the Fergana Basin. In the Tajik Basin, the Mesozoic sedimentary sequence is as much as $1000 \mathrm{~m}$ thick and the Jurassic sequence is as much as $2500 \mathrm{~m}$ thick. The Lower Cretaceous sedimentary rocks are continental in origin, while the Upper Cretaceous is marine in origin, with the total thickness of Cretaceous strata as much as $2300 \mathrm{~m}$ (Il'yashenko, 1967). The Paleogene sequence here is more than $1000 \mathrm{~m}$ thick.

Within the Paleogene sedimentary rocks is a relatively thick phosphorite that includes several distinct phosphate horizons with elevated grades. Il'yashenko (1967) reports phosphate deposits at Dosmangy, Guliob, Qaratag, Ziddin, and Rivat with additional occurrences in the Gissar Range and Baysuntane Mountains and at Shirabad and Shurasan (Il'yashenko, 1967; Yanshin, 1982). There is a single phosphate horizon at Shirabad and Shurasan, 4 horizons at Dosmangy, 1 or 2 horizons at Qaratag, as many as 9 phosphate horizons at Ziddin, 16 at Guliob, and 3 horizons at Rivat (Il'yashenko, 1967; Rasulov and others, 1990). The beds at Rivat and Guliob dip 25 to 80 degrees in an unspecified direction and the ores can reportedly be beneficiated to 27 percent $\mathrm{P}_{2} \mathrm{O}_{5}$.

The greater Tajik Basin area includes the phosphorite found on the southeastern spurs of the Gissar Range. Here, Paleogene phosphate occurs in four modes (Belenky and others, 1972; Rasulov and others, 1990): (1) at the bottom of the Paleocene sequence in folded sulfate-carbonate strata; (2) in Eocene clay and clay-sand; (3) as a granular-nodule mix in middle Eocene clay; and (4) in Oligocene red-colored sand and clay. The middle Eocene deposits usually contain multiple phosphatic horizons with relatively high phosphorus content.

Brownish grains of granular phosphate occur in marl and clay, with the concentration gradually decreasing upwards at Shurasan, Dostangy, Bandyhand, Derbent, and Guliob. At Sardoba, Aktashy, Dara, and Tandyrcha, nodular phosphate is dominant with nodules $2-4 \mathrm{~cm}$ in diameter occurring in gypsiferous sedimentary units (Rasulov and others, 1990). 


\section{Kara Kalpak - Kyzyl Kum Area}

The second major region of Paleogene phosphogenesis in Central Asia is the Kara Kalpak Kyzyl Kum area that is located in central and western Uzbekistan (fig. 3). During the Mesozoic, this area was relatively stable tectonically. Permian to Triassic claystone and sandstone as much as $2500 \mathrm{~m}$ thick underlie much of the area (Il'yashenko, 1967). These sedimentary rocks are overlain by Lower Jurassic continental coal-bearing rocks that in turn underlie Upper Jurassic calcareous and gypsiferous marine and lagoonal sequences that are as much as $1.3 \mathrm{~km}$ thick. Above this lie Lower Cretaceous rocks consisting largely of sandstone and claystone. Later Cretaceous rocks (Senonian and younger) are composed of limestone and nodular phosphorites. The total Cretaceous sequence here is as much as $2100 \mathrm{~m}$ thick.

Paleogene strata consist largely of marly clay rocks 250 to $1500 \mathrm{~m}$ thick. At the base of the Paleogene, nodular phosphate is widespread. Neogene continental rocks overlie the Paleogene sedimentary rocks (Il'yashenko, 1967).

From the end of the Cretaceous through the Paleogene, this area was covered by a platformal sea that extended well past the boundaries of the Kara Kalpak-Kyzyl Kum area. This sea was open and shallow, with abundant large islands. Il'yashenko (1967) reports that the depth was commonly tens of meters and, less frequently, hundreds of meters based on the geology of the enclosing sedimentary rocks and the probable paleoenvironments attributed to the contained fauna.

Kara Kalpak

The Kara Kalpak area is located to the south and southwest of the Aral Sea. Deposits in this area include Khodzheilin, Chakai Tugai, and Khodzhakul. Some information is also available for the Ketmenchy occurrence (Il'yashenko, 1967). These deposits and showing commonly have one Paleogene phosphate horizon that is 0.1 to $1.0 \mathrm{~m}$ thick that is composed of sandy phosphate pebbles in limestone or, in one case (Khodzhakul), sandstone. Cretaceous phosphate nodule-bearing strata occur at Khodzheilin and Ketmenchy. Phosphate in the lower part of the Paleogene strata is probably the result of erosion of the Upper Cretaceous deposits due to uplift in the area and redeposition followed by cementation with carbonate cement. Exploration in the 1980's resulted in the discovery of granular phosphate at the base of a dark gray marl of probable Eocene age (Mirakhmedov and Palybekov, 1988).

At Khodzheilin, two phosphate horizons are separated by limestone. This Paleogene sequence overlies eroded Campanian-age clays that contain an older, third phosphate horizon at their base.

The phosphorite at Chakai Tugai overlies Turonian sandstone and clay. Chakai Tugai is approximately $17 \mathrm{~km}$ southeast of the town of Nukus. The phosphorite horizon is $0.3 \mathrm{~m}$ thick on average with as much as 8 percent $\mathrm{P}_{2} \mathrm{O}_{5}$. The Paleogene rocks dip 3 to 10 degrees in an unspecified direction and crop out, or are near the surface, over a large area (Il'yashenko, 1967). The cementing limestone is partially decomposed and the phosphate pebbles can be easily separated by screening.

At Khodzhakul, there are also two Paleogene phosphate horizons in host sediments that overlie Turonian sandstone and claystone. The phosphorite consists of phosphate-cemented nuclei, shells, and nodules in the upper Paleogene horizon. This horizon is as much as $0.4 \mathrm{~m}$ thick with 12-15 percent $\mathrm{P}_{2} \mathrm{O}_{5}$ (Il'yashenko, 1967). The pebbles and nodules are $0.5-15 \mathrm{~cm}$ in size, brown, and dull to lustrous with a mineral of the apatite group as a source of the phosphorus.

At the Ketmenchy occurrence, Paleogene phosphorite overlies Campanian-age clays. A second, older phosphorite horizon lies at the base of the Campanian clays. 
Kyzyl Kum

Within the Kyzyl Kum area, phosphorites are found in Paleogene marine sedimentary rocks formed in peripheral basins of the Tethys Sea (Ilyin and Boiko, 1989). These deposits share some characteristics with the better known deposits of similar age in the Near East and North Africa (Yanshin, 1982) and this area may be the most promising phosphate region in Central Asia.

A large number of phosphorite horizons are hosted by Paleocene to Eocene rocks in this area. The Paleogene phosphate strata are not exposed, but have been delineated in several parts of the Kyzyl Kum area through drilling. The base of the Paleogene sedimentary sequence is composed of the lower Paleocene Akdzhar Suite of gypsiferous carbonate sedimentary rocks that are as much as $60 \mathrm{~m}$ thick (Yanshin, 1982). These are overlain by the upper Paleocene Bukhara Suite that exhibits a diverse lithology and is as much as $30 \mathrm{~m}$ thick. This unit is the host to granular phosphate deposits in the western and central part of the Kyzyl Kum area.

The Bukhara Suite rocks are overlain by the lithologically diverse Lower Eocene Suzak Suite. In northern and western Kyzyl Kum, they are composed of 40-50 m of limestone intercalated with black shale and rare phosphate pebbles and grains. In the east and southeast, the suite consists of a lower unit of sandstone, siltstone, and gravel, with an upper unit of clay, sandstone, and coal. Both have phosphatic nodules and grains at their bases (Yanshin, 1982).

The middle Eocene phosphate horizons (Alai Suite) are commonly labeled B, O, I, II, III, IV (Yanshin, 1982; Rasulov and others, 1990). Layers 0, I, and II are grainy, while layers B, III, and IV are gravel-type phosphorite. Layer B represents the top of the middle Eocene or base of the upper Eocene. This horizon is calcareous at Dzhetymtau and Dzheroi-Sardara and argillaceous to the south. The phosphatic horizon is dominantly gravel - pebble phosphorite, $0.1-8.0 \mathrm{~m}$ thick with about 10 percent $\mathrm{P}_{2} \mathrm{O}_{5}$ (Rasulov and others, 1990).

Phosphate layer $\mathrm{O}$ lies below the basal layer with detrital marl separating the units. This horizon is a weakly-cemented granular phosphorite as much as $0.45 \mathrm{~m}$ thick (Rasulov and others, 1990) of probably middle Eocene age. Below this unit lies phosphate layer I, a granular layer of phosphate as much as $3.75 \mathrm{~m}$ thick and composed largely of marl. The phosphate is poorly cemented and composed mostly of organic remains (Rasulov and others, 1990). Layer II lies stratigraphically 8 $12 \mathrm{~m}$ below I, but is otherwise similar to Layer I. Layers I and II are probably middle Eocene in age and these layers appear to be the most promising.

Phosphorite layers III and IV are gravel-pebble phosphate of limited thickness $(<0.35 \mathrm{~m})$ with a grade range of 6.24 to 10.47 percent $\mathrm{P}_{2} \mathrm{O}_{5}$. Layer III is probably middle Eocene according to Rasulov and others (1990). No age was given for Layer IV, but it lies directly on eroded Cretaceous sedimentary rocks. Layer IV may be equivalent to layers 4 and 6 of the Bukhara Suite, according to Rasulov and others (1990). This is the only indication found to date of the relationship between the Paleogene units of Yanshin (1982) and Il'yashenko (1967) and the Eocene units of Rasulov and others (1990). Much of the Eocene phosphorite is reported by Ilyin and Boiko (1989) to be oxidized, with the depth of weathering varying from 20 to $60 \mathrm{~m}$.

Between 1975 and 1980, large phosphorite resources were identified in the Dzhetymtau, Dzheroi-Sardara (fig. 13), Tashkura (fig. 13), Karakat, and other fields. The Dzheroi-Sardara deposits have a reported resource of $200 \mathrm{Mt}_{2} \mathrm{O}_{5}$ (Ilyin and Boiko, 1989) and there is an estimated $439 \mathrm{Mt}$ $\mathrm{P}_{2} \mathrm{O}_{5}$ at Dzhetymtau. 


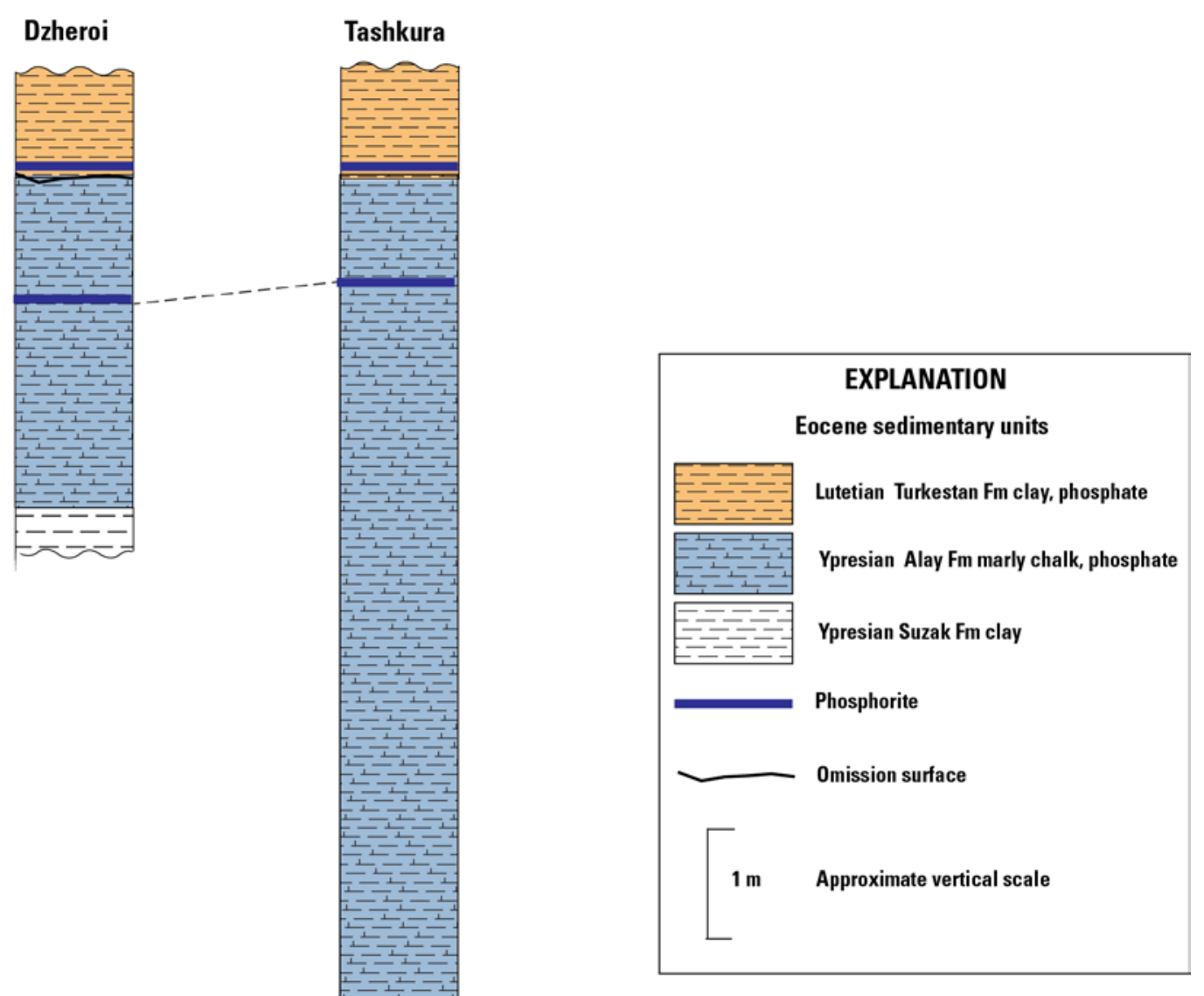

Figure 13. Stratigraphic sections for the Dzheroi and Tashkura phosphate occurrences (deposits) (modified from Janssen and others, 2011). An omission surface marks a temporary halt in deposition, with little or no erosion. $\mathrm{Fm}$, formation.

\section{Paleogene Phosphorite in Iran}

Late Cretaceous to Eocene phosphorite was discovered in Iran in 1954 and resources of Paleocene to Oligocene phosphorite (fig. 14) are estimated at $165 \mathrm{Mt}$ at 20 percent $\mathrm{P}_{2} \mathrm{O}_{5}$ (Notholt and others, 1989b). The main host of the Paleogene phosphorite is the Pabdeh Formation. The base of the Pabdeh is about $140 \mathrm{~m}$ of shale and marl interbedded with limestone and overlain by $74 \mathrm{~m}$ of gray shale interbedded with limestone and some phosphorite (Salehi, 1989). Above this is thinly bedded limestone containing some chert, that in turn is overlain by $82 \mathrm{~m}$ of dark shale. The uppermost part of 
the Pabdeh Formation is composed of as much as $459 \mathrm{~m}$ of thinly bedded argillaceous limestone interbedded with shale.

Paleogene-age phosphorite deposits and occurrences are the most common in the vicinity of Afghanistan. In places, such as the Kara Kalpak area of Uzbekistan, the $\mathrm{P}_{2} \mathrm{O}_{5}$ grades and phosphorite thickness are sufficient to form a notable resource. However, it is not clear from the available data whether the phosphorite closer to the Afghanistan border, and likely to extend into Afghanistan, is of adequate grade, thickness or continuity to have development potential. Additional sampling, more detailed maps, paleogeographic reconstructions, and geophysical studies could help clarify the potential.

\section{Neogene Sedimentary Phosphate}

Only five sedimentary phosphate occurrences in the countries bordering Afghanistan are believed to be Neogene in age - three in Iran and two in Pakistan.

\section{Neogene Sedimentary Phosphate in Iran}

In Afghanistan, marine conditions still prevailed during the early Miocene, but by the middle Miocene continental deposition was dominant (Ghorbani, 2013). The three Neogene sedimentary occurrences in Iran are all located in the extreme northwest of the country, west of the Caspian Sea. The Dareh-e-Gorg phosphate occurrence is found in clay and marl of the Miocene Maragheh Formation where one sample reported 35.18 percent $\mathrm{P}_{2} \mathrm{O}_{5}$. There is no additional information available on the other two occurrences reported to be hosted by Neogene sediments.

\section{Neogene Sedimentary Phosphate in Pakistan}

The two occurrences in Pakistan are located in the Punjab Province. The Dadu occurrence is in the Gaj Formation and is reported to contain 10-15 percent $\mathrm{P}_{2} \mathrm{O}_{5}$ (Asrarullah, 1980). The Fatehjang phosphate occurrence is found in sandstone, shale, and grit sequence of the Miocene Murree Formation. At this location, the $\mathrm{P}_{2} \mathrm{O}_{5}$ content is reported to be between 10 and 20 percent (Ali, 1974).

\section{Igneous Phosphate- Carbonatites}

There are three known phosphate occurrences in the study area that are associated with carbonatite. These deposits are Khanneshin in Afghanistan, Loe Shilman in Pakistan and Afghanistan, and Qaratag in Tajikistan. Carbonatites may contain deposits of iron, copper, titanium, zirconium, vermiculite, rare earths, uranium, and other commodities, as well as phosphate.

\section{Carbonatite in Afghanistan}

The Koh-e-Khanneshin (Khanneshin) carbonatite in Helmand Province consists of Quaternary carbonate-rich intrusive and extrusive igneous rocks with three small outcrops of leucite, phonolite, and leucitite (Tucker and others, 2011a). An area of alkivite tuffs and lava flows in the southern part of the complex forms a prospective area for phosphate that is also enriched in magnetite (Alkhazov and others, 1978; Tucker and others, 2011b); the area also has volcanics that are described as massive, fragmental, horizontal amygdaloidal flows and tuffs with a thickness of $10 \mathrm{~m}$. Eriomenko and Chmyriov (1975) reported eight zones with apatite mineralization within the carbonatite complex at Khanneshin; four of these fall in the area shown as prospective by Tucker and others (2011a,b). Alkhazov and others (1978) reported phosphate grades varying from 1 to 8.3 percent $\mathrm{P}_{2} \mathrm{O}_{5}$. There are no identified resources or reserves 


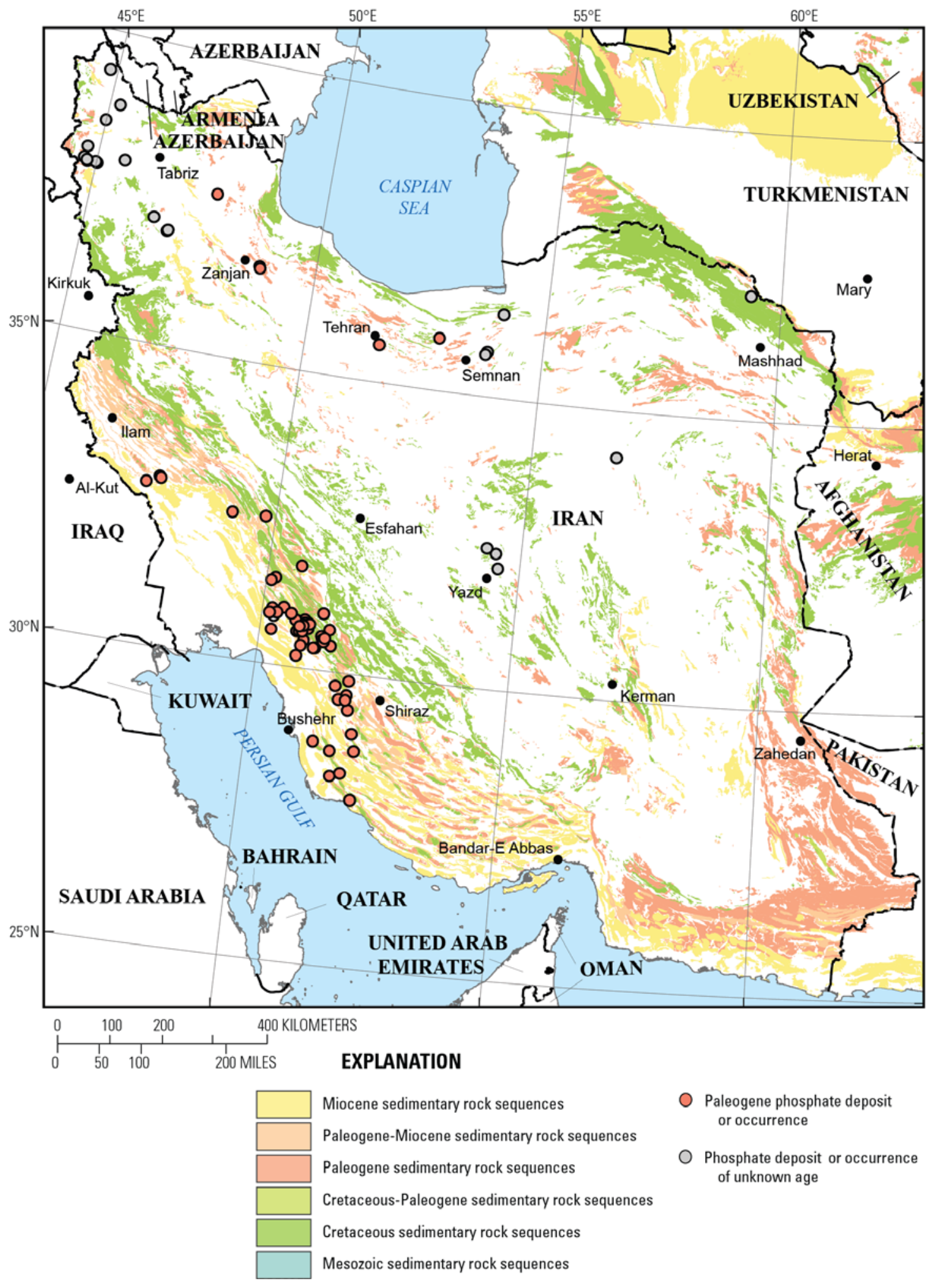

Figure 14. Map of the distribution of Paleogene sedimentary phosphate in Iran. 
for the Khanneshin occurrence. The reader is referred to Tucker and others (2011a,b), Tucker and others (2012), and Peters and others (2007).

In addition to Khanneshin, the Loe Shilman carbonatite on the Pakistan-Afghanistan border is considered to have potential for phosphate. This occurrence is discussed more fully in the next section.

\section{Carbonatite in Pakistan}

The Loe Shilman phosphate deposit is found in a carbonatite complex composed of sill-like carbonatite bodies and syenites emplaced in metasedimentary rocks of the Landi Kotal Formation about $80 \mathrm{~km}$ northwest of Peshawar at the Pakistan-Afghanistan border. Within Pakistan, the phosphate-bearing carbonatite body is approximately $1.8 \mathrm{~km}$ long and 100-200 m thick (Appleton and Notholt, 2002). The carbonatite was emplaced along an east-west trending fault zone separating Paleozoic rocks in the north from Precambrian(?) metasediments in the south (Hasan and Asrarullah, 1989; Ullah, 2006). There is evidence of alkali metasomatism or fenitization of the host metasediments (Ullah, 2006).

The Loe Shilman carbonatite has potential for economic niobium, rare earth, and phosphate mineralization (Ullah, 2006). Hasan and Asrarullah (1989) report a resource of $59 \mathrm{Mt}$ at 4.4 percent $\mathrm{P}_{2} \mathrm{O}_{5}$ exposed at the surface, and $142 \mathrm{Mt}$ at 5.5 percent $\mathrm{P}_{2} \mathrm{O}_{5}$ in the subsurface to a depth of $200 \mathrm{~m}$. This estimate likely refers only to the part of the complex within Pakistan.

\section{Igneous Phosphate- Kiruna and Other}

Within Iran, apatite is reported to occur in 19 subeconomic to economic deposits in igneous rocks other than carbonatite. These deposits include Kiruna-type deposits as well as Ti-apatite deposits associated with alkaline granites. The only currently-producing phosphate mine in Iran is Esfordi, which has been classed as a Kiruna- or iron oxide-apatite (IOA)- type deposit (Stosch and others, 2011).

The IOA- or Kiruna-type deposits have been documented as having formed from the Proterozoic to the Tertiary. They are commonly associated with calc-alkaline volcanic rocks and Na$\mathrm{K}-\mathrm{Ca}(\mathrm{Mg})-\mathrm{Fe}-\mathrm{P}$ (REE) alteration on a deposit- to regional-scale (Stosch and others, 2011). Although in some areas, these deposits are genetically or spatially associated with deposits of copper \pm gold, but other areas, such as Iran's Bafq District, have no association with copper-gold deposits (Stosch and others, 2011).

\section{IOA-Kiruna Deposits in Iran}

The Bafq District in central Iran hosts major iron oxide-apatite deposits that occur in Early Cambrian felsic volcanic tuffs and volcanosedimentary sequences and locally intruded by gabbroic to granitic, trachytic and doleritic bodies (Jami and others, 2007; Stosch and others, 2011; Ghorbani, 2013). These rocks are variably assigned to the Cambrian Volcanic-Sedimentary Unit or to the Saghand or Rizu Formations which form part of the unit (Torab, 2008). There are more than 34 major magnetite-apatite occurrences in the Bafq District with $750 \mathrm{Mt}$ to more than 2 billion metric tons (Bt) of iron ore (Jami, 2005; Jami and others, 2007). These deposits are commonly classified as IOA or Kiruna iron-apatite deposits, although the deposits are complex and other classifications have been proposed. It is clear that separation of an iron oxide melt and hydrothermal processes dominated by alkali metasomatism played large roles in the development of these deposits (Jami, 2005; Jami and others, 2007; Stosch and others, 2011; Mokhtari and others, 2013). In addition to magnetite, hematite, and apatite, the deposits of the Bafq District are enriched in rare earth elements (REE). 
Daliran (2002) divided the Bafq District deposits into two groups. The first group are concordant lenses of phosphate-poor iron oxides that have gradational boundaries. The second group is composed of massive bodies of apatite-magnetite \pm hematite with apatite-rich zones. Deposits in the second group include Choghart, Sechahun, Chadormalu and Esfordi (Jami, 2005).

The Esfordi apatite-magnetite deposit is one of the most P-rich deposits in the Bafq District. It has a resource of $17 \mathrm{Mt}$ at 13.5 percent $\mathrm{P}_{2} \mathrm{O}_{5}$ and produces 103,000 metric tons of apatite concentrate each year (Daliran, 2002; Jami, 2005). It is hosted by a sequence of early Cambrian volcanicsedimentary unit (probably the Saghand Formation) which formed in a continental margin tectonic regime (fig. 15). The formation is composed of rhyolitic lavas, pyroclastic and epiclastic rocks, intercalated carbonates, and local subvolcanic granites (Jami, 2005).

The Esfordi ore body is a lenticular stratabound ore body as much as $500 \mathrm{~m}$ long that dips gently and has a well-developed mineral zone pattern (Jami, 2005). In the deposit, an iron oxide-rich core is composed of magnetite with a more hematitic rim. The phosphate ore body overlies the core and contains massive and brecciated apatite bodies. A zone of apatite-bearing veins and disseminations surrounds the iron oxide and phosphate ore bodies and extends into the overlying volcaniclastic rocks. The ore zones are surrounded by Ca-rich alteration which extends as much as $100 \mathrm{~m}$ into the volcaniclastic rocks (Jami, 2005). Studies by Jami (2005) show a paragenetic sequence with four generations of apatite.

The Gazestan deposit, which is approximately $78 \mathrm{~km}$ east of Bafq, is similar to the Esfordi deposit in terms of its elevated phosphate content. The deposit has tens of millions of metric tons of ore with a mean grade of 10 to 15 percent $\mathrm{P}_{2} \mathrm{O}_{5}$ (Esfahani and Asghari, 2013). Esfahani and Asghari (2013) assign the host carbonate sediments, shale, sandstone, and volcanic rocks to the Rizu Formation. These rocks are intruded by gabbroic, dioritic, and diabasic stocks and dikes. The phosphate and iron mineralization is found in green rocks with unspecified "acidic components". The apatite mineralization occurs as lens, veins, and nodules in strongly chloritized pyroxene diabase. The deposit is also reported to have $>1.5$ percent REE in apatite (Esfahani and Asghari, 2013).

Other occurrences and deposits in the Bafq District, such as Chadormalu (Ghorbani, 2003), have elevated phosphate contents, but no details were found on the geology of the phosphate occurrence or on the grade. It does not appear that phosphate is being produced as a byproduct at any of the active iron mines in the district.

\section{Ti-P Deposits in Iran}

In 1996, the Ghara-aghaj Ti-P deposit was discovered about $36 \mathrm{~km}$ northwest of Urumieh (Urmia) in the far northwestern part of Iran (Mehdilo and Irannajad, 2012; Ghorbani, 2013). The mineralization is hosted in an intrusive complex that intrudes Precambrian rocks and includes ultrabasic rocks such as wehrlite, lherzolite, and clinopyroxenite, as well as diorite and gabbro (Yaghubpur and others, 2007). The degree of mineralization is highest in the ultrabasic rocks. The age of the intrusive rocks is unclear, but is probably older than upper Permian (Yaghubpur and others, 2007). Ore minerals include ilmenite, magnetite, apatite, titanomagnetite, ulvöspinel, and hercynite. Ghorbani (2013) reports a subeconomic resource of $80 \mathrm{Mt}$ of ore at 4 percent $\mathrm{P}_{2} \mathrm{O}_{5}$; Mehdilo and Irannajad (2012) report a resource of $102 \mathrm{Mt}$ at 2.3 percent $\mathrm{P}_{2} \mathrm{O}_{5}$. Phosphate is most likely to be a byproduct of titanium production from this deposit. 


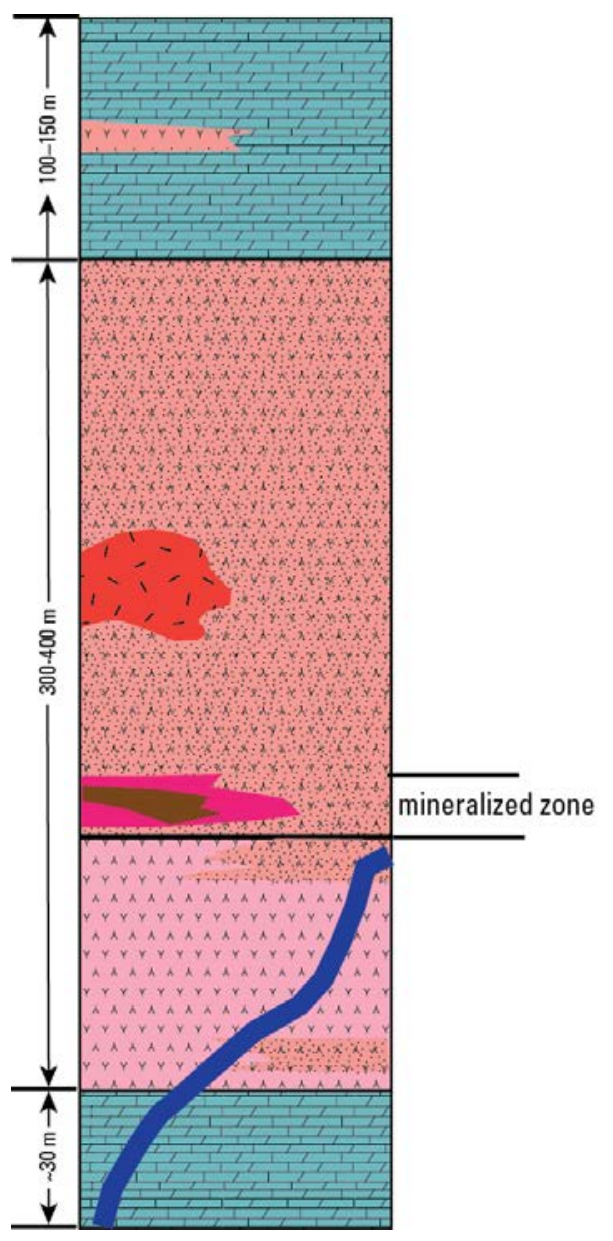

\section{EXPLANATION}

\begin{tabular}{|l|l}
\hline & Apatite ore \\
\hline & Iron ore \\
\hline & Ash flow tuff, unwelded with with lenses of \\
\hline & Limestone and dolomite \\
\hline & Dolerite dike
\end{tabular}

Figure 15. Schematic stratigraphic sequence of the lithology of the Cambrian Volcanic-Sedimentary Unit (Saghand Formation) at the Esfordi phosphate deposit.

\section{Geographic Information System (GIS)}

Much of the basic data compiled for the production of this report is included in the accompanying GIS. The GIS is composed of two distinct databases: (1) a database of phosphate deposits and occurrences, and (2) a compilation of lithologies that might host undiscovered phosphate in one of the deposit types found in Afghanistan, Iran, Pakistan, Tajikistan, Turkmenistan, or Uzbekistan. A limited amount of data for the western part of Xinjiang Province in China is included in both datasets.

The phosphate deposits and occurrences database that has been compiled for this study contains more than 400 records with 30 fields of data (table 3). Some sites are duplicated within the database if more than one age of mineralization is present. Records may be present for sites and for their host districts or deposits. In addition, because of differences in the transliteration and translation of names from Russian, Persian, or other languages to English, some duplicate sites may not have been identified. Locations could not be determined accurately for many of the sites, but the locations are believed to be acceptable at 1:1,000,000 scale. More than 150 of the sites are known to occur in Paleocene sedimentary sequences and many, if not most, of the records without a specific age of mineralization are likely to occur in Paleogene host rocks. Other large subsets of data include 
sedimentary phosphate in sedimentary rocks of Late Devonian and Early Cambrian ( \pm latest Proterozoic) sequences. Deposits were classified as sedimentary or igneous, although carbonatiterelated deposits were broken out and some modifying terms such as alkaline, biogenic or redeposited were added when appropriate. Kiruna-type deposits were also distinguished.

Selected lithologies were compiled and grouped from fourteen 1:500,000- and 1:1,000,000scale geologic maps covering parts of the study area (table 4). Lithologies from the 14 maps were then grouped into common units by lithology and (or) age. Sedimentary rocks were grouped by age or age range. Igneous rocks were grouped by type and (or) age to facilitate determination of permissiveness for phosphate deposits found in the study area. These groupings are given in table 5. These data are appropriately used at 1:1,000,000 scale.

\section{Discussion and Summary}

This study looked at the potential for phosphate deposits in Afghanistan by investigating the deposits and occurrences in Afghanistan and the surrounding region. While there is potential for an economically viable phosphate deposit to be discovered in Afghanistan, a significant (in terms of people, money, time) exploration effort is probably needed to identify such deposits and there is always the potential for failure or that a deposit cannot be economically developed.

Four of the factors that decrease the potential for discovery of an economic deposit include:

- Known deposit sizes in the study area are small (table 1) on average compared to deposits in North Africa or the United States;

- Known deposit grades are relatively low on average (table1);

- Geology is complex in many areas; and

- Many potential areas are remote or difficult to access and infrastructure for these areas may need to be developed to exploit any deposit.

Many deposits in the major phosphate producing areas such as Morocco and the western United States contain hundreds of millions to billions of metric tons of phosphate-bearing rock and typical grades of 25 percent $\mathrm{P}_{2} \mathrm{O}_{5}$ or better. In the study area, only Behbehan (165 Mt, Iran, Paleogene), Garaaghaj (102 Mt, Iran, igneous), Lar (210 Mt, Iran, Paleogene), Rizrud (160 Mt, Iran, Paleogene), Dzheroi-Sardara (304 Mt, Uzbekistan, Paleogene, includes Tashkura), and the Panjakent area (2 Bt, Tajikistan, Paleogene) are reported to contain more than $100 \mathrm{Mt}$ of ore. Of these, only Behbehan (20 percent) and Dzheroi-Sardara (19 percent) have grades greater than 10 percent $\mathrm{P}_{2} \mathrm{O}_{5}$. Lar has a reported grade of 10.5 percent $\mathrm{P}_{2} \mathrm{O}_{5}$ and the others have significantly lower grades. While some low-grade ores can be relatively cheaply beneficiated, this is not a factor that can be reliably predicted.

The commonly complicated geologic history of areas in Afghanistan has contributes to the difficulty of identifying possible economic deposits of phosphate. Tectonics has probably contributed to the disruption and loss of deposits by exposing them to erosion or deep burial and by breaking larger, more extensive, deposits into small deposits. Examples of this are Cambrian deposits in Pakistan that are commonly small, disrupted, and truncated by faults. Paleogene rocks in the AfghanTajik Basin have been down dropped to depths of greater than $2 \mathrm{~km}$ just north of the Afghan High, uplifted and eroded over some topographic highs (fig. 16), found at depths of as much as $1 \mathrm{~km}$, and eroded in other areas west of the Afghan High (fig. 17).

Overall, for the different categories of deposits, igneous deposits tend to be low grade, but these can still be viable deposits, especially when other commodities are produced in tandem with phosphate. The two known carbonatite deposits at Khanneshin and Loe Shilman therefore have some potential, but require additional study and exploration. 
Table 3. Data fields in phosphate sites database.

\begin{tabular}{|c|c|}
\hline Field Name & Description \\
\hline ID_No & Record number; unique identification number for phosphate site record. \\
\hline Country & Country in which site is located. \\
\hline Province & Province or state in which site is located. \\
\hline Name & Site name. \\
\hline Name_other & Alternative site name(s). \\
\hline Latitude & Latitude in decimal degrees; positive number represents latitude north of the equator. \\
\hline Longitude & Longitude in decimal degrees; positive represents longitude east of the Greenwich meridian. \\
\hline Loc_Notes & Additional location information. \\
\hline Loc_Refs & $\begin{array}{l}\text { Abbreviated citation for source reference for location (with respect to latitude and longitude); full } \\
\text { citation is provided in the standalone file geodatabase table "Citations." }\end{array}$ \\
\hline Mzn_Area & $\begin{array}{l}\text { Name of area, district, deposit, mountain range or other location in which site occurs, if reported } \\
\text { in source reference(s). }\end{array}$ \\
\hline & $\begin{array}{l}\text { Site status. "Deposit" is listed for sites with known resources/reserves of phosphate, or is a } \\
\text { producer or past producer of phosphate. "Occurrence" is listed for sites that do not have known } \\
\text { resources/reserves and are not a current or past producer of phosphate. "Showing" is for }\end{array}$ \\
\hline Status & occurrences where age of mineralization, host, and (or) deposit type are not known. \\
\hline Commods & $\begin{array}{l}\text { Significant commodities present, queried where uncertain. Listed in perceived order of } \\
\text { (economic) significance, based on source references. }\end{array}$ \\
\hline Dep_Type & Phosphate deposit type(s) most likely to be present, queried where uncertain. \\
\hline Phos_Form & Form(s) of phosphate mineralization, queried where uncertain. \\
\hline Age_Ma & Chronologic age of mineralization. \\
\hline MznAge_Max & $\begin{array}{l}\text { Oldest geologic age of potash mineralization, queried where uncertain. Listed in the format Era- } \\
\text { System-Series-Stage, where known. } \\
\text { Youngest geologic age of potash mineralization, queried where uncertain. Listed in the format }\end{array}$ \\
\hline MznAge_Min & Era-System-Series-Stage, where known. \\
\hline HostAge_Max & $\begin{array}{l}\text { Oldest geologic age of host rock, queried where uncertain. Listed in the format Era-System- } \\
\text { Series-Stage, where known. }\end{array}$ \\
\hline HostAge_Min & $\begin{array}{l}\text { Youngest geologic age of host rock, queried where uncertain. Listed in the format Era-System- } \\
\text { Series-Stage, where known. }\end{array}$ \\
\hline Host_Lith & Host rock lithology; multiple lithologies are comma-delimited. \\
\hline Host_Fm & Formal or informal name of host rock formation or other name, queried where uncertain. \\
\hline Minerals & Significant minerals and materials known to be present, queried where uncertain. \\
\hline Geol_Notes & Additional geologic information. \\
\hline Anal_Data & Reported analytical data; en dash indicates range of values. \\
\hline Prod_Status & Known status with respect to being a phosphate producer. \\
\hline First_Prod & Year of first production. \\
\hline Cum_Prod & Reported cumulative production. \\
\hline Rsv_Res & $\begin{array}{l}\text { Reported reserve and (or) resource data. Multiple entries are numbered and delimited by } \\
\text { semicolons, numbers correspond to those used in "RsvRes_refs" field. } \\
\text { Abbreviated citation(s) for source reference(s) used in compiling the reserve and resource data. } \\
\text { Multiple citations are numbered and delimited by semicolons, numbers correspond to those } \\
\text { used in "RsvRes" field. Full citations are provided in the standalone file geodatabase table }\end{array}$ \\
\hline RsvRes_Refs & "Citations." \\
\hline Gen_Notes & Additional information. \\
\hline All_Refs & $\begin{array}{l}\text { Abbreviated citation(s) for source reference(s) used in compiling all data; multiple citations are } \\
\text { delimited by semicolons. Full citations are provided in the standalone file geodatabase table } \\
\text { "Citations." }\end{array}$ \\
\hline
\end{tabular}


Among the sedimentary phosphate deposits, Cambrian deposits similar to those in the Abbottabad area of Pakistan have the potential to occur in adjacent areas of Afghanistan. However, these deposits will tend to be small and of variable grade due to tectonism in the area. While Ordovician phosphate occurrences were identified in the study area, the identified resources (table 1) are small and low grade. Ordovician rocks in Afghanistan are not considered to be a likely host of mineralization. Devonian sedimentary deposits are possible as they are known in Iran, but none of the data found for this study shows that phosphate has been identified in any Devonian sediments.

Exposures of Devonian sediments in Afghanistan are relatively limited, so any potential deposits are likely to be covered and difficult to discover.

The most likely rocks to host a discoverable and possibly economic phosphate deposit are the Cretaceous and Paleogene sediments. There is an identified occurrence of phosphate in Cretaceous rocks in Afghanistan. However, the only identified Cretaceous resource in the study area is the small deposit at Sheik Habil, Iran which has a good grade (22 percent $\left.\mathrm{P}_{2} \mathrm{O}_{5}\right)$, but a small size of only $1 \mathrm{Mt}$.

Paleogene rocks seem to offer the best potential for discovery of a phosphate deposit in Afghanistan. Phosphate is known to occur in Paleogene sediments in the Afghan-Tajik Basin in Afghanistan and Paleogene sedimentary deposits are widespread in Iran, Tajikistan, and Uzbekistan in the sediments associated with the Afghan-Tajik and Amu Darya Basins. That said, it is likely that any deposits would have minimal or no outcrop. It is also possible that any significant mineralization would lie too deep to extract.

It should also be noted that regional geophysics identified six possible areas where phosphate may lie near the surface (fig. 18). If there is mineralization present at these sites, it is likely Cretaceous or Paleogene in age.

Table 4. Map sources for lithologies used in study.

\begin{tabular}{|c|c|c|}
\hline $\begin{array}{l}\text { Part of Study Area Covered by } \\
\text { Map }\end{array}$ & Map Scale & Map \\
\hline Afghanistan & $1: 500,000$ & $\begin{array}{l}\text { Map of mineral resources of Afghanistan (Abdullah and Chmyriov, } \\
\text { 1977) }\end{array}$ \\
\hline Afghanistan & $1: 850,000$ & $\begin{array}{l}\text { Geologic and mineral resource map of Afghanistan (ver. 2) (Doebrich } \\
\text { and Wahl, 2006) }\end{array}$ \\
\hline & & $\begin{array}{l}\text { Geological map of Xinjiang Uygur Autonomous Region of the } \\
\text { People's Republic of China (Xinjiang Bureau of Geology and }\end{array}$ \\
\hline China, Xinjiang Province & $1: 500,000$ & Mineral Resources, 1993) \\
\hline Iran & $1: 1,000,000$ & Geological map of Iran (Huber,1978) \\
\hline Pakistan & $1: 1,000,000$ & Geological map of Pakistan (Qureshi and others, 1993) \\
\hline Tajikistan & $1: 1,000,000$ & Novobod, Map of pre-Quaternary rocks (Vlasov and others, 1989) \\
\hline $\begin{array}{l}\text { Tajikistan, Turkmenistan, } \\
\text { Uzbekistan }\end{array}$ & $1: 1,000,000$ & Dushanbe, Map of pre-Quaternary $r$ \\
\hline Tajikistan, Uzbekistan & $1: 1,000,000$ & $\begin{array}{l}\text { Tashkent, Map of pre-Quaternary rocks (Klishevich and others, 1990) } \\
\text { Turkestan, Map of pre-Quaternary rocks (Pyanovskaya and others, }\end{array}$ \\
\hline Tajikistan, Uzbekistan & $1: 1,000,000$ & 1979) \\
\hline Turkmenistan & $1: 500,000$ & Geological map of Turkmenistan (Mirzakhanov, 1989) \\
\hline Turkmenistan, Uzbekistan & $1: 1,000,000$ & Krasnovodsk, Map of the pre-Quaternary rocks (Bikbaeva, 1994) \\
\hline Turkmenistan, Uzbekistan & $1: 1,000,000$ & Nukus, Map of the pre-Quaternary rocks (Smolko and others, 1976) \\
\hline Uzbekistan & $1: 1,000,000$ & $\begin{array}{l}\text { Guryev, Map of pre-Quaternary rocks (Magretova and others, 1982) } \\
\text { Kazalinsk, Map of pre-Quaternary rocks (Petrova and Magretova, }\end{array}$ \\
\hline Uzbekistan & $1: 1,000,000$ & 1987) \\
\hline
\end{tabular}


Table 5. Potential phosphate-bearing host lithologies compiled and categorized from fourteen 1:500,000- and 1:1,000,000-scale geologic maps.

\begin{tabular}{|c|c|}
\hline Unit & Description \\
\hline $\mathrm{c}$ & Carbonatite-related rocks (Permian-Quaternary) \\
\hline $\mathrm{Cm}$ & $\begin{array}{l}\text { Cambrian rocks-Limestone, sandstone, dolomite, shale, siltstone, chert, phosphorite, and (or) } \\
\text { conglomerate, with volcanic rocks and tuffs locally present. }\end{array}$ \\
\hline $\mathrm{CmO}$ & $\begin{array}{l}\text { Cambrian-Ordovician sedimentary rocks-Calcareous and siliceous shale, claystone, siltstone, } \\
\text { limestone, dolomite, sandstone, and (or) conglomerate }\end{array}$ \\
\hline $\mathrm{D}$ & $\begin{array}{l}\text { Devonian rocks-Undifferentiated limestone, dolomite, shale, sandstone, siltstone, conglomerate, and } \\
\text { (or) chert, with volcanic rocks, tuff, and metasedimentary rocks locally present. }\end{array}$ \\
\hline Dc & $\begin{array}{l}\text { Devonian-Carboniferous rocks-Predominantly marine limestone, dolomite, shale, sandstone, marl, and } \\
\text { (or) chert, with conglomerate, volcanic rocks, and tuff locally present. }\end{array}$ \\
\hline DP & $\begin{array}{l}\text { Devonian-Permian-Undifferentiated limestone, sandstone, siliceous shale, and (or) dolomite, with } \\
\text { marl, siltstone, volcanic flows and tuff, and (or) conglomerate locally present. }\end{array}$ \\
\hline Eo & $\begin{array}{l}\text { Eocene rocks-Sandstone, siltstone, limestone, and (or) marl, with claystone, phosphorite, tuff or } \\
\text { volcanic flows, conglomerate, shale, gypsum, and (or) flysch locally present. }\end{array}$ \\
\hline EoMio & $\begin{array}{l}\text { Eocene-Miocene sedimentary rocks - Conglomerate, sandstone, limestone, with intercalated siltstone } \\
\text { and gypsum locally present. }\end{array}$ \\
\hline EoOlig & $\begin{array}{l}\text { Eocene-Oligocene rocks-Claystone, limestone, siltstone, and (or) sandstone, with local marl, dolomite, } \\
\text { shale, gypsum, conglomerate, and (or) volcanic rocks. }\end{array}$ \\
\hline $\mathrm{gd}$ & Intrusive rocks - Granite, granodiorite and related rocks (Carboniferous-Cenozoic). \\
\hline $\mathrm{gg}$ & Intrusive rocks-Gneiss-granite, granite, plagiogranite (Proterozoic). \\
\hline $\mathrm{JK}$ & Jurassic-Cretaceous sedimentary rocks-Limestone, clastic sedimentary rocks \\
\hline $\mathrm{K}$ & $\begin{array}{l}\text { Cretaceous rocks-Undifferentiated sedimentary rocks, largely composed of sandstone, conglomerate, } \\
\text { limestone, and (or) marl, with siltstone, shale, gypsum, flysch, and (or) volcanic rocks locally present. }\end{array}$ \\
\hline $\mathrm{Kl}$ & $\begin{array}{l}\text { Lower Cretaceous rocks-Undifferentiated sedimentary rocks, largely composed of sandstone, } \\
\text { claystone, limestone, marl, with conglomerate, gypsum, dolomite, phosphorite, celestite, and minor } \\
\text { volcanic rocks locally present. }\end{array}$ \\
\hline Kpe & $\begin{array}{l}\text { Upper Cretaceous-Paleogene sedimentary rocks-Predominantly limestone, with some marl, dolomite, } \\
\text { sandstone, siltstone, gypsum, and (or) conglomerate. }\end{array}$ \\
\hline $\mathrm{Ku}$ & $\begin{array}{l}\text { Upper Cretaceous rocks-Undifferentiated sedimentary rocks, largely composed of sandstone, } \\
\text { claystone, siltstone, marl, limestone, and (or) chalk, with phosphorite, gypsum, conglomerate, shale, } \\
\text { and (or) volcanic flows and tuff locally present }\end{array}$ \\
\hline Mio & $\begin{array}{l}\text { Miocene rocks-Marl, limestone, claystone, siltstone, and (or) sandstone, with conglomerate, gypsum, } \\
\text { chert, dolomite, or volcanic rocks locally present. }\end{array}$ \\
\hline $\mathrm{ms}$ & Metasedimentary and other metamorphic rocks, undifferentiated. \\
\hline $\mathrm{N}$ & $\begin{array}{l}\text { Neogene rocks-Undifferentiated sedimentary rocks, composed largely of marl limestone, claystone, } \\
\text { siltstone, and (or) sandstone, with conglomerate, gypsum, chert, dolomite, or volcanic rocks locally } \\
\text { present. }\end{array}$ \\
\hline $\mathrm{O}$ & $\begin{array}{l}\text { Ordovician rocks-Sandstone, siltstone, limestone, and (or) shale, with conglomerate, metasedimentary } \\
\text { rocks, tuffs, and (or) marl locally present. }\end{array}$ \\
\hline Olig & $\begin{array}{l}\text { Oligocene sedimentary rocks-Predominantly claystone, siltstone, and (or) limestone, with some } \\
\text { sandstone, marl, flysch, conglomerate. }\end{array}$ \\
\hline OligMio & Oligocene-Miocene sedimentary rocks-Limestone, marl, sandstone. \\
\hline OS & $\begin{array}{l}\text { Ordovician-Silurian rocks-Undifferentiated limestone, dolomite, siltstone metasedimentary rocks, and } \\
\text { (or) tuff }\end{array}$ \\
\hline $\mathrm{Pal}$ & $\begin{array}{l}\text { Paleocene rocks-Limestone; also sandstone, claystone, siltstone, marl, phosphorite, and (or) } \\
\text { conglomerate, with lava flows and tuff locally present. }\end{array}$ \\
\hline PalEo & $\begin{array}{l}\text { Paleocene-Eocene sedimentary rocks-Claystone, marl, limestone, shale siltstone, sandstone, with red- } \\
\text { colored gypsum and conglomerate locally present }\end{array}$ \\
\hline $\mathrm{Pe}$ & $\begin{array}{l}\text { Paleogene sedimentary rocks - Clay, siltstone, sandstone, marl, limestone dolomite, gypsum, flysch, } \\
\text { conglomerate. }\end{array}$ \\
\hline
\end{tabular}




\begin{tabular}{|l|l|}
\hline \multicolumn{1}{|c|}{ Unit } & \multicolumn{1}{c|}{ Description } \\
\hline SD & $\begin{array}{c}\text { Silurian-Devonian rocks-Undifferentiated siltstone, limestone, sandstone, and (or) shale, with volcanic } \\
\text { rocks, tuff, and metasedimentary rocks locally present. }\end{array}$ \\
\hline um & $\begin{array}{c}\text { Ultramafic rocks, undifferentiated-Includes peridotite, dunite, serpentinite, and pyroxenite; some } \\
\text { sequences include gabbro, wehrlite, lherzolite, amphibolite, and (or) norite. }\end{array}$ \\
\hline $\mathrm{V}$ & Volcanic rocks-Acidic tuff and volcanic rocks, keratophyre, quartz porphyry, some sedimentary rocks. \\
\hline $\mathrm{Z}$ & Neoproterozoic rocks-Undifferentiated sedimentary and metasedimentary rocks. \\
\hline ZCm & Neoproterozoic-Cambrian rocks-Limestone, dolomite, metasedimentary rocks. \\
\hline
\end{tabular}

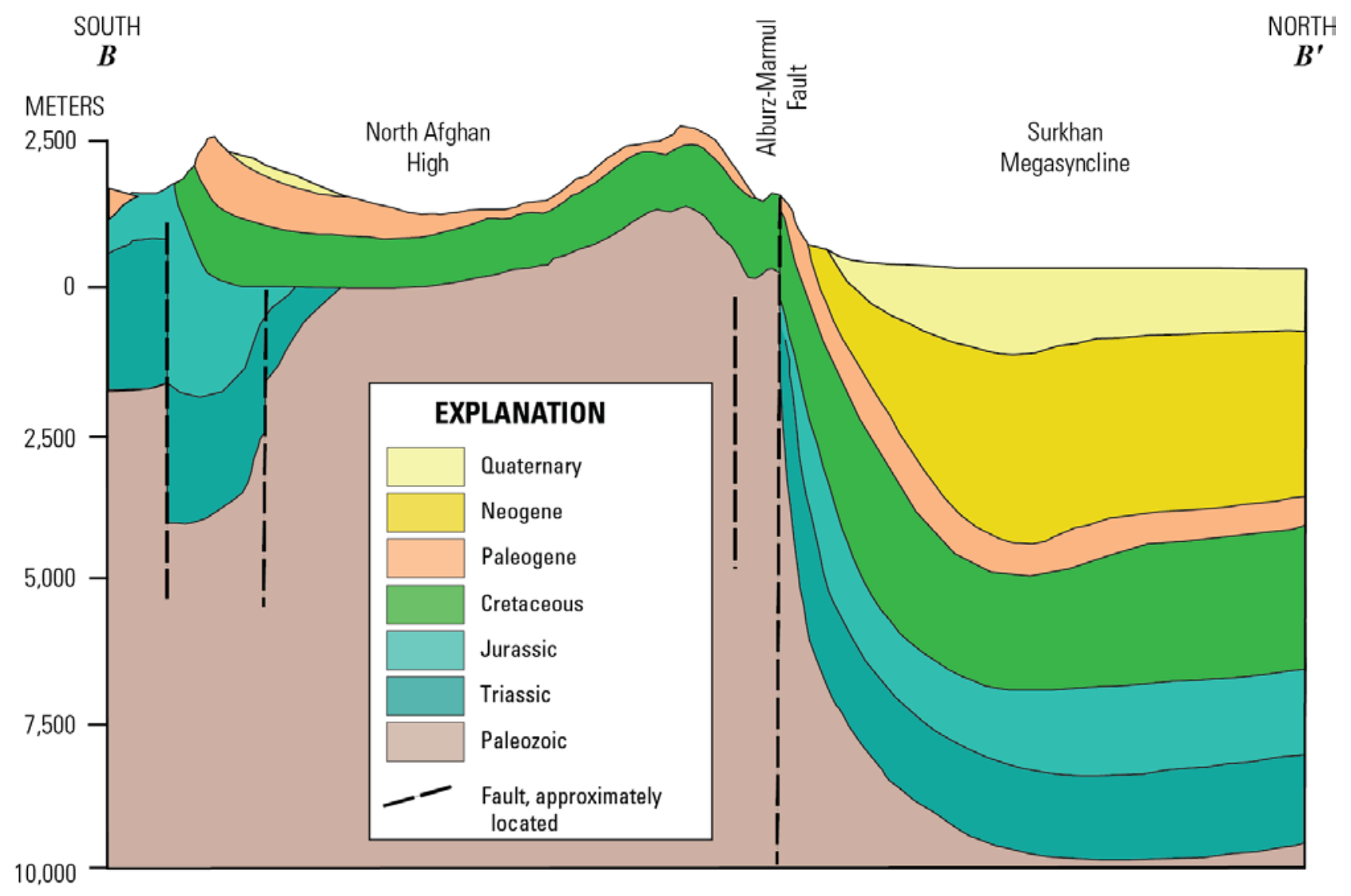

Figure 16. Geologic cross section from the northern part of the Afghan High to the Amu Darya River, Afghanistan (fig. 28, Klett and others, 2006). Units have been generalized by age. Readers should note impact of faults on sediment orientation and thickness. 


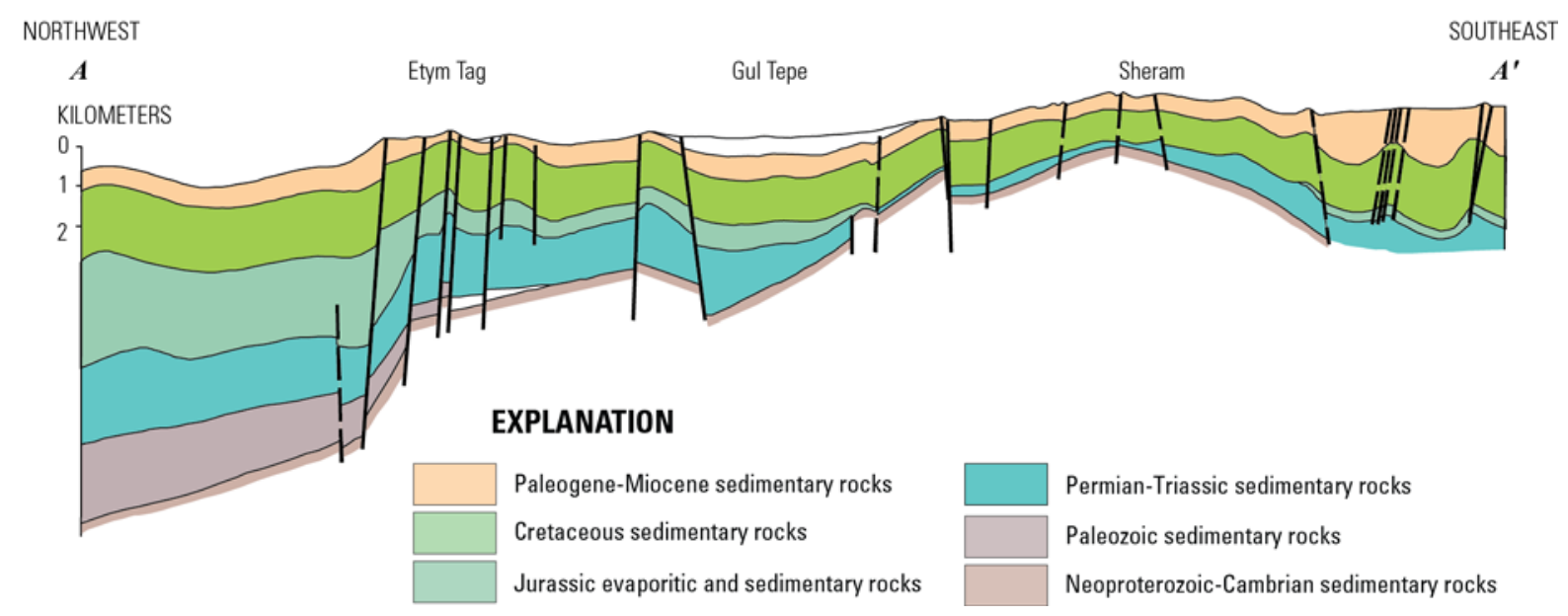

Figure 17. Geologic cross section from Andkhoy step to the North Afghan High (fig. 21; Klett and others, 2006). 


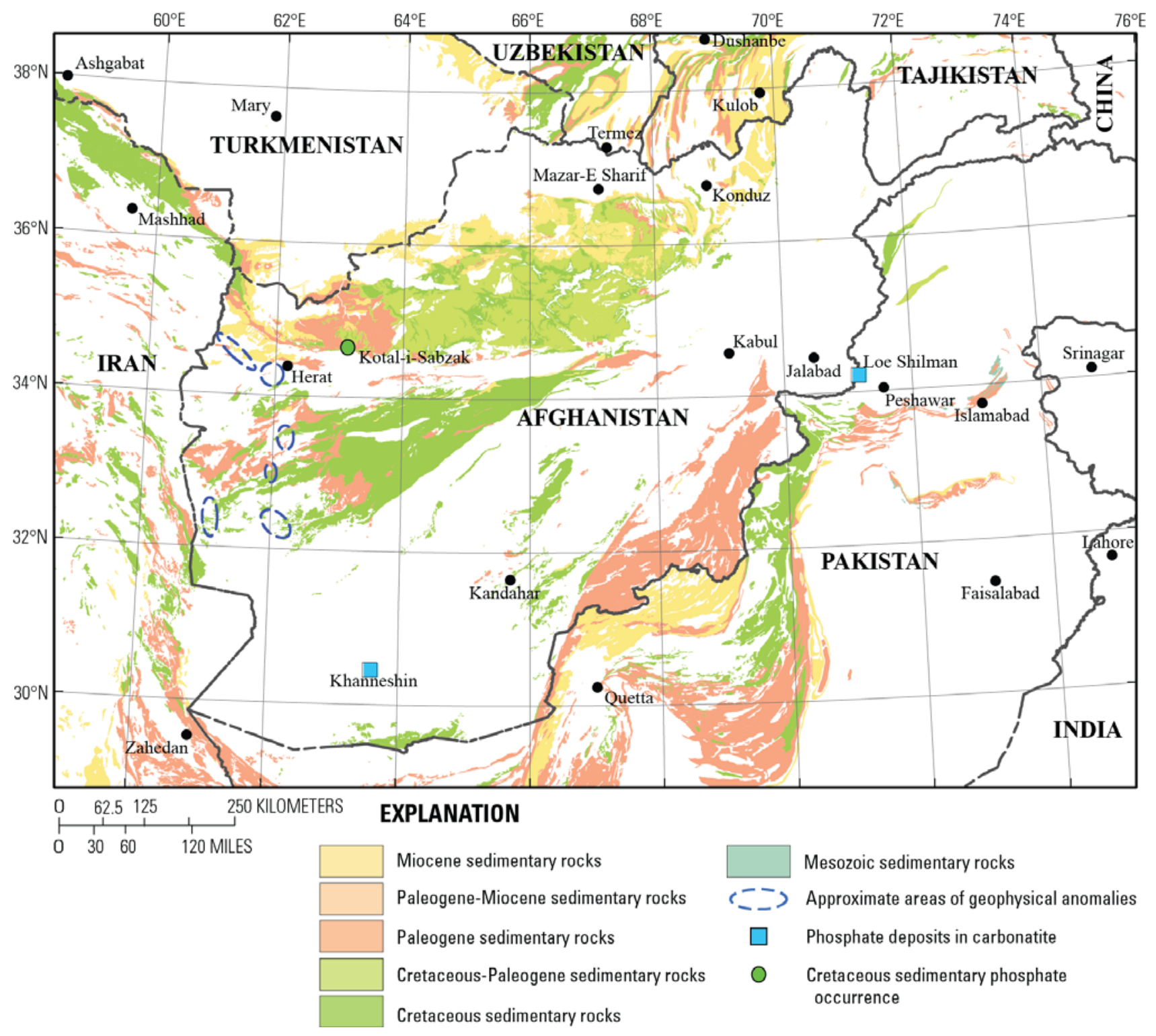

Figure 18. Geophysical anomalies that might indicate the presence of phosphate in the near surface relative to the Kotal-i-Sabzak occurrence in Afghanistan. 


\title{
Afghan Phosphate Geophysics Report
}

\author{
By Jeff Wynn
}

Magnetic, satellite (GRACE) gravity, and radiometric data were acquired for western Afghanistan and compared against each other. The objective was to help isolate phosphate sources in the west Afghanistan region where older Russian radiometric data were available. Because phosphate correlates well with uranium in other parts of the ancient Tethyan Sea (Wynn, 1993, 1996; see figs. 19 and 20), the emphasis in this report is primarily on uranium.

Borehole logging and chemical analysis were carried out on a large suite of boreholes in the alJalamid phosphate region of northern Saudi Arabia (Wynn, 1993; 1996). This research shows a remarkable correlation between phosphate content in boreholes and wireline gamma-ray counts, sampled on a $25-\mathrm{cm}$ interval. However, this correlation only holds closely below the near-surface weathered zone. Within that weathered zone, the phosphate was almost totally depleted, whereas the uranium content was generally reduced only by one half to two-thirds. This raises the question of how to identify the weathered zone. Our experience shows that a caliper log run along with a gamma-ray $\log$ can detect where the weathered layer remains, and its approximate thickness, because the weathered material is highly friable, and thus partially destroyed by the drilling process (fig. 20).

The very coarse-scale regional gravity data for western Afghanistan, as measured by the GRACE (Gravity Recovery and Climate Experiment; http://www.csr.utexas.edu/grace/) satellite system, is shown in figure 21 . Because of the low resolution of these data, it reflects only deep crustal density differences. This map likely has little correlation with post-Proterozoic phosphate deposition beyond indicating differing crustal masses.

The available magnetic data, acquired through the Geosoft DAP system from public-domain data, is shown in figure 22 (MacLeod and others, 2003). Data like these are often concatenated from several different data sets, each with different acquisition parameters, and thus there may be spline artifacts at the boundaries. This image can be viewed as a pseudo-geology map of western Afghanistan, with different distinct apparent sedimentary units distinguished by their differing magnetite content. Figure 23 shows these same magnetic data after a low-pass filter has been applied. The resulting image lacks the fine detail (including noise) to better reveal underlying rock units and structures. This version is thus more useful in identifying major geologic features.

The airborne-sensed potassium content (in percent) of a part of western Afghanistan is shown in figure 24 (data from Peters and others, 2007). It is important to remember that the airborne sensor is registering potassium only for the top few centimeters of the land surface. Using these data, the region is easily divisible by a band of high potassium, likely felsic rock, in the middle of two zones of otherwise generally low potassium content. Potassium feldspar alteration (for example, due to hydrothermal cells associated with a magmatic intrusion) can also be coincident with a demagnetization halo (very low magnetic susceptibility). Together these provide an important guide to a nonfuel mineral deposition and concentration process.

The thorium content (in ppm) over western Afghanistan is shown in figure 25 (data from Peters and others, 2007). As in the previous image, the region is easily divisible by a band of high thorium in the middle, bracketed by two zones of otherwise generally low thorium content. This image shows a roughly 80 percent correlation of thorium with potassium, which is unexpected, as thorium tends to be highly immobile, while potassium is chemically more easily transportable. This kind of correlation is even more remarkable in that most of the underlying rocks are S. One possible explanation is that 
potassium was mobilized later by weathering (conceivably by hydrothermal cells), and accumulated preferentially in rocks that also host thorium.

Uranium content (in ppm) is displayed over the topography of western Afghanistan in figure 26 (data from Peters and others, 2007). Because of experience elsewhere in Tethyan sedimentary deposits, we expect that uranium might correlate with (and thus act as a proxy for) phosphate in this region. Again, the region is easily divisible by a band (south-central part of the map) of high uranium, likely hosted in felsic rock, separating two zones of otherwise generally low uranium. There is a possible data artifact (if so, then likely due to a splicing error in data concatenation) appearing as a backward " 7 " in the east-central part of the image. This feature is suspect because it crosses topography (and gravity and magnetic domains). On the other hand, the same airborne acquisition system was used for the potassium and thorium channels, which do NOT have this possible artifact. In particular, the northtrending part of the anomalous band is not found in either the potassium or thorium images, and the east-trending component in the north correlates with a magnetic high and is almost certainly real. This east-trending, northernmost part lies over the raised terrain just north of, and trending parallel to, the Harirud River near Herat.

The GRACE gravity data are overlain by the uranium data in figure 27; the two datasets are superimposed here to search for possible correlations with deep crustal structure. There is a rough association of uranium with the gravity gradients (possible cratonic accretionary boundaries), but the gravity is arguably only "seeing" mid-crustal features.

An overlay of the uranium data onto the low-pass (desampled) magnetic data is shown in figure 28. There is some correlation between magnetic highs and the uranium on the southern third of the image; both are probably associated with shallow crustal structural features.

The uranium-potassium ratio data for western Afghanistan are shown in figure 29. This ratio is occasionally useful because uranium tends to be highly mobile, with potassium somewhat less so. Uranium is found in apatite, sphene, and zircon, whereas potassium is common in potash feldspars. When this ratio is high (red in the image) the implication is that the uranium has been mobilized and left its source rocks behind. It may thus no longer correlate with the phosphate content of the rocks.

The uranium-thorium ratio for western Afghanistan is shown in figure 30. This ratio is arguably more useful because uranium and thorium tend to originate in the same felsic rocks, but while uranium is highly mobile, thorium is not. Thorium normally migrates from its origin only when mechanically weathered, while uranium is chemically highly mobile in a wide range of temperatures and redox environments. Thus, a high value of this ratio (red in the image) again implies that uranium has moved substantially from its original depositional environment, and may not correlate well with phosphate. Except for the Khanneshin Carbonatite volcano, almost all uranium in western Afghanistan is sedimentary in origin. The uranium/thorium ratio should typically be close to 0.25 (Hoover and others, 1992).

The radioelement ternary diagram (Broome and others, 1987) shown in figure 31 provides colors keyed to one of three radioelements all on the same image; in this case uranium (red), thorium (blue), and potassium (yellow). In this image, black indicates (relatively) low radioactivity - typically found over mafic rocks and water - while white indicates (relatively) higher radioactivity, typically associated with felsic igneous rocks and their sedimentary derivatives. Again, it is important to keep in mind that airborne radioelement surveys are sensing only the top few centimeters of exposed land surface. Nevertheless, this may be the most useful map for phosphate exploration, as it suggests that sedimentary phosphate may be weathering out of six areas (yellow ellipses), into at least three regional drainages. Topography is represented by thin and medium green lines to be visible against the often black backdrop. Roads are thin yellow lines, and the country frontiers are shown as a thick black line. 


\section{Additional Work}

Beside the Khanneshin Carbonatite (located south of the maps here) sedimentary rocks of Tethyan Sea origin are likely the main source of phosphate in Afghanistan, as they are in neighboring Iran. The ternary radiometric diagram (fig. 31) above suggests two possible source areas of sedimentary uranium - and thus phosphate. Laboratory analysis and field experience in northern Saudi Arabia (figs. 19 and 20) suggest that phosphate content correlates closely with uranium in gamma-ray logs, at least below the weathering zone. The weathering zone can efficiently be mapped using a caliper log. If the Afghan Geological Survey invested in a shallow drilling program and a portable well-logging system, these together could be used to efficiently follow-up sedimentary phosphate content implied by remote sensing (airborne radiometric and magnetic) systems.

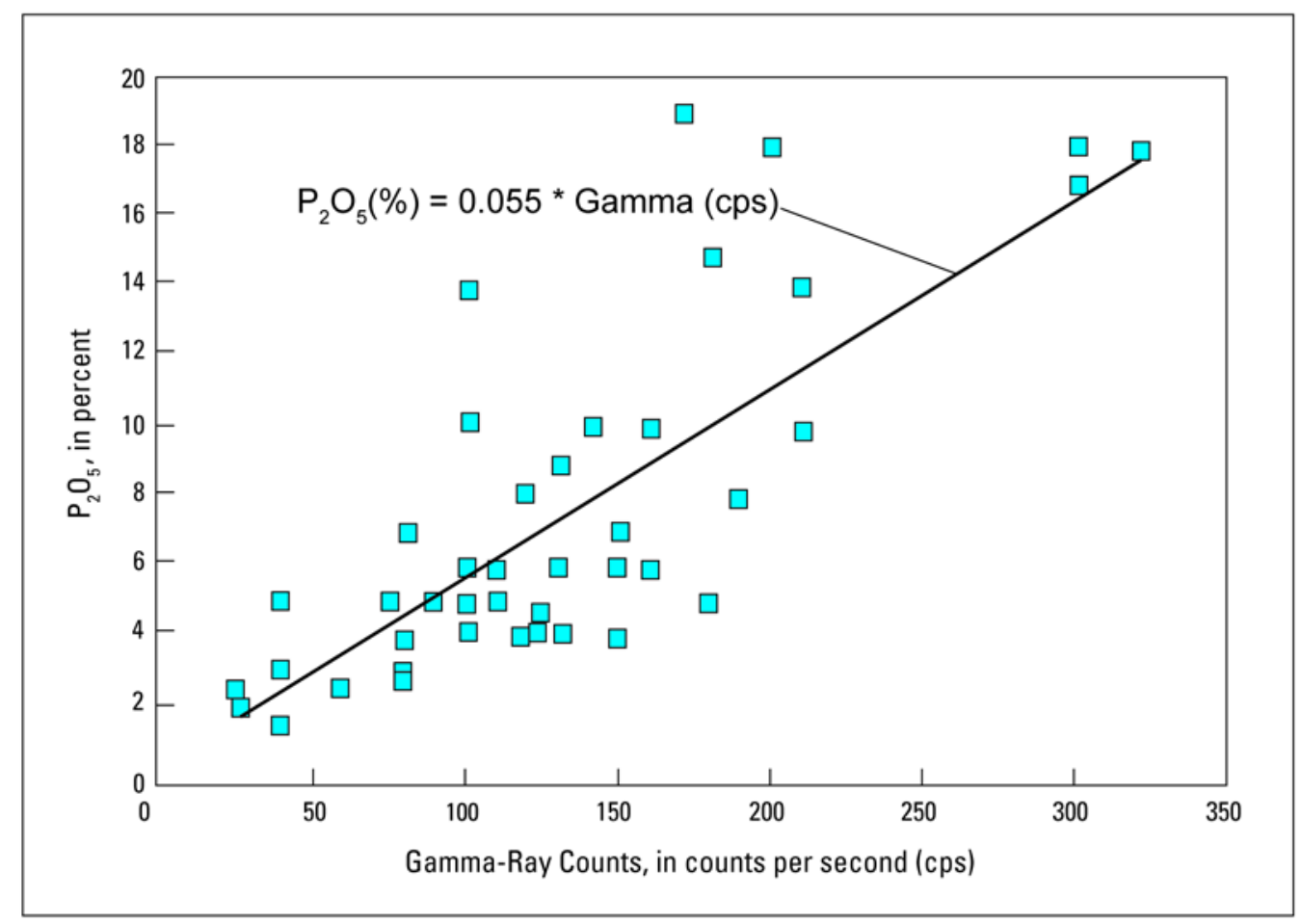

Figure 19. Correlation of uranium and phosphate contents in sediments of the paleo-Tethyan Sea. 


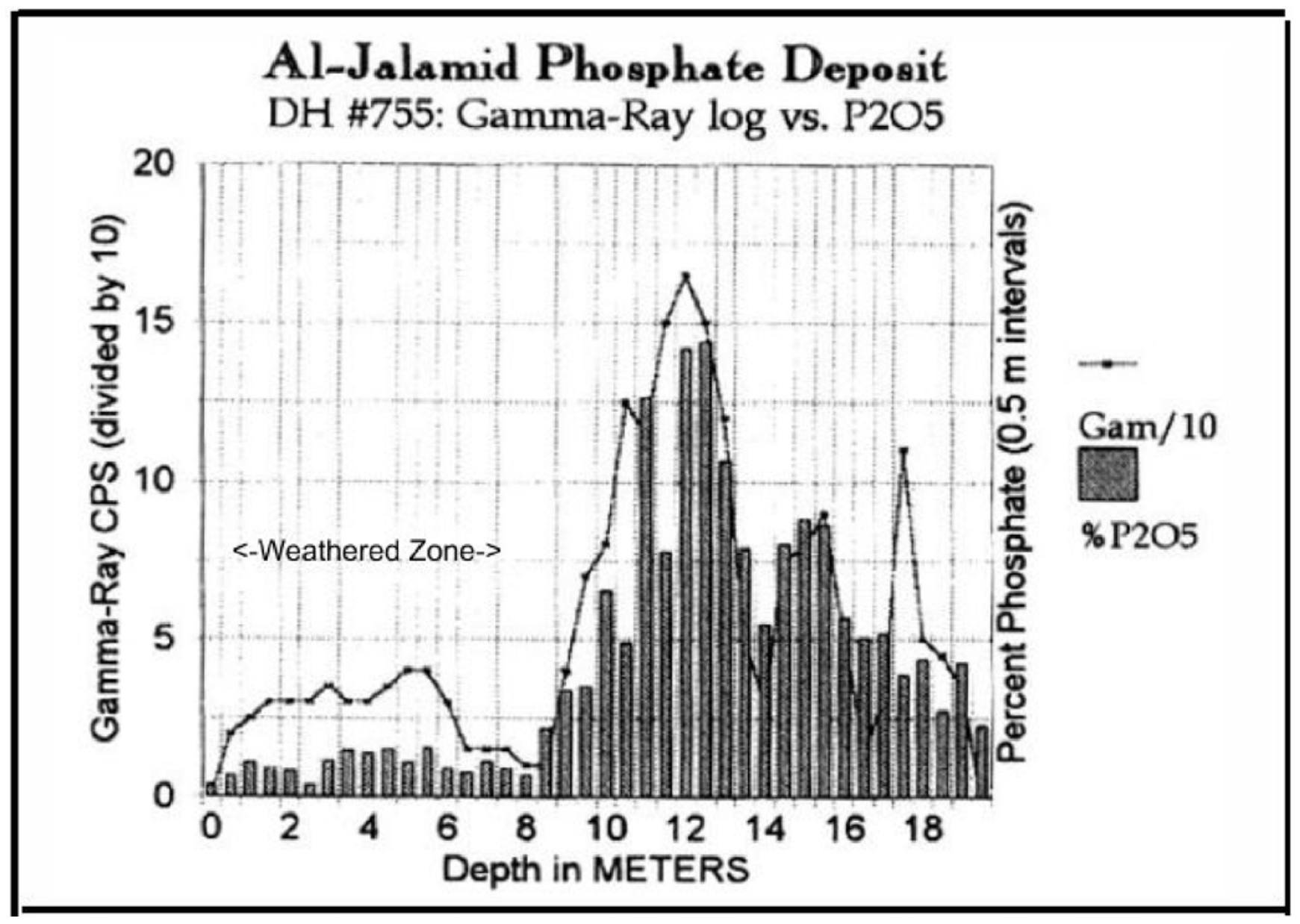

Figure 20. Gamma ray log and percent $\mathrm{P}_{2} \mathrm{O}_{5}$ versus depth for the Al Jalamid deposit, Saudi Arabia. 


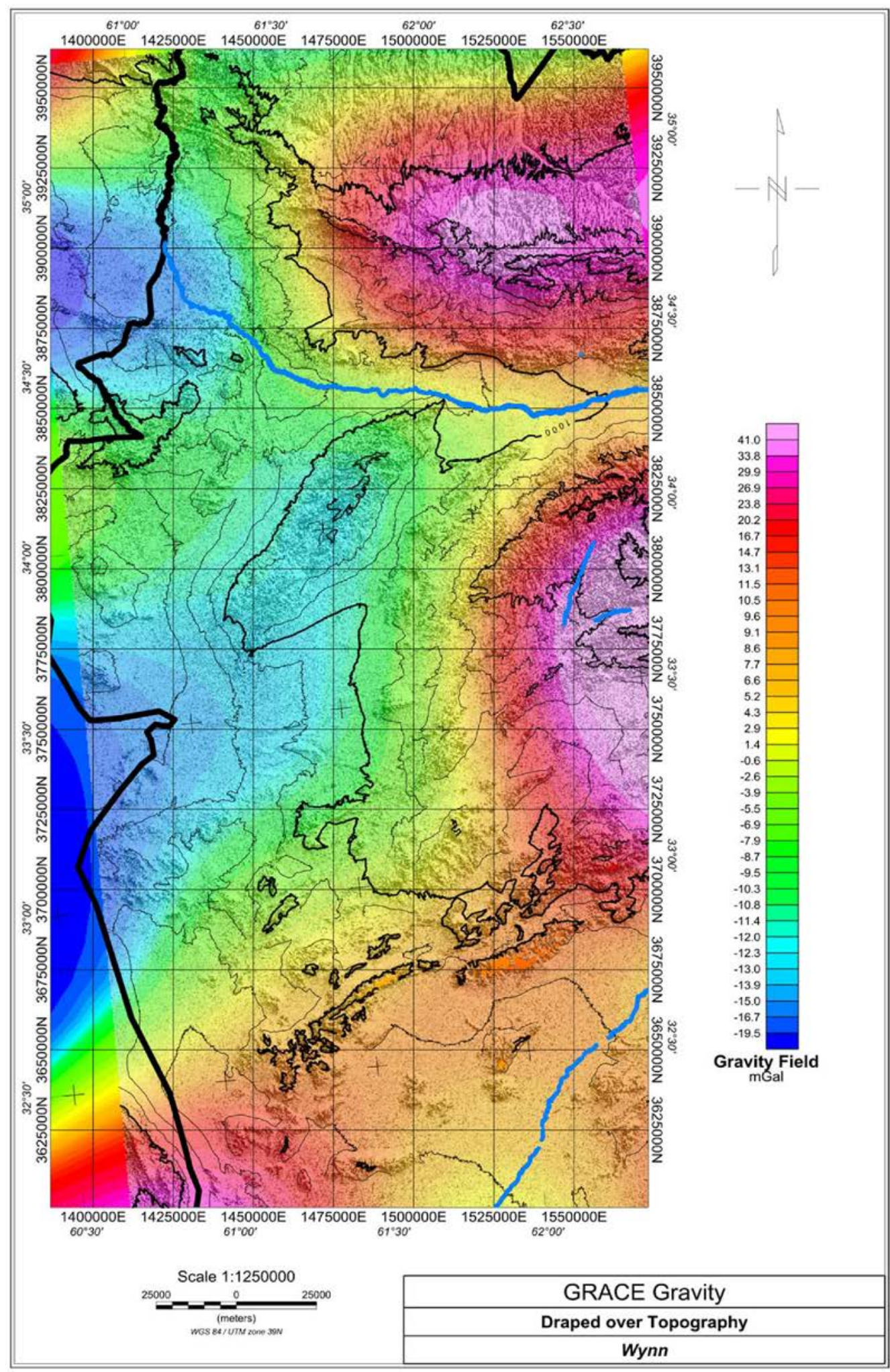

Figure 21. Gravity Recovery and Climate Experiment (GRACE) gravity data overlaid on topography for a part of western Afghanistan. The Harirud River in the north and the Farah River in the south are shown as thick blue lines. 


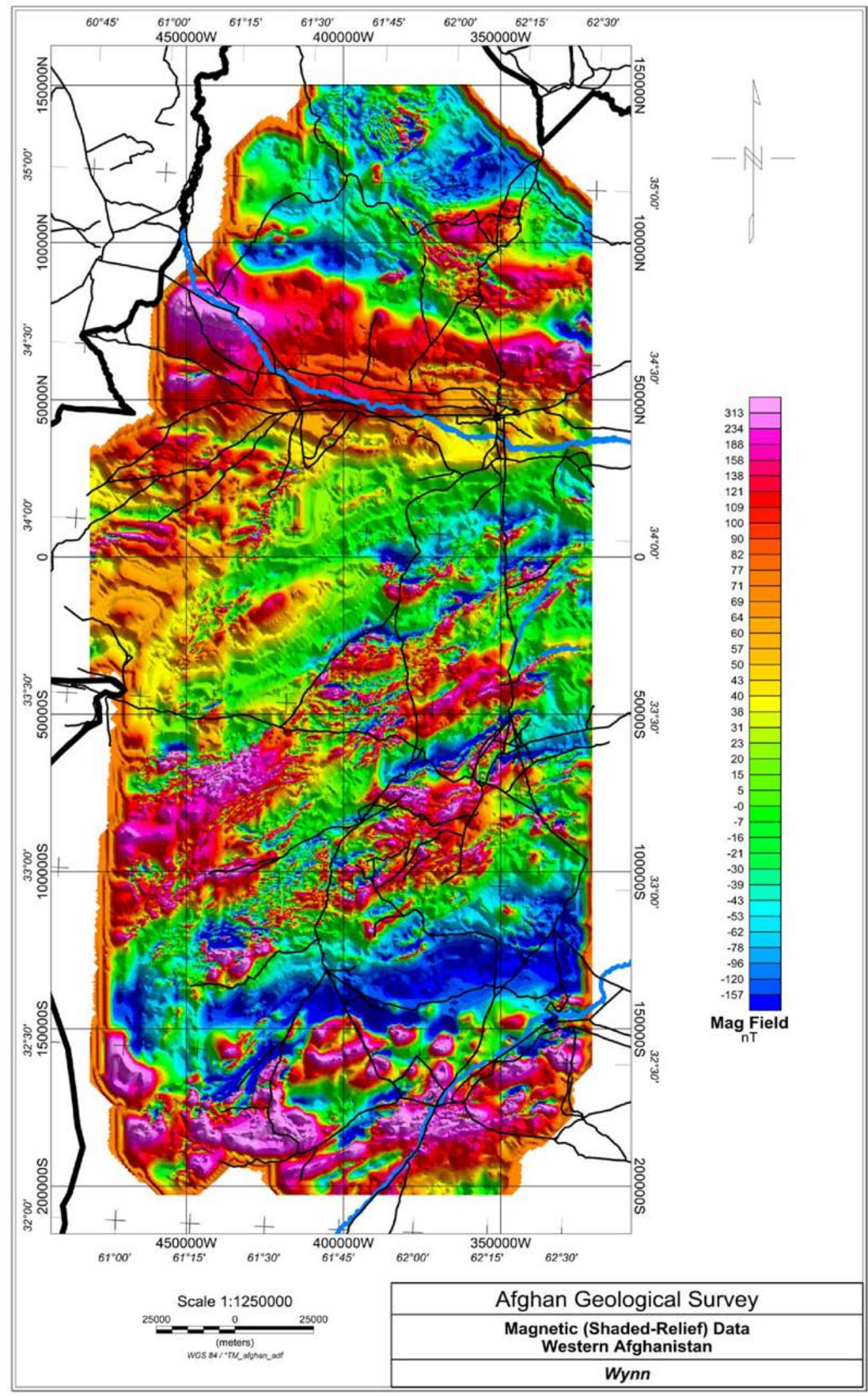

Figure 22. Magnetic (shaded-relief) data for a part of western Afghanistan. 


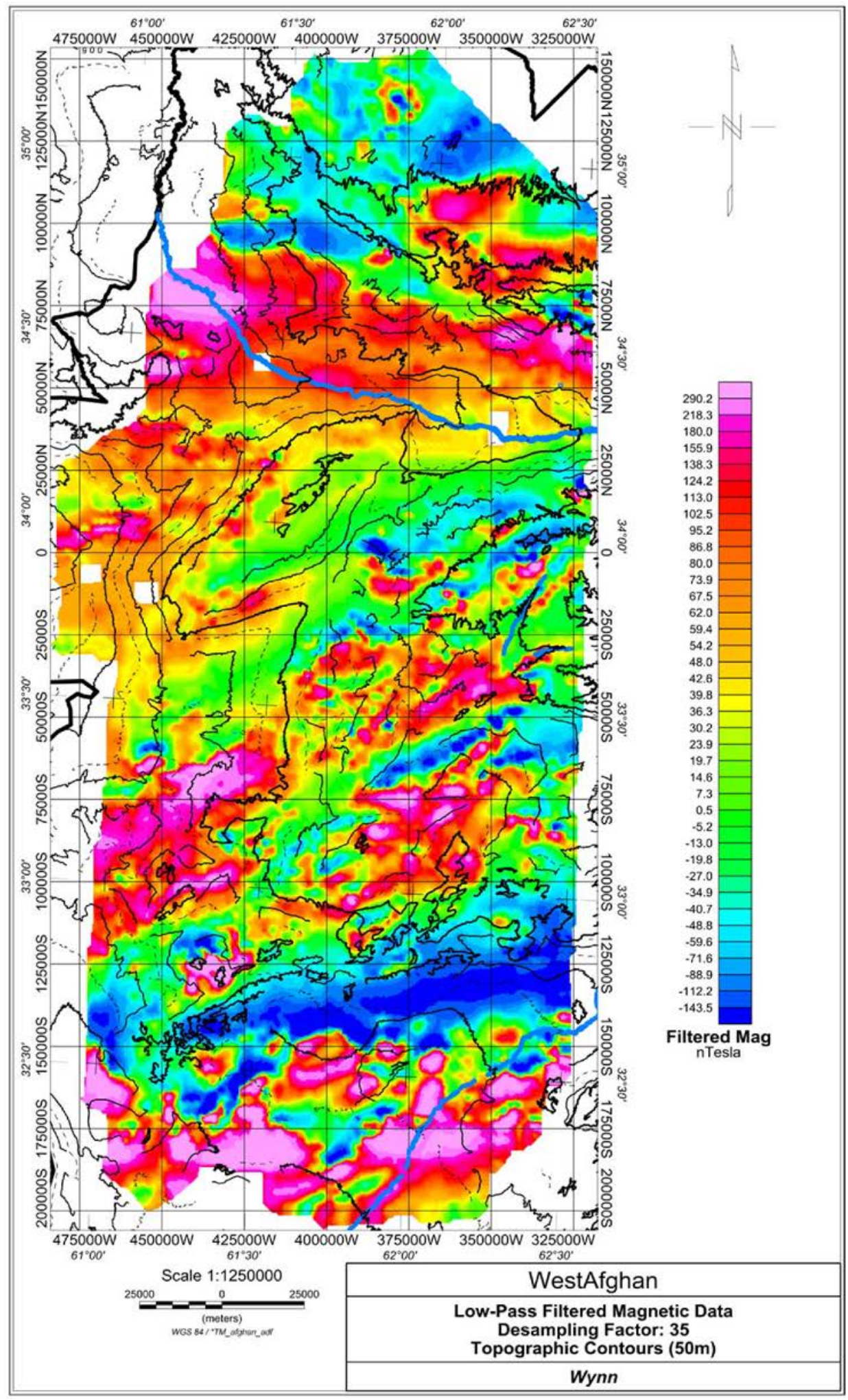

Figure 23. Low-pass filtered magnetic data overlaid on topographic contours in part of western Afghanistan. Topography in this map is shown as thin and medium black contours, while regional-scale drainages are shown as thick blue lines. The country frontiers are shown as thick black lines. 


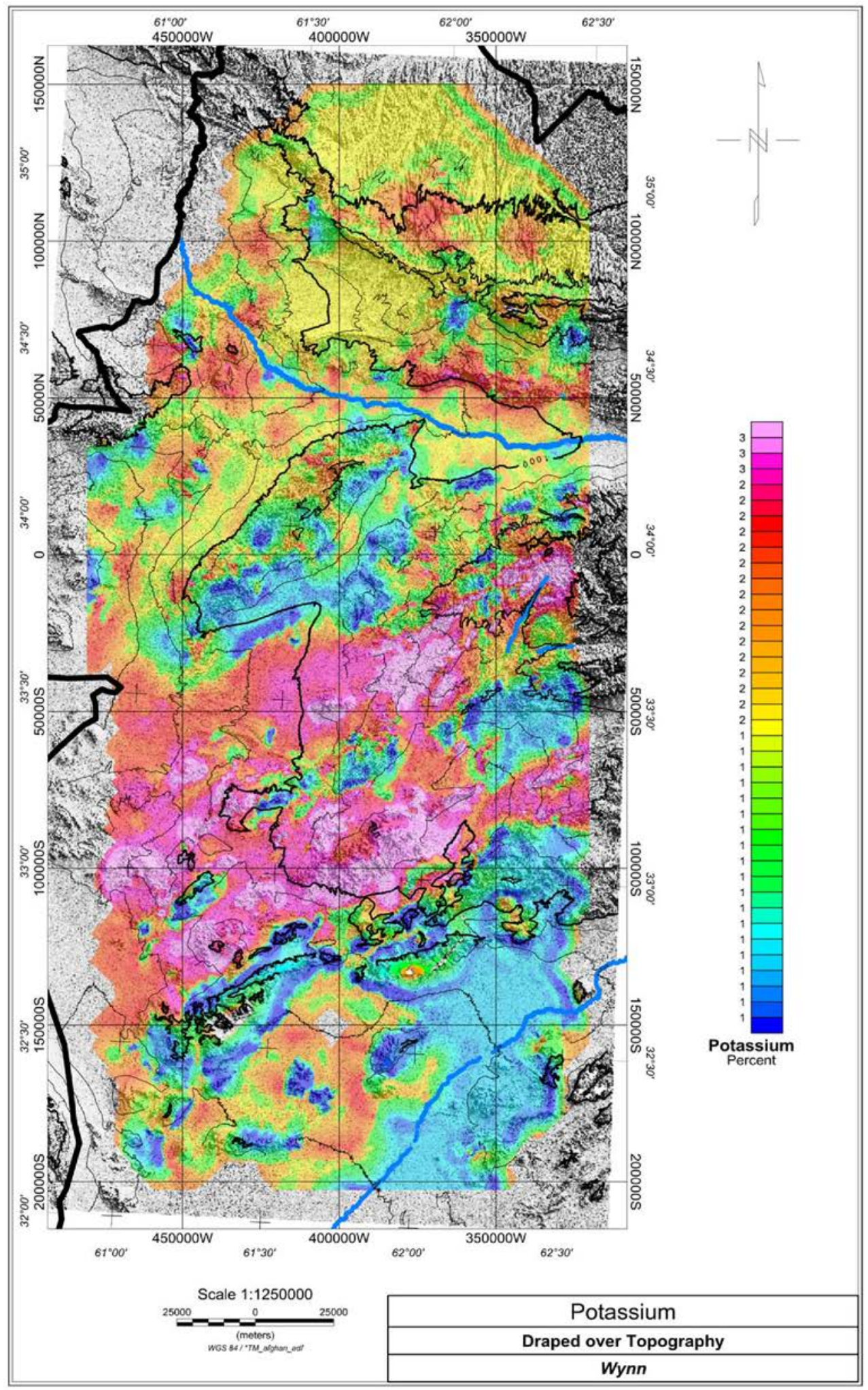

Figure 24. Airborne-sensed potassium data (in percent) overlaid on topography. Topography in this map is shown as thin and medium black contours, while regional-scale drainages are shown as thick blue lines. The country frontiers are shown as thick black lines. 


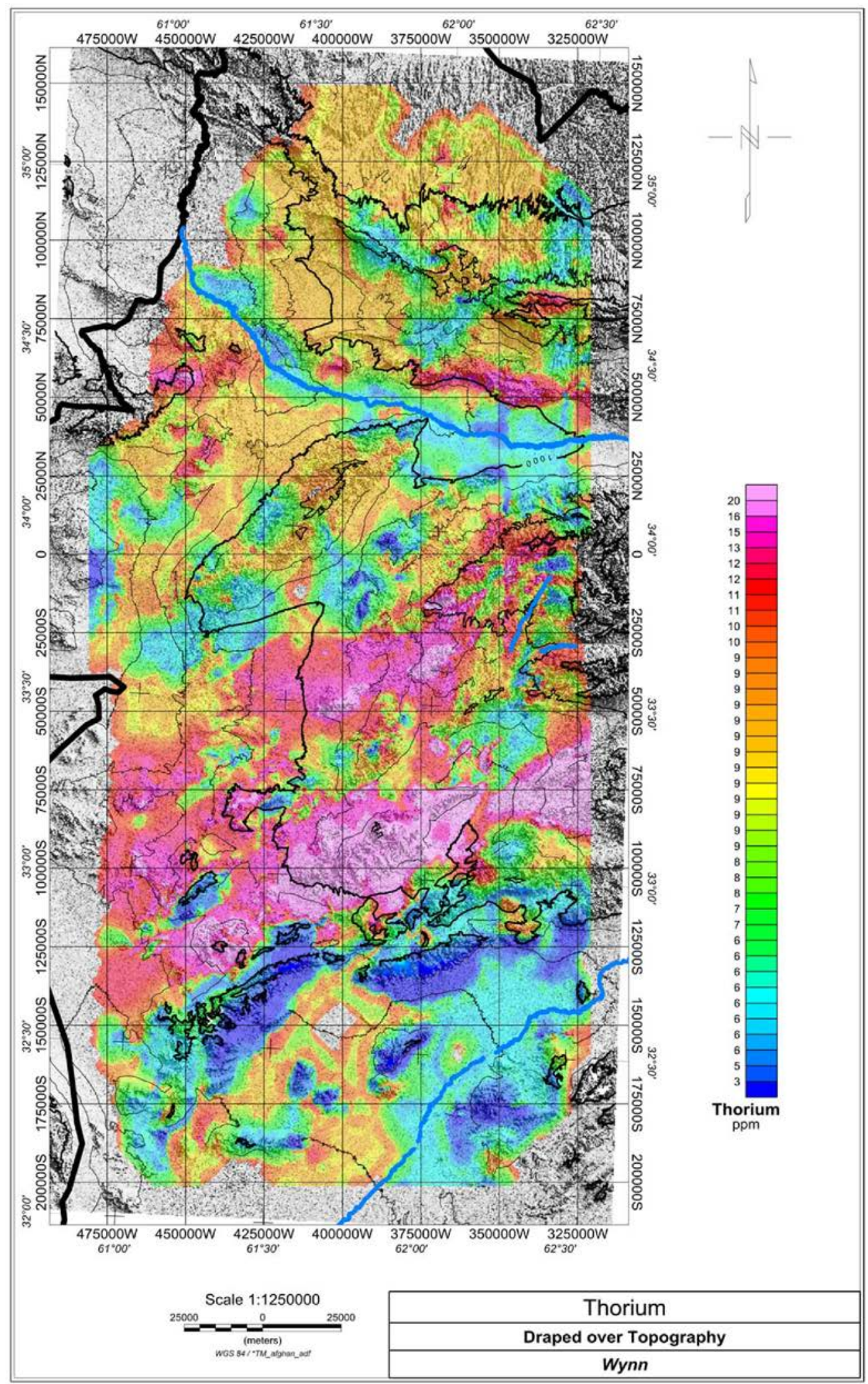

Figure 25. Airborne-sensed thorium data (in ppm) draped on topography. Topography is shown as thin black contours, regional-scale drainages are shown in blue. Country outline are shown as thick black lines. 


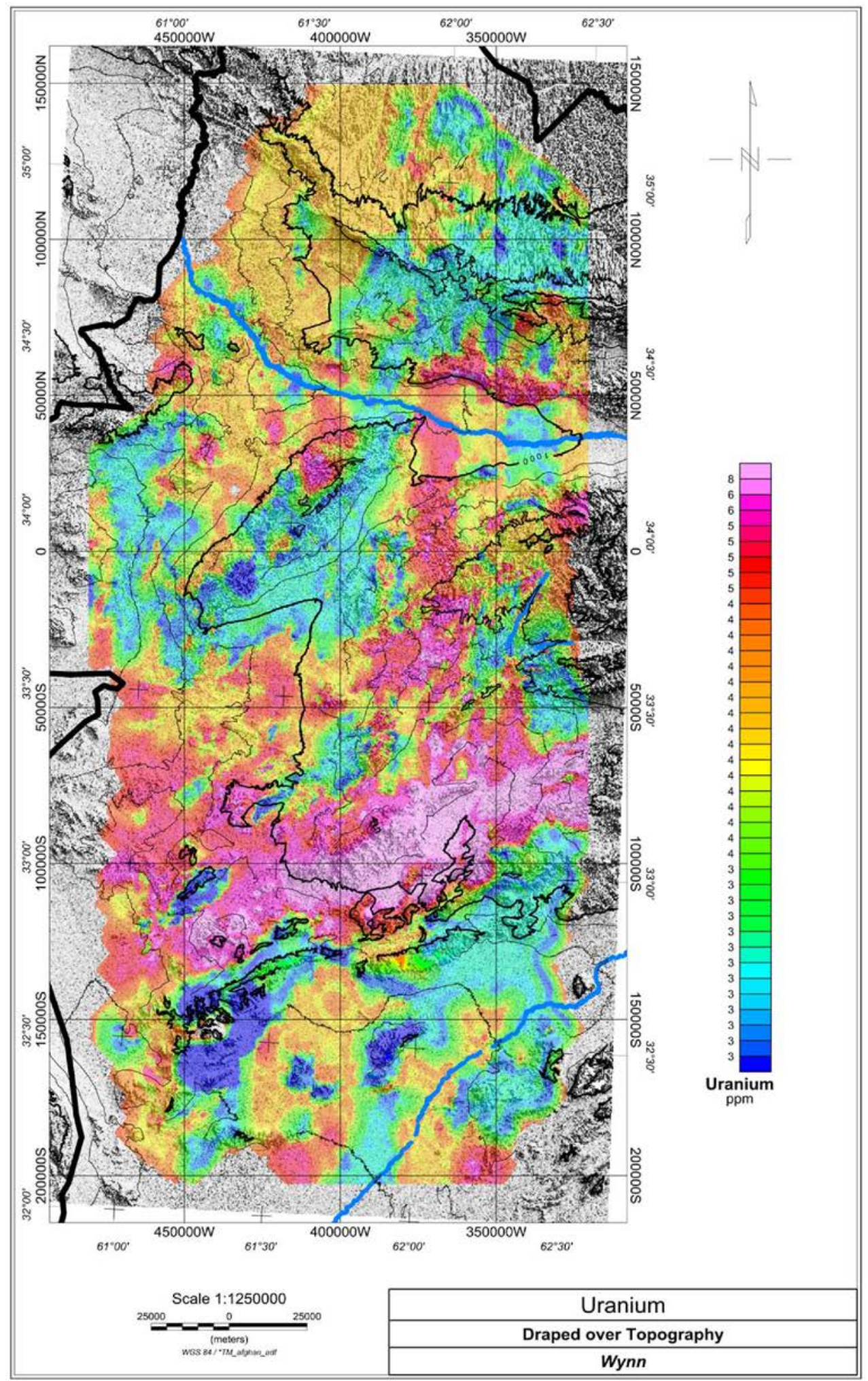

Figure 26. Airborne-sensed uranium data (in ppm) draped on topography. Topography is shown in thin and medium black contours in this image, while regional-scale drainages are shown as thick blue lines. The country frontiers are shown as thick black lines. 


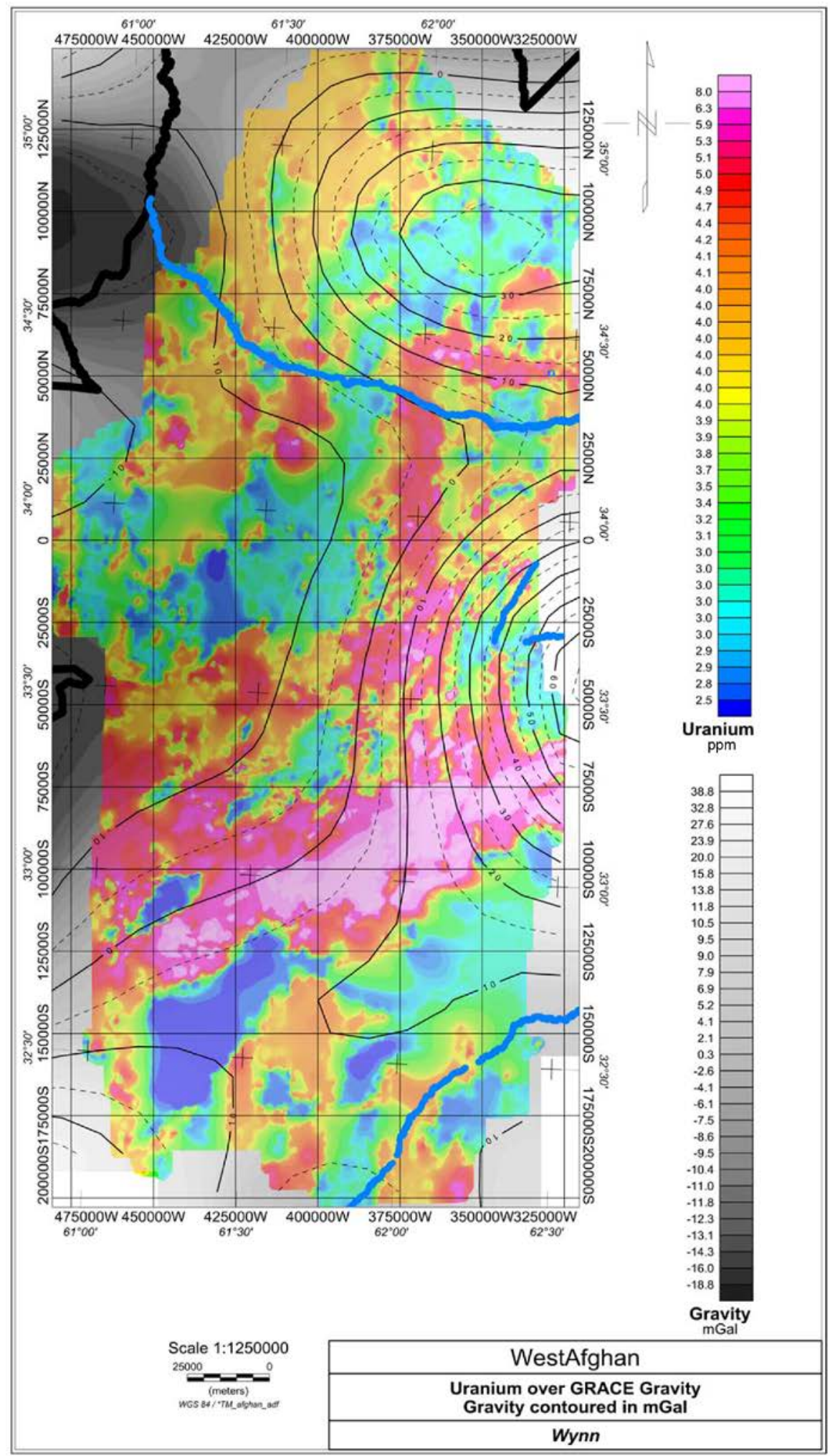

Figure 27. Airborne-sensed uranium data (in ppm) overlaid on GRACE gravity data (in $\mathrm{mGal}$ ). Thin black contours here are GRACE gravity data in milligals, while the large rivers are shown as thick blue lines. The country frontiers are shown as thick black lines. 


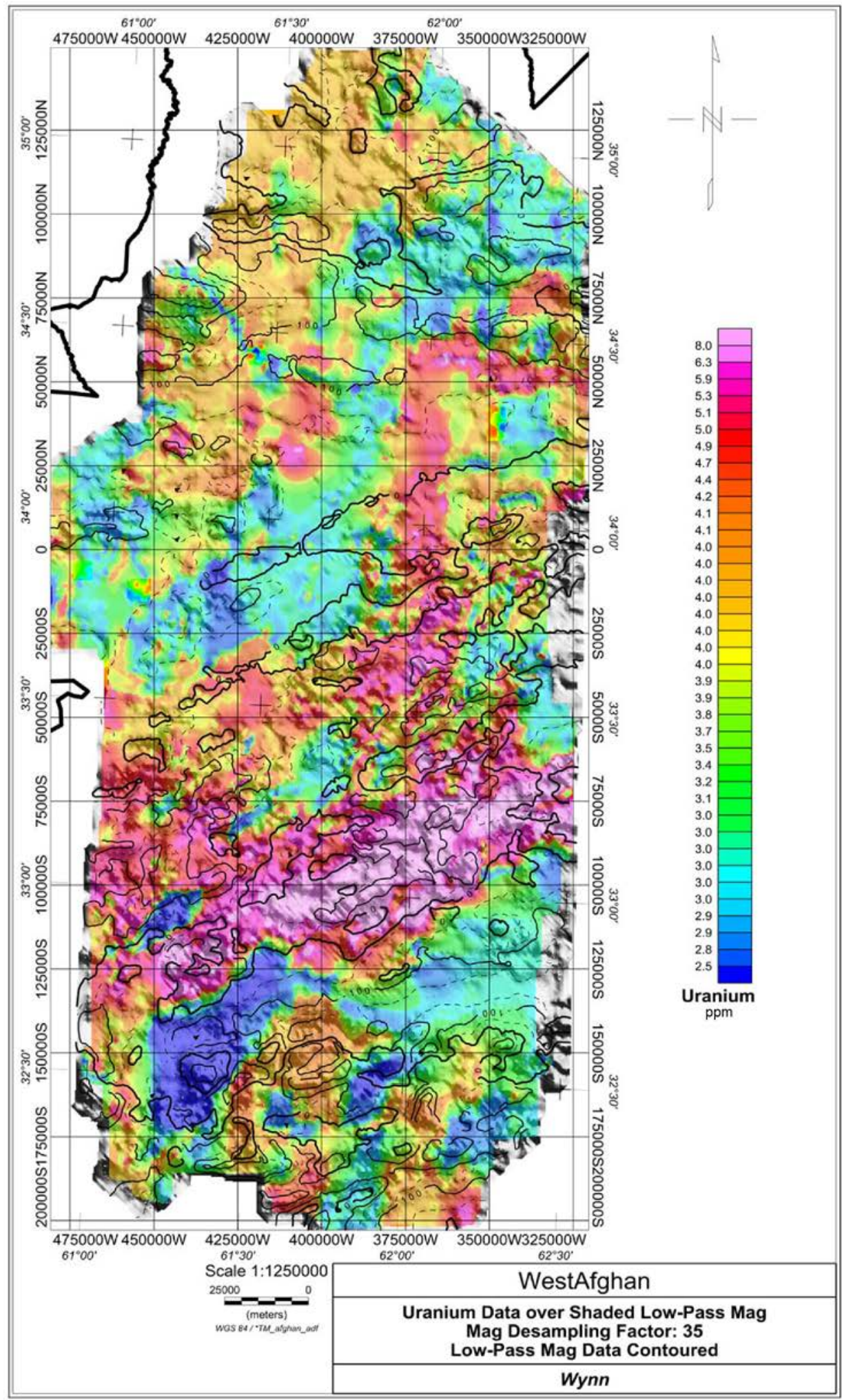

Figure 28. Airborne-sensed uranium data (in ppm) overlaid on shaded low-pass magnetics. Magnetic data here are thin black contours, and country frontiers are thick black lines. 


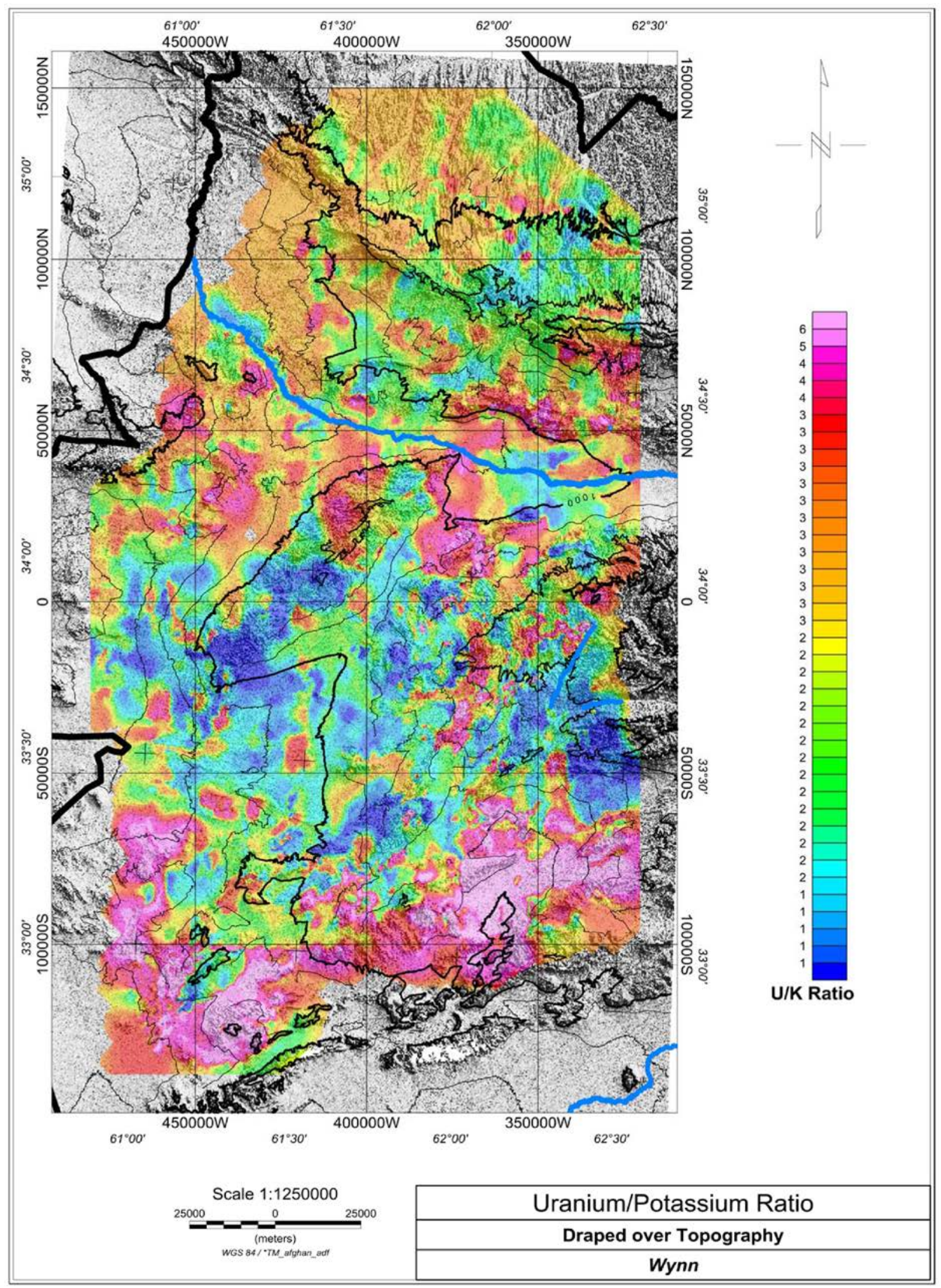

Figure 29. Uranium/potassium ratio data draped on shaded topography. 


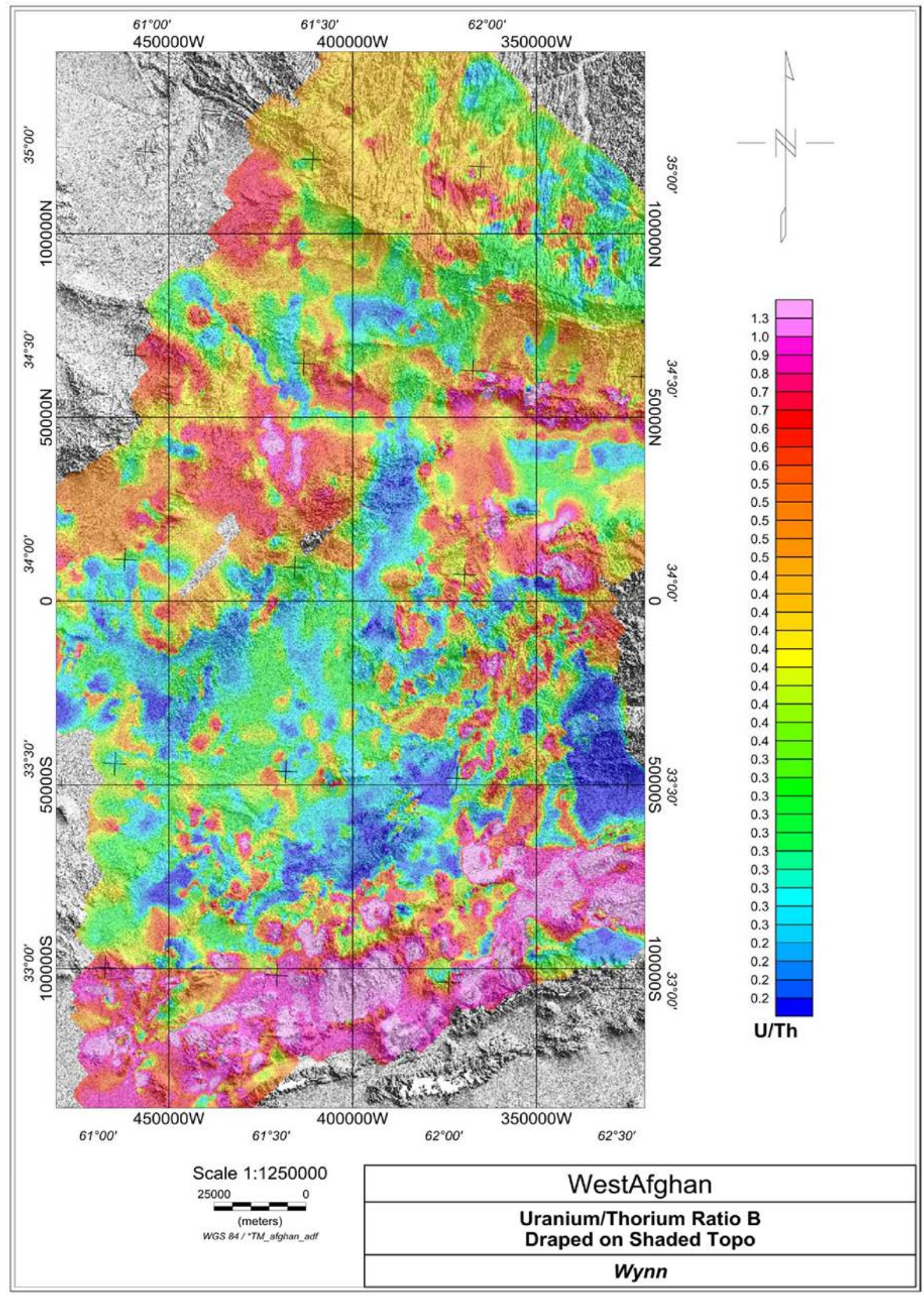

Figure 30. Uranium/thorium ratio data draped on shaded topography. 


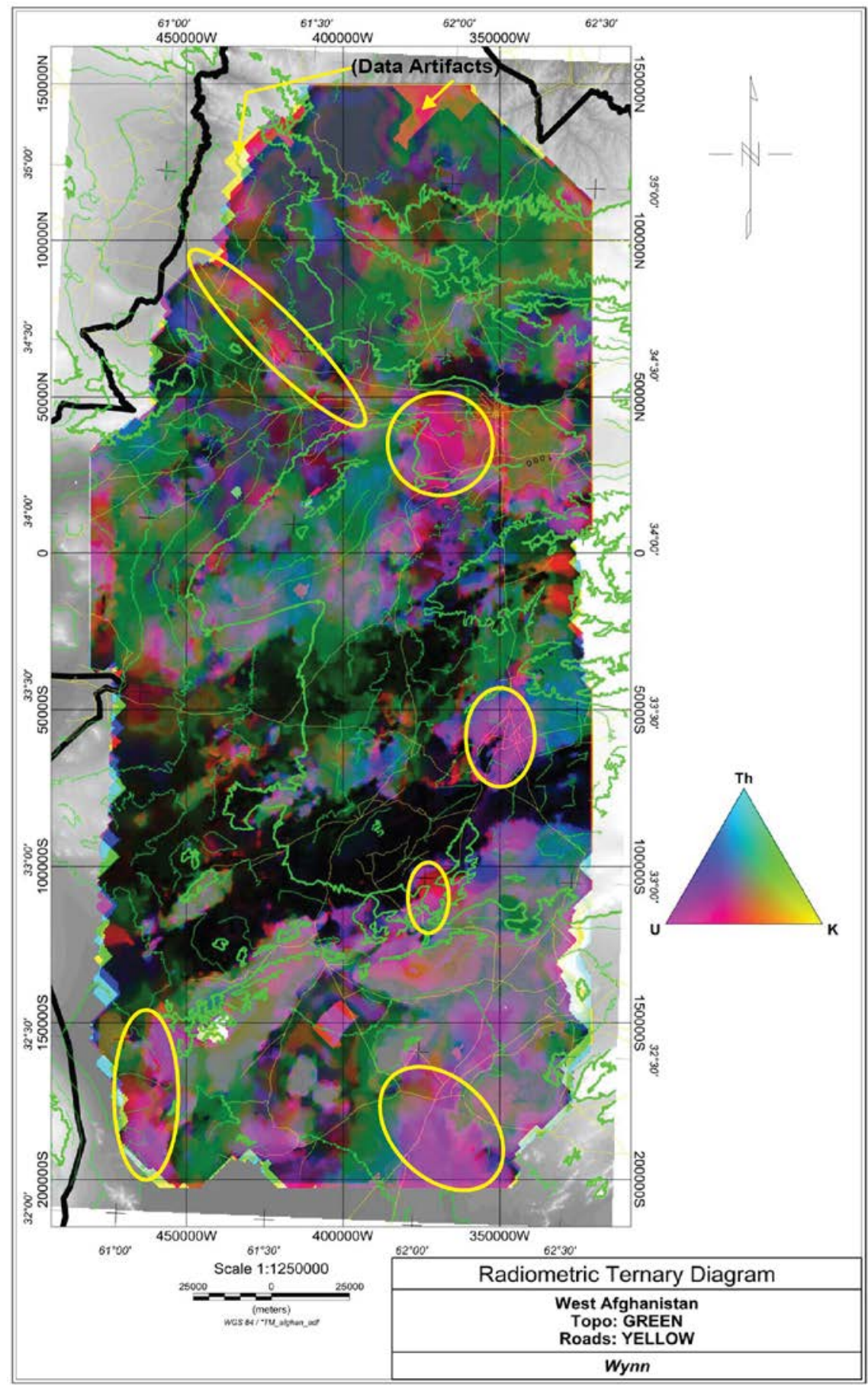

Figure 31. A U-Th-K radioelement ternary diagram for west Afghanistan, designed to show each of the three radioelements on the same image; in this case uranium (red), thorium (blue), and potassium (yellow). Topography (thin and medium green lines), roads (thin yellow lines), and the country border (thick black line). The six yellow ellipses represent areas where uranium is probably weathering out of nearby (up-drainage) sediments. An area with some of the larger data artifacts is identified with a yellow arrow. Topography is represented by thin and medium green lines to be visible against the often black backdrop. Roads are thin yellow lines, and the country frontiers are shown as a thick black line. 


\section{Acknowledgments}

The authors would like to thank Stephen G. Peters for his leadership of the Afghanistan minerals studies and, in particular, for his support of the phosphate investigation. In addition, we are grateful to Jack Medlin and Stephen G. Peters for their timely review of the manuscript, and to Nora Shew for reviewing the GIS.

\section{References Cited}

Abdullah, Sh., and Chmyriov, V.M., eds., 1977, Map of mineral resources of Afghanistan: Kabul, Afghanistan, Ministry of Mines and Industries, Department of Geological and Mineral Survey, V/O Technoexport USSR., scale 1:500,000.

Abdullah, Sh., Chmyriov, V.M., and Dronov, V.I., eds., 1980, Geology and mineral resources of Afghanistan, volumes 1 and 2: Republished in 2008 by British Geological Survey as Occasional Publication 15, 2 vols., 488 p.

Afghanistan Ministry of Mines and Petroleum, 2014, Phosphate of Afghanistan: Afghanistan Ministry of Mines and Petroleum Minerals in Afghanistan, 4 p.

Akhmetiev, M.A., Zaporozhets, N.I., Benyamovskiy, V.N., Aleksandrova, G.N., Iakovleva, A.I., and Oreshkina, T.V., 2012, The Paleogene history of the Western Siberian Seaway-a connection of the Peri-Tethys to the Arctic Ocean: Austrian Journal of Earth Sciences, v. 105, no. 1, p. 50-67.

Ali, S.T., 1974, Phosphate deposits of Pakistan, in Symposium on utilization of natural resources in Pakistan for self reliance: Lahore, Pakistan, West Pakistan Engineering Congress, p. 83-104.

Alkhazov, V.Yu., Atakishiyev, Z.M., and Azimi, N.A., 1978, Geology and mineral resources of the early Quaternary Khanneshin carbonatite volcano (southern Afghanistan): International Geology Review, v. 20, no. 3, p. 281-285.

Appleton, J.D., and Notholt, A.J.G., 2002, Local phosphate resources for sustainable development in India, Nepal, Pakistan and southeast Asia: British Geological Survey Report CR/02/123, 79 p.

Asrarullah, 1980, Phosphate, potash and natural gas occurrences in Pakistan, in Lee, A.I.N., ed., Fertilizer mineral occurrences in the Asia-Pacific region: Honolulu, Hawaii, East-West Resource Systems Institute, p. 66-77.

Bahrami, Mohammad, 2009, Microfacies and sedimentary environments of Gurpi and Pabdeh Formations in southwest of Iran: American Journal of Applied Sciences, v. 6, no. 7, p. 1295-1300.

Belenky, G.A., Ibragimov, R.N., and Morozov, S.D., 1972, Litologo-fatsial'naya Haraktyeristika polyeotsyenovih i zhotsyenovih otlozhyeniy yoogo-zapadnih otrogov gissarskogo hryebta [Lithology and facies of Paleocene and Eocene deposits in the southwestern Gissar Range]: Voprosy stratigrafii i paleogeografii, v. 408, p. 52-65.

Benninger, L.M., and Hein, J.R., 2000, Diagenetic evolution of seamount phosphorous, in Glenn, C.R., Prévot-Lucas, L., and Lucas, J., eds., Marine authigenesis-From global to microbial: Tulsa, Okla., Society of Economic Mineralogists and Paleontologists Special Publication 66, p. 245-256.

Bikbaeva, B.I., 1994, [Geological map of the Russian Federation, new series, sheet K-(39),(40) Krasnovodsk, Map of the pre-Quaternary rocks]: Leningrad, Russian Ministry of Geology, Karpinsky Russian Geological Research Institute (VSEGEI), scale 1:1,000,000. [In Russian.] Bilqees, R., 1995, Petrological studies of some phosphorite deposits of Hazara, Pakistan and their economic importance: Peshawar, Pakistan, University of Peshawar, National Centre of Excellence in Geology, M.S. thesis, 65 p. 
Broome, J., Carson, J.M., Grant, J.A., and Ford, K.L., 1987, A modified ternary radioelement mapping technique and its application to the south coast of Newfoundland: Geological Survey of Canada Paper 87-14, 1 sheet, scale 1:500,000 with text.

Cathcart, J.B., and Schmidt, D.L., 1977, Middle Paleozoic sedimentary phosphate in the Pensacola Mountains, Antarctica: U.S. Geological Survey Professional Paper 456-E, 18 p.

Cook, P.J., 1976, Sedimentary phosphate deposits, in Wolf, K.H., ed., Handbook of strata-bound and stratiform ore deposits; II-Regional studies and specific deposits; Vol. 7- $\mathrm{Au}, \mathrm{U}, \mathrm{Fe}, \mathrm{Mn}, \mathrm{Hg}, \mathrm{Sb}$, W, and P deposits: Amsterdam, Elsevier, p. 505-535.

Cook, P.J., Banerjee, D.M., and Southgate, P.N., 1990, The phosphorus resources of Asia and Oceania, in Phosphorus requirements for sustainable agriculture in Asia and Oceania: International Rice Research Institute, p. 97-114.

Daliran, Farahnaz, 2002, Kiruna-type iron oxide-apatite ores and apatites of the Bafq district, Iran, with an emphasis on the REE geochemistry of their apatites, in Porter, T.M., eds., Hydrothermal iron oxide, copper-gold and related deposits - A global perspective, volume 2: Adelaide, PGC

Publishing, p. 303-320.

Dastanpour, Mohammad, 1996, The Devonian System in Iran-a review: Geological Magazine, v. 133, no. 2, p. 159-170.

Doebrich, J.L., and Wahl, R.R., comps., 2006, Geologic and mineral resource map of Afghanistan (ver. 2): U.S. Geological Survey Open-File Report 2006-1038, scale 1:850,000. [Also available at http://pubs.usgs.gov/of/2006/1038/.]

Economic and Social Commission for Asia and the Pacific (ESCAP), 1995, Geology and mineral resources of Afghanistan: New York, United Nations, Atlas of Mineral Resources of the ESCAP Region, v. 11, 85 p.

Eriomenko, G.K., and Chmyriov, V.M., 1975, A brief characteristic of the Khanneshin carbonatite paleovolcano: Kabul, Afghanistan, Department of Geological and Mineral Survey, not paginated.

Esfordi Phosphate, 2013, Geology-Mine: Esfordi Phosphate Industrial and Mineral Complex Web page, accessed December 21, 2013, at http://www.iran-phosphat.com/mining.php.

Ghavidel-Syooki, Mohammad, 1988, Palynostratigraphy and paleoecology of the Farghan Formation of southeastern Iran: East Lansing, Mich., Michigan State University, Department of Geology, Ph.D. dissertation, $279 \mathrm{p}$.

Gholizadeh, A., Ardalan, M., Tehrani, M.M., Hosseini, H.M., and Karimian, N., 2009, Solubility test in some phosphate rocks and their potential for direct application in soil: World Applied Sciences Journal, v. 6, no. 2, p. 182-190.

Ghorbani, Mansour, 2013, The economic geology of Iran-Mineral deposits and natural resources: New York, Springer, 569 p.

Ghorbani, M., Rostamnejad, A., and Valiani, Z., 2014, Microfacies, petrofacies and sedimentary environment of the Bahram Formation in Hutk section (northern Kerman), Iran: International Journal of Geology, Earth and Environmental Sciences, v. 4, no. 1, p. 68-84.

Hallam, A., and Maynard, J.B., 1987, The iron ores and associated sediments of the Chichali Formation (Oxfordian to Valanginian) of the Trans-Indus Salt Range, Pakistan: Journal of the Geological Society of London, v. 144, p. 107-114.

Hamdi, B., Brasier, M.D., and Jiang, Z., 1989, Earliest skeletal fossils from Precambrian-Cambrian boundary strata, Elburz Mountains, Iran: Geological Magazine, v. 126, no. 3, p. 283-289.

Hasan, M.T., 1986, Proterozoic and Cambrian phosphorites; Deposits-Hazara, Pakistan, in Cook, P.J., and Shergold, J.H., eds., Phosphate deposits of the world; Volume 1-Proterozoic and Cambrian phosphorites: Cambridge, Cambridge University Press, p. 190-201. 
Hasan, M.T., 1989, Cambrian phosphorite deposits of the Hazara Division, North West Frontier Province, Pakistan, in Notholt, A.J.G., Sheldon, R.P., and Davidson, D.F., eds., Phosphate deposits of the world; Volume 2-Phosphate rock resources: Cambridge, Cambridge University Press, $p$. 449-454.

Hasan, M.T., and Asrarullah, 1989, Phosphate (apatite) resources in the Loe Shilman C, Khyber Agency, North West Frontier Province, Pakistan, in Notholt, A.J.G., Sheldon, R.P., and Davidson, D.F., eds., Phosphate deposits of the world; Volume 2-Phosphate rock resources: Cambridge, Cambridge University Press, p. 455-457.

Hein, J.R., Yeh, H.-W., Gunn, S.H., Slitter, W.V., Benninger, L.M., and Wang, C.-H., 1993, Two major Cenozoic episodes of phosphogenesis recorded in equatorial Pacific seamount deposits: Paleoceanography, v. 8, no. 2, p. 293-311.

Hoover, D.B, W.D. Heran, and P.L. Hill, 1992, The geophysical expression of selected mineral deposit models: U.S. Geological Survey Open-File Report 92-557, 129 p. [Also available at http://pubs.usgs.gov/of/1992/ofr-92-0557/.]

Huber, H., comp., 1978, Geological map of Iran: National Iranian Oil Company, 6 sheets, scale $1: 1,000,000$.

Il'yashenko, V.Ya., 1967, Phosphorites of Paleogene sediments in the central part of Central Asia: Lithology and Mineral Resources, v. 1967, p. 713-723.

Ilyin, A.V., and Boiko, V.S., 1989, The Kisil Kum phosphorite deposits, Middle Asia, USSR, in Notholt, A.J.G., Sheldon, R.P., and Davidson, D.F., eds., Phosphate deposits of the world; Volume 2-Phosphate rock resources: Cambridge, Cambridge University Press, p. 507-509.

Iran Geological Survey, 2013a, Distribution of mineral deposits \& occurrences of phosphate: Tehran, Iran, Iran Geological Survey Web page, accessed November 23, 2013, at http://www.gsi.ir/Images/WEBMINE/p/table_p.htm.

Iran Geological Survey, 2013b, Mineral deposits database of Iran: Tehran, Iran, Iran Geological Survey National Geoscience Database, accessed March 29 and August 17, 2013, at http://www.ngdir.ir/MiningInfo/MiningInfo.asp.

Ishaque, M., and Ahmad, I., 1987, The potential of Hazara phosphates for phosphoric acid manufacture: Fertilizer Research, v. 14, no. 3, p. 257-263.

Jafari, S.M., Shemirani, A., and Hamdi, B., 2007, Microstratigraphy of the Late Ediacaran to the Ordovician in NW Iran (Takab area), in Vickers-Rich, Patricia, and Komarower, Patricia, eds., The rise and fall of the Ediacaran biota: Geological Society of London Special Publication 286, p. 433437.

Jami, Morteza, 2005, Geology, geochemistry and evolution of the Esfordi phosphate-iron deposit, Bafq area, central Iran: Kensington, Australia, University of New South Wales, School of Biological, Earth and Environmental Sciences, unpublished Ph.D. dissertation, 384 p.

Jami, Morteza, Dunlop, A.C., and Cohen, D.R., 2007, Fluid inclusion and stable isotope study of the Esfordi apatite-magnetite deposits, central Iran: Economic Geology, v. 102, p. 1111-1128.

Jasinski, S.M., 2014, Phosphate rock, in Mineral Commodity Summaries 2014: U.S. Geological Survey, p. 118-119.

Klett, T.R., Ulmishek, G.F., Wandrey, C.J., Agena, W.F., and The U.S. Geological SurveyAfghanistan Ministry of Mines and Industry Joint Oil and Gas Resource Assessment Team, 2006, Assessment of undiscovered technically recoverable conventional petroleum resources of Northern Afghanistan: U.S. Geological Survey Open-File Report 2006-1253, 237 p. [Also available at http://pubs.usgs.gov/of/2006/1253/.] 
Klishevich, V.L., Belgovsky, G.L., Vasiliev, D.G., Vytovich, I.I., Biske, Y.S., Kovaleva, N.P., Kraskov, L.N., Krylova, T.N., Leskov, S.A., Mitrofanova, K.V., Panchenko, E.P., Smolno, A.I., Timofeeva, E.A., Vasyuntsova, V.S., and Radyukevicha, N.M., 1990, [Geological map of the USSR, new series, sheet K-(42),(43) Tashkent, Map of pre-Quaternary rocks]: Leningrad, Russian Ministry of Geology, Karpinsky Russian Geological Research Institute (VSEGEI), scale 1:1,000,000. [In Russian.]

Kogarko, L.N., Kononova, V.A., Orlova, M.P., and Woolley, A.R., 1995, Alkaline rocks and Carbonatites of the world; Part two-Former USSR: London, Chapman \& Hall, 226 p.

Levine, R.M., 1997, The mineral industry of Uzbekistan 1996, in Minerals Yearbook 1996: U.S. Geological Survey, 5 p.

MacLeod, Ian, Amorin, Roger, and Valleau, Nicholas, 2003, DAP_-large volume spatial data discovery and distribution over networks: Geosoft White Paper 211-03, accessed December 11, 2013, at http://geosoft.com/media/uploads/resources/white-papers/dap_white_paper_021103.pdf.

Magretova, M.D., Galaktionova, A.B., Shutkova, L.V., and Petrova, N.V., 1982, [Geological map of the USSR, new series, sheet L-(39),(40) Guryev, Map of pre-Quaternary rocks]: Leningrad, Russian Ministry of Geology, Karpinsky Russian Geological Research Institute (VSEGEI), scale 1:1,000,000. [In Russian.]

Mehdilo A., and Irannajad, M., 2012, Mineralogical studies of apatites of Gara-Aghaj deposit from mineral processing viewpoint: Iranian Journal of Crystallography and Mineralogy, v. 20, no. 1, p. 36-25. [In Persian, with English summary.]

Mirakhmedov, M., and Palybekov, A., 1988, Discovery of grainy-detrital phosphorites in southeastern Ushtagan, Kara-Kalpak, ASSR: Zapiski Uzbekistanskogo Otdeleniya Vsesoyuznogo Mineralogicheskogo Obshchestva, v. 41 p. 153-156.

Mirzakhanov, M.K., ed., 1989, Gyeologichyeskaya karta Toorkmyenskoy SSR [Geological map of Turkmenistan]: Ministry of Geology of USSR and Turkmengeologiya, 12 sheets, scale 1:500,000. [In Russian.]

Mitchell, A.H.G., and Garson, M.S., 1981, Deposits formed on passive continental margins, in Mineral deposits and global tectonic settings: London, Academic Press, p. 87-101.

Mokhtari, M.A.A., Zadeh, G.H., and Emami, M.H., 2013, Genesis of iron-apatite ores in Posht-eBadam Block (central Iran) using REE geochemistry: Journal of Earth System Science, v. 122, no. 3, p. 795-807.

Mosier, D.L., 1986a, Descriptive model of upwelling type phosphate deposits, in Cox, D.P., and Singer, D.A., eds., Mineral deposit models: U.S. Geological Survey Bulletin 1693, p. 234.

Mosier, D.L., 1986b, Descriptive model of warm current type phosphate deposits, in Cox, D.P., and Singer, D.A., eds., Mineral deposit models: U.S. Geological Survey Bulletin 1693, p. 237.

Navoi Mining \& Metallurgical Combinat, 2013, Products of Kyzylkum phosphorite complexPhosphorite: Navoi, Uzbekistan, Navoi Mining \& Metallurgical Combinat Web page, accessed September 17, 2013, at http://www.ngmk.uz/en/products/fosfor.

Notholt, A.J.G., 1994, Phosphate rock in developing countries - a review of geology, resources and development, in Mathers, S.J., and Notholt, A.J.G., eds., Industrial minerals in developing countries: British Geological Survey and Association of Geoscientists for International Development, AGID Report Series Geosciences in International Development 18, p. 193-222.

Notholt, A.J.G., Sheldon, R.P., and Davidson, D.F., eds., 1989a, Preface, in Phosphate deposits of the world; Volume 2-Phosphate rock resources: Cambridge, Cambridge University Press, p. xxiii-Xxv. 
Notholt, A.J.G., Sheldon, R.P., and Davidson, D.F., eds., 1989b, Middle East-Introduction, in Phosphate deposits of the world; Volume 2-Phosphate rock resources: Cambridge, Cambridge University Press, p. 312-315.

Orris, G.J., and Chernoff, C.B., 2004, Review of world sedimentary phosphate deposits and occurrences, in Hein J.R., ed., Life cycle of the Phosphoria Formation-From deposition to the postmining environment: Amsterdam, Elsevier, p. 559-573.

Peters, S.D., Ludington, S.D., Orris, G.J., Sutphin, D.M., Bliss, J.D., and Rytuba, J.J., 2007, Preliminary non-fuel mineral resources assessment of Afghanistan: U.S. Geological Survey OpenFile Report 2007-1214 (USGS Afghanistan Project Product No. 157), 2 CD-ROMs. [Also available at http://pubs.usgs.gov/of/2007/1214/.]

Petrova, N.V., and Magretova, M.D., 1987, [Geological map of the USSR, new series, sheet L(40),(41) Kazalinsk, Map of pre-Quaternary rocks]: Leningrad, Russian Ministry of Geology, Karpinsky Russian Geological Research Institute (VSEGEI), scale 1:1,000,000. [In Russian.] Pokryshkin, V.I., 1981, Zakonomernosti razmeshcheniya promyshlennykh mestorozhdeniy fosforitov dokembriya i fanerozoya mira [Distribution regularities of Precambrian and Phanerozoic commercial phosphorite deposits in the world]: All-Union Research Institute for Geology of Foreign Countries, Trudy, v. 38, 205 p.

Popov, V.S., Zakirov, M.Z., and Mirakhmedov, M., 1982, Outlook for the Zarafshan-Pendzhikent phosphate-bearing region in the central part of Central Asia: Zapiski Uzbekistanskogo Otdeleniya Vsesoyuznogo Mineralogicheskogo Obshchestva, v. 35, p. 127-129. [In Russian.]

Pyanovskaya, I.A., Bayakhunova, S.Y., Bukharin, A.K., Bykovsky, Y.K., Galicki, V.V., Mansurov, R.I., Pyatkov, K.K., and Fedorenko, O.A., 1979, [State geological map of the USSR, new series, sheet K-(41),(42) Turkestan, Map of pre-Quaternary rocks]: Leningrad, Russian Ministry of Geology, Karpinsky Russian Geological Research Institute (VSEGEI), scale 1:1,000,000. [In Russian.]

Qorbani, M., and Kani, A., 2005, Mining in Iran; I-Mines and mineral resources, in Yarshater, E., and others, eds., Encyclopaedia Iranica: New York, Columbia University Center for Iranian Studies, accessed January 25, 2014, at http:/www.iranicaonline.org/articles/mining-in-iran-i.

Qureshi, A.A., Khattak, N.U., Sardar, M., Tufail, M., Akram, M., Iqbal, T., and Khan, H.A., 2001, Determination of uranium contents in rock samples from Kakul phosphate deposit, Abbotabad (Pakistan), using fission-track technique: Radiation Measurements, v. 34, p. 355-359.

Qureshi, M.K.A., Ghazi, Shahid, Butt, A.A., and Ahmad, Nazir, 2007, Microfacies analysis and the environmental pattern of the Chichali Formation, Kala Chitta Range, Pakistan: Punjab University Geological Bulletin, v. 42, p. 53-59.

Qureshi, M.J., Tariq, M.A., Abid, Q.Z., and compilers, 1993, Geological map of Pakistan: Pakistan Geological Survey, 4 sheets, scale 1:1,000,000.

Rasulov , U.M., Jr., Fathullaev, G., Muzylev, N.G., and Morozov, S.D., 1990, The age of phosphate deposits in central Kyzylkum: Uzbekiston Geologiya Zhurnali = Uzbekskiy Geologicheskiy Zhurnal, v. 1990 , no. 6 , p. 3-7.

Riggs, S.R., 1980, Tectonic model of phosphate genesis, in Sheldon, R.P., and Burnett, W.C., eds., Fertilizer mineral potential in Asia and the Pacific: Honolulu, Hawaii, East-West Resource Systems Institute, p. 15-190.

Sabiha-Javied, Mehmood, T., Chaudhry, M.M., Tufail, M., and Irfan, N., 2009, Heavy metal pollution from phosphate rock used for the production of fertilizer in Pakistan: Micromedical Journal, v. 91, p. 94-99. 
Salehi, H., 1989, The sedimentary phosphate resources of Iran, in Notholt, A.J.G., Sheldon, R.P., and Davidson, D.F., eds., Phosphate deposits of the world; Volume 2-Phosphate rock resources: Cambridge, Cambridge University Press, p. 323-328.

Shields, Graham, Stille, Peter, and Brasier, M.D., 2000, Isotopic records across two phosphorite giant episodes compared-The Precambrian-Cambrian and the Late Cretaceous-Recent, in Glenn, C.R., Prévot-Lucas, Liliane, and Lucas, Jacques, eds., Marine authigenesis-From global to microbial: Society for Sedimentary Geology (SEPM) Special Publication 66, p. 103-115.

Smolko, A.I., Zheleznov, V.M., Kulesh, A.A., Kuvshinova, I.F., Ryvkin, M.L., and Schultz, S.S., 1976, [Geological map of the USSR, new series, sheet K-(40),(41) Nukus, Map of the preQuaternary rocks]: Leningrad, Russian Ministry of Geology, Karpinsky Russian Geological Research Institute (VSEGEI), scale 1:1,000,000. [In Russian.]

Soleimani, B., 2009, Paleoclimate reconstruction during Pabdeh, Gurpi, Kazhdumi and Gadvan Formations (Cretaceous-Tertiary) based on clay mineral distribution: World Academy of Science, Engineering and Technology, v. 4, p. 351-355.

Stosch, H.-G., Romer, R.L., Daliran, Farahnaz, and Rhede, Dieter, 2011, Uranium-lead ages of apatite from iron oxide ores of the Bafq District, east-central Iran: Mineralium Deposita, v. 46, p. 9-21.

Torab, F.M., 2008, Chemistry and metallogeny of magnetite-apatite deposits of the Bafq Mining District, central Iran: Tehran, Iran, Clausthal University of Technology, Institute of Mineralogy and Mineral Resources, Ph.D dissertation, 131 p.

Tucker, R.D., Belkin, H.E., Schulz, K.J., Peters, S.G., and Buttleman, K.P., 2011 a, Rare earth element mineralogy, geochemistry, and preliminary resource assessment of the Khanneshin carbonatite complex, Helmand Province, Afghanistan: U.S. Geological Survey Open-File Report 2011-1207, 50 p. [Also available at http://pubs.usgs.gov/of/2011/1207/.]

Tucker, R.D., Belkin, H.E., Schulz, K.J., Peters, S.G., Horton, Forrest, Buttleman, Kim, and Scott, E.R., 2012, A major light rare-earth element (LREE) resource in the Khanneshin carbonatite complex, southern Afghanistan: Economic Geology, v. 107, no. 2, p. 197-208.

Tucker, R.D., Peters, S.G., Schulz, K.J., Renaud, K.M., Stettner, W.R., Masonic, L.M., and Packard, P.H., 2011b, Geologic map of the Khanneshin carbonatite complex, Helman Province, Afghanistan, modified from the 1976 original map compilation of V.G. Cheremytsin: U.S. Geological Survey Open-File Report 2011-1244, one sheet, scale 1:10,000. [Also available at http://pubs.usgs.gov/of/2011/1244/.]

Ullah, Nimat, 2006, Geochronological studies of the carbonatite complexes within the Peshawar Plain Igneous Province using fission-track dating technique: Peshawar, Pakistan, National Centre of Excellence in Geology, University of Peshawar, Ph.D. dissertation, 221 p.

Uzbekistan State Committee on Geology and Mineral Resources, 2011, Investment deposits of mining chemical raw material of the Republic of Uzbekistan, Investment potential of hard minerals of Uzbekistan, 6 October, 2011: Tashkent, Uzbekistan, ITE Uzbekistan Web page, accessed February 25, 2013, at http://www.ite-uzbekistan.uz/ITE-ADVERT/List_depositsEng.pdf.

Vachard, D., 1996, Iran, in Martinez-Diaz, Carlos, Granados, L.F., Wagner, R.H., and Winkler Prins, C.F., eds., The Carboniferous of the world; III-The former USSR, Mongolia, Middle Eastern Platform, Afghanistan and Iran: International Union of Geological Science (IUGS) Publication 33, p. 491-521.

Vlasov, N.G., Goretskaya, E.N., Kangro, O.G., Kotelnikov, V.I., and Sharpenok, L.N., 1989, [Geological map of the USSR, new series, sheet J-(42),(43) Novobod, Map of pre-Quaternary rocks]: Leningrad, Russian Ministry of Geology, Karpinsky Russian Geological Research Institute (VSEGEI), scale 1:1,000,000. [In Russian.] 
Vlasov, N.G., Klyushkin, A.V., Kotelnikov, V.I., Koshelev, N.I., Kuharenko, E.A., Medvedev, B.A., Starshinir, D.A., Sharpenok, L.N., Cherner, E.S., and Ektova, L.A., 1992, [Geological map, new series, sheet J-(41),(42) Dushanbe, Map of pre-Quaternary rocks]: Leningrad, Russian Ministry of Geology, Karpinsky Russian Geological Research Institute (VSEGEI), scale 1:1,000,000. [In Russian.]

Wynn, J.C., 1993, Petrophysical assessment of phosphate-A progress report: Annual report of the USGS mission, Kingdom of Saudi Arabia, for the fiscal year 1992, p. 81-86.

Wynn, J.C., 1996, Geophysics applied to phosphate exploration in northern Saudi Arabia [abs.]: Extended Abstract, Proceedings Volume of the Society of Exploration Geophysics Annual International Meeting, Denver, Colo., 10-15 November 1996, 6 p.

Xinjiang Bureau of Geology and Mineral Resources, 1993, Geological map of Xinjiang Uygur Autonomous Region of the People's Republic of China: Beijing, Geological Publishing House, series 1, no. 32, scale 1:1,500,000. [In Chinese and English.]

Yaghubpur, A., Rahimsouri, Y., and Alipour, S., 2007, Mineralogy, geochemistry and genesis of titanium rich rocks of Qara Aqaj area, Urmia, northwest Iran: Iran Journal of Sciences, v. 18, no. 3, p. 269-284.

Yanshin, A.L., 1982, Kisil Kum phosphorite deposits, in Symposium of 5th International Field Workshop and Seminar on Phosphorite: Kunming, China, Geological Publishing House, p. 465-470. 


\title{
Appendix A. Description of Digital Data Files
}

\author{
By Pamela Dunlap
}

\section{Introduction}

Spatially referenced data were developed for use in Esri ArcGIS 10.2 (and higher) software, a geographic information system (GIS). An Esri file geodatabase (Phosphate.gdb) contains two feature classes with descriptive information for possible phosphate-bearing rock units (SAsia_Phos_units) and deposits and occurrences of phosphate (SAsia_Phos_sites), and one table of references cited for deposits and occurrences (Citations). An Esri map document (SAsia_phosphate.mxd) and an Esri file geodatabase feature class of political boundaries for countries in the area (SouthernAsia_countries) are also provided for viewing the data. The spatial data are stored in geographic coordinates using the World Geodetic Survey datum of 1984 (WGS 84). All of these files may be downloaded from the Internet at http://dx.doi.org/10.3133/ofr20151121 as the compressed archive file ofr20151121_gis.zip; the files in the archive are listed and briefly described in table A1.

These databases can be queried in a GIS to portray distribution, geologic setting, and mineralization potential of phosphate in southern Asia.

\section{Deposits and Occurrences}

The feature class SAsia_Phos_sites contains vector data (points) for 447 deposits and occurrences with phosphate mineralization. Attributes include site and alternate site names, site and producer status, location coordinates, country and state or province, age, commodities, mineralogy, host rocks, and abbreviated source references. Attributes are defined in the metadata which are both embedded in the feature class and provided in an Adobe Acrobat portable document format file (SAsia_Phos_sites_metadata.pdf). The geodatabase table Citations provides full reference citations and Web sites (if available) for the abbreviated source references listed for each site in the feature class SAsia_Phos_sites.

Table A1. Description of digital data files in the compressed archive file ofr20151121_gis.zip.

\begin{tabular}{|c|c|}
\hline File name & File description \\
\hline Citations & $\begin{array}{l}\text { Standalone table of full references (and their URLs, if available) for source } \\
\text { literature cited in the feature class SAsia_Phos_sites. }\end{array}$ \\
\hline SAsia_Phosphate & $\begin{array}{l}\text { Feature dataset for phosphate resource data in geographic coordinates; } \\
\text { includes the feature classes SAsia_Phos_units and SAsia_Phos_sites. }\end{array}$ \\
\hline SAsia_Phos_sites_Citations & $\begin{array}{l}\text { Relationship class that manages the association between objects in the } \\
\text { feature class SAsia_Phos_sites to objects in the table Citations. }\end{array}$ \\
\hline SouthernAsia_countries & $\begin{array}{l}\text { Feature class (polygons) of countries in the study area and surrounding } \\
\text { region; extracted from a GIS of country boundaries and shorelines } \\
\text { maintained by the U.S. Department of State (2009). }\end{array}$ \\
\hline
\end{tabular}




\begin{tabular}{|c|c|}
\hline File name & File description \\
\hline \multicolumn{2}{|r|}{ Esri Map Document } \\
\hline SAsia_phosphate.mxd & $\begin{array}{l}\text { ArcMap document used for querying and viewing data in a map format and } \\
\text { for producing customized maps. }\end{array}$ \\
\hline \multicolumn{2}{|c|}{ Esri layer files for symbolizing attributes of the feature classes } \\
\hline Deposit Type.lyr & Sites symbolized for type of phosphate deposit. \\
\hline Site Status.lyr & $\begin{array}{l}\text { Sites symbolized for site status (deposit or occurrence, queried where } \\
\text { uncertain). }\end{array}$ \\
\hline Grouped map units.lyr & $\begin{array}{l}\text { Map units symbolized by generalized groupings of rock units based upon } \\
\text { geologic age. }\end{array}$ \\
\hline Maximum mineralization age.lyr & Sites symbolized for maximum geologic age of phosphate mineralization. \\
\hline Site Name.lyr & Sites symbolized for name of deposit or occurrence. \\
\hline Map Units.lyr & Map units symbolized by unit description based upon geologic scale. \\
\hline \multicolumn{2}{|c|}{ Adobe Acrobat portable document format (PDF) files } \\
\hline SAsia_Phos_units_metadata.pdf & Metadata for File Geodatabase feature class SAsia_Phos_units. \\
\hline SAsia_Phos_sites_metadata.pdf & Metadata for File Geodatabase feature class SAsia_Phos_sites. \\
\hline SAsia_Phos_sites_references_metadata.pdf & $\begin{array}{l}\text { Metadata for File Geodatabase standalone table Citations for full reference } \\
\text { information for abbreviated citations used in File Geodatabase feature } \\
\text { class SAsia_Phos_sites. }\end{array}$ \\
\hline
\end{tabular}

\section{Phosphate-Bearing Rock Units}

The feature class SAsia_Phos_units contains vector data (polygons) for rock units that may contain phosphate mineralization. The data were compiled from country-wide and regional geologic maps by Abdullah and Chmryiov (1977), Bikbaeva (1994), Bureau of Geology and Mineral Resources of Xinjiang Uygur Autonomous Region (1993), Doebrich and Wahl (2006), Huber (1978), Klishevich and others (1990), Magretova and others (1982), Mirzakhanov (1989), Petrova and Magretova (1987), Pyanovskaya and others (1979), Qureshi and others (1993), Smolko and others (1976), Vlasov and others (1989), and Vlasov and others (1992). Attributes are defined in the metadata which are both embedded in the feature class and provided in an Adobe Acrobat portable document format file (SAsia_Phos_units_metadata.pdf). Map units were initially compiled by age; this resulted in a primary set of 32 units represented by the fields Unit_label, Unit_age, and Unit_desc (for map unit label, age, and description, respectively) in the attribute table. These primary map units were then combined to produce a generalized, secondary set of 16 map units represented by the fields Grp_label, Grp_age, and Grp_group_desc (for generalized map unit label, age, and description, respectively). Attributes are defined in the metadata which are both embedded in the feature class and provided in an Adobe Acrobat portable document format file (SAsia_Phos_units_metadata.pdf).

\section{Map Document Files and Layer Files}

The map file, SAsia_phosphate.mxd, displays various predefined views of the spatial databases, in addition to source references from the standalone table Citations that is attached and hyperlinked to source information online. Bookmarks are set to provide both a macroregional view of southern Asia and a regional view of Afghanistan. Esri layer files that store the path to a source dataset and predefined map symbols for the data can be selected to view the data by site type and by the 
secondary set of generalized map units. Layer files generated for the feature classes are listed and described in table A1.

\section{Summary}

GIS data for phosphate in Afghanistan and the vicinity consists of an Esri file geodatabase and associated nonspatial files. A table of source references for phosphate deposits and occurrences is linked to the features for easy viewing with an ArcMap map document using ArcGIS 10. Definitions of the fields and values in the spatial databases are provided in the metadata.

These databases can be queried to produce a variety of interpretive geologic maps and used to conduct reconnaissance exploration for phosphate in the area.

\section{References Cited}

Abdullah, Sh., and Chmyriov, V.M., eds., 1977, Map of mineral resources of Afghanistan: Kabul, Afghanistan, Ministry of Mines and Industries, Department of Geological and Mineral Survey, V/O Technoexport USSR, scale: 1: 500,000.

Bikbaeva, B.I., 1994, [Geological map of the Russian Federation, new series, sheet K-(39),(40) Krasnovodsk, Map of the pre-Quaternary rocks]: Leningrad, Russian Ministry of Geology, Karpinsky Russian Geological Research Institute (VSEGEI), scale 1:1,000,000. [In Russian.] Bureau of Geology and Mineral Resources of Xinjiang Uygur Autonomous Region, 1993, Geological map of Xinjiang Uygur Autonomous Region of the People's Republic of China: Beijing, Geological Publishing House, series 1, no. 32, scale 1:1,500,000. [In Chinese and English.]

Doebrich, J.L., and Wahl, R.R., comps., 2006, Geologic and mineral resource map of Afghanistan (ver.

2): U.S. Geological Survey Open-File Report 2006-1038, scale 1:850,000, available at http://pubs.usgs.gov/of/2006/1038/.

Huber, H., comp., 1978, Geological map of Irān: National Iranian Oil Company, 6 sheets, scale $1: 1,000,000$.

Klishevich, V.L., Belgovsky, G.L., Vasiliev, D.G., Vytovich, I.I., Biske, Y.S., Kovaleva, N.P., Kraskov, L.N., Krylova, T.N., Leskov, S.A., Mitrofanova, K.V., Panchenko, E.P., Smolno, A.I., Timofeeva, E.A., Vasyuntsova, V.S., and Radyukevicha, N.M., 1990, [Geological map of the USSR, new series, sheet K-(42),(43) Tashkent, Map of pre-Quaternary rocks]: Leningrad, Russian Ministry of Geology, Karpinsky Russian Geological Research Institute (VSEGEI), scale 1:1,000,000. [In Russian.]

Magretova, M.D., Galaktionova, A.B., Shutkova, L.V., and Petrova, N.V., 1982, [Geological map of the USSR, new series, sheet L-(39),(40) Guryev, Map of pre-Quaternary rocks]: Leningrad, Russian Ministry of Geology, Karpinsky Russian Geological Research Institute (VSEGEI), scale 1:1,000,000. [In Russian.]

Mirzakhanov, M.K., ed., 1989, Геологическая карта Туркменской CСР [Geological map of Turkmenistan]: Ministry of Geology of USSR and Turkmengeologiya, 12 sheets, scale 1:500,000. [In Russian.]

Petrova, N.V., and Magretova, M.D., 1987, [Geological map of the USSR, new series, sheet L(40),(41) Kazalinsk, Map of pre-Quaternary rocks]: Leningrad, Russian Ministry of Geology, Karpinsky Russian Geological Research Institute (VSEGEI), scale 1:1,000,000. [In Russian.] Pyanovskaya, I.A., Bayakhunova, S.Y., Bukharin, A.K., Bykovsky, Y.K., Galicki, V.V., Mansurov, R.I., Pyatkov, K.K., and Fedorenko, O.A., 1979, [State geological map of the USSR, new series, sheet K-(41),(42) Turkestan, Map of pre-Quaternary rocks]: Leningrad, Russian Ministry of 
Geology, Karpinsky Russian Geological Research Institute (VSEGEI), scale 1:1,000,000. [In Russian.]

Qureshi, M.J., Tariq, M.A., Abid, Q.Z., and compilers, 1993, Geological map of Pakistan: Pakistan Geological Survey, 4 sheets, scale 1:1,000,000.

Smolko, A.I., Zheleznov, V.M., Kulesh, A.A., Kuvshinova, I.F., Ryvkin, M.L., and Schultz, S.S., 1976, [Geological map of the USSR, new series, sheet K-(40),(41) Nukus, Map of the preQuaternary rocks]: Leningrad, Russian Ministry of Geology, Karpinsky Russian Geological Research Institute (VSEGEI), scale 1:1,000,000. [In Russian.]

U.S. Department of State, 2009, Small-scale digital international land boundaries (SSIB)—Polygons, beta edition 1, in Boundaries and sovereignty encyclopedia (B.A.S.E.): U.S. Department of State, Office of the Geographer and Global Issues.

Vlasov, N.G., Goretskaya, E.N., Kangro, O.G., Kotelnikov, V.I., and Sharpenok, L.N., 1989, [Geological map of the USSR, new series, sheet J-(42),(43) Novobod, Map of pre-Quaternary rocks]: Leningrad, Russian Ministry of Geology, Karpinsky Russian Geological Research Institute (VSEGEI), scale 1:1,000,000. [In Russian.]

Vlasov, N.G., Klyushkin, A.V., Kotelnikov, V.I., Koshelev, N.I., Kuharenko, E.A., Medvedev, B.A., Starshinir, D.A., Sharpenok, L.N., Cherner, E.S., and Ektova, L.A., 1992, [Geological map, new series, sheet J-(41),(42) Dushanbe, Map of pre-Quaternary rocks]: Leningrad, Russian Ministry of Geology, Karpinsky Russian Geological Research Institute (VSEGEI), scale 1:1,000,000. [In Russian.] 